\title{
A Inspetoria de Monumentos Nacionais do Museu Histórico Nacional e a proteção de monumentos em Ouro Preto (1934-1937)
}

The Inspetoria de Monumentos Nacionais of the Museu Histórico Nacional and the preservation of OuroPreto's monuments (1934-1937)

\section{ALINE MONTENEGRO MAGALHÃES'}

Universidade Federal do Rio de Janeiro / Rio de Janeiro, RJ, Brasil

RESUMO: O presente artigo é dedicado à análise das ações de valoração e defesa da cidade de Ouro Preto levadas a cabo por Gustavo Barroso, então diretor do Museu Histórico Nacional $(M H N)$, entre as décadas de 1920 e 1930. Compreendendo essas ações como parte de um projeto de escrita da história nacional que teve a antiga capital de Minas Gerais como principal referência, o artigo procura identificar os percursos que levaram ao reconhecimento oficial da cidade como Monumento Nacional, em 1933, e a atuação de Barroso nesse processo. Em seguida, estuda as restaurações de monumentos da antiga Vila Rica realizadas sob a responsabilidade de Barroso, especialmente as implementadas por meio da Inspetoria de Monumentos Nacionais (IMN) que funcionou como um departamento do MHN entre 1934 e 1937. Além de caracterizar o regulamento e as práticas desse órgão, identificando os agentes envolvidos em suas atividades, problematiza seu esquecimento na memória histórica sobre as políticas públicas de preservação do patrimônio no Brasil.

PALAVRAS-CHAVE: Museu Histórico Nacional. Inspetoria de Monumentos Nacionais (19341937). Ouro Preto - MG. Gustavo Barroso (1888-1959).

\begin{abstract}
1. Historiadora. Doutora e mestre em História Social pelo PPGHIS/UFRJ. Técnica em História no Museu Histórico Nacional, onde atua na área de pesquisa e edição. Docente no curso de MBA de Gestão de Museus, da Universidade Cândido Mendes, ministrando a disciplina: Produção do conhecimento dentro de museus desde fevereiro de 2017. É líder do grupo de pesquisa certificado no CNPq, "Escritas da história em museus: objetos, narrativas e temporalidades" e pesquisadora associada do Proarq/UFRJ. E-mail:<alinemontenegro@ gmail.com>.
\end{abstract}


3. No início de sua carreira como jornalista e escritor, Gustavo Barroso assinava suas obras e contribuições para a imprensa com o pseudônimo João do Norte, unindo a simplicidade de um nome com a referência a um lugar de origem, a partir do qual cria a identidade de um homem que fala de seu povo e de sua terra. Ao ser questionado sobre a escolha de seu pseudônimo, Barroso alegou que se tratava de uma forma de se proteger, pois publicava artigos nos jornais cearenses da oposição. "Ora, já havia João do Rio, havia igualmente João Luso. [...] Era natural que me ocorresse a ideia de assinar João do Norte." Cf.: Por que escolheu o pseudônimo? (1949).

4. Ver Gustavo Barroso (1941).

5. Ainda no Ceará, além de criar sua própria revista humorística, $O$ Garoto, sendo responsável pela redação e pelas ilustrações, Barroso também colaborou para jornais locais e da então capital da República, como $O$ Malho e Tico-tico. Neste publicou, em fascículos, entre 1908 e 1909 , sua fábula "O anel mágico", com desenhos de próprio punho.
ABSTRACT: This article analyzes the actions of valorization and defense of Ouro Preto carried out by Gustavo Barroso, as director of the National Historical Museum, between the decades of 1920 and 1930. Understanding these actions as part of a writing project of history which had the old capital of Minas Gerais as the main reference, seeks to identify the paths towards the city's official recognition as a National Monument in 1933 and to know Barroso's role in that process. After that, it studies the restorations of monuments of old Vila Rica carried out under Barroso's responsibility, especially those performed through the National Monuments Inspection (IMN), which was a department of the MHN between 1934 and 1937. In addition to characterizing the regulations and the practices of this department, identifying the agents involved in its activities, questions its omission in the historical memory about the public policies of preservation of the heritage in Brazil.

KEYWORDS: Museu Histórico Nacional. Inspetoria de Monumentos Nacionais (1934-1937). Ouro Preto-MG. Gustavo Barroso (1888-1959).

Esse amor de nossas coisas fez-me voltar várias vezes a Ouro Preto e pregar sempre a necessidade de tornar aquela cidade uma como cidade sagrada do Brasil, defendendo dos insultos do tempo e protegendo da tolice dos homens a soberba floração dos seus monumentos.

João do Norte, $1928^{2}$

\section{INTRODUÇÃO}

João do Norte ${ }^{3}$ era o pseudônimo com o qual Gustavo Barroso assinava suas colaborações para a imprensa após ter migrado do Ceará, sua terra natal, para o Rio de Janeiro, em 1910. Em suas memórias, ele relata a mudança para a então capital federal como uma saída para perseguições políticas que sofria quando ainda estudava Direito em Fortaleza. ${ }^{4}$ Entretanto, mais do que uma fuga provocada por circunstâncias adversas, Barroso projetava seguir os passos de conterrâneos que fizeram esse movimento anteriormente e lograram êxito nas letras, na imprensa ou na política, como Capistrano de Abreu e Clóvis Beviláqua. Então, além de concluir os estudos, investiu na continuidade de sua carreira jornalística, ${ }^{5}$ ingressando no Jornal do Commércio em 1911. 
A estreia de Barroso na literatura ocorreu com o livro Terra de Sol, publicado em 1912 e com forte caráter nostálgico da terra natal. A obra foi dedicada, entre outros, a Coelho Neto, que o acolheu em seus salões literários, incentivando-o a escrever sobre o Ceará. Casou-se com Antonieta Laboriau em 1914, tendo Pinheiro Machado como um de seus padrinhos. Nesse mesmo ano, após assumir o cargo de Secretário do Interior do Ceará, nomeado por seu primo, o coronel Benjamin Liberato Barroso, então presidente do estado, deu início à sua efêmera carreira política como deputado federal pelo Partido Republicano Conservador. Com mandato findo em 1918, e não conseguindo se reeleger, passou a dedicar-se integralmente às atividades intelectuais, como a colaboração para os principais periódicos da cidade do Rio de Janeiro, a exemplo da Revista Fon-Fon-para a qual colaborava desde 1911 , passando a dirigir a redação em 1916 - e a escrita de livros sobre os mais variados assuntos e gêneros, como folclore, história, sociologia, fábulas, contos e romance. Foi membro das principais agremiações culturais do país e do exterior, como a Academia Brasileira de Letras (ABL), na qual ingressou em 1923 com 35 anos, o Instituto Histórico e Geográfico Brasileiro (IHGB), no qual tornou-se sócio em 1931, além da Academia de Ciências de Lisboa e da Sociedade de História Argentina.

Em 1919, Barroso acompanhou o então senador Epitácio Pessoa, chefe da delegação brasileira, à Conferência de Paz de Versalhes. Ao se tornar presidente da República, Epitácio Pessoa criou o Museu Histórico Nacional (MHN) em 1922, nomeando Barroso como diretor. Esse já havia escrito artigos para a imprensa pregando a necessidade de um museu "destinado a guardar relíquias do nosso passado, cultuando a lembrança dos nossos grandes feitos e dos nossos grandes homens". ${ }^{\circ}$ Manteve-se no cargo até sua morte, com um breve interregno entre 1930 e 1932, quando ficou afastado em represália por seu apoio a Júlio Prestes nas eleições em que Getúlio Vargas saiu derrotado.

Em 1928, quando escreveu "Ouro Preto, cidade Sagrada", demonstrando sua postura romântica frente à cidade e seus vestígios dos tempos coloniais, Gustavo Barroso integrava um grupo de intelectuais que chamava a atenção da sociedade e das autoridades para a necessidade de proteção dos edifícios históricos e artísticos nacionais, entre os quais destacavam-se o médico José Marianno Filho, defensor do estilo neocolonial de arquitetura, e Alceu Amoroso Lima, intelectual que, em 1922, aderiu ao movimento modernista. Por meio da imprensa, esses homens de letras procuravam divulgar a importância dos monumentos urbanos, especialmente os da cidade de Ouro Preto, como representativos de uma "autêntica" nacionalidade. Vivia-se um período de busca pela essência do que era o Brasil, num processo de construção da identidade nacional na república então recentemente instituída. 
7. Ver Lúcia Lippi Oliveira (1990).

8. Cf. Lúcia Lippi Oliveira (1990, p. 24)

9. Ver Lilia Moritz Schwarcz (2002).
Lúcia Lippi de Oliveira 7 fez um mapeamento das correntes de pensamento que então concorriam, na arena política e cultural do país, para definir a ideia do que constituiria a autêntica nação brasileira. Entre elas, havia as que tendiam a tratar o tema a partir do Estado e de sua forma de governo, dividindo-se em dois grupos principais: os monarquistas e os republicanos. Os primeiros avaliavam positivamente os períodos colonial e imperial, valorizando nossas tradições, consideradas como fruto da ação colonizadora portuguesa aliada à ação civilizatória da lgreja Católica. Já os republicanos viam no regime instaurado em 1889 uma ruptura necessária com o passado português, consubstanciado no regime monárquico. Identificados com o modelo de república federativa, viam os Estados Unidos da América como um exemplo a ser seguido. Dois autores podem representar essas duas vertentes. "Eduardo Prado, ao negar as virtudes atribuídas ao republicanismo norte-americano e apresentar uma sofisticada defesa do regime monárquico, foi tomado como referência da vertente mais conservadora do nacionalismo. Raul Pompéia, por sua vez, congrega e consagra o argumento em favor do nacionalismo republicano, em sua luta marcada por forte conteúdo antilusitano". 8

Além dessas correntes fundamentadas no tipo de regime político, outras versões do nacionalismo foram formuladas nesse período. Destacam-se a dos cientificistas que não acreditavam no futuro do país, uma vez que a miscigenação, segundo eles, corrompia os alicerces da nação, ${ }^{9}$ e a dos ufanistas edênicos, que, tendo Afonso Celso como principal representante, cultuavam o orgulho patriótico a partir das condições naturais da terra, ignorando aspectos políticos e econômicos.

A década de 1920 foi marcada por linhas de pensamento sobre a nação que buscavam romper com essas concepções até então em disputa. Voltavam-se para o passado colonial para identificar as raízes da sociedade brasileira, compreendendo a miscigenação como um aspecto positivo da nação e a valorização do povo como genuína expressão da brasilidade. A noção de povo foi associada às camadas mais pobres da população, principalmente as oriundas do interior do Brasil. Essa formulação partiu da premissa de que os que não viviam no litoral, sob a influência de "estrangeirismos", conservavam a originalidade do ser brasileiro, a exemplo do Jeca Tatu, personagem criado por Monteiro Lobato. Nessa perspectiva, os estudos sobre folclore foram fundamentais para compreender essa complexa formação social, sendo a cultura o principal instrumento para forjar uma integração entre campo e cidade, entre popular e erudito.

$\bigcirc$ grupo de intelectuais que participara da Semana de Arte Moderna em 1922 tornou-se um dos principais agentes dessa busca da autêntica nação brasileira por intermédio da cultura e das artes identificadas no passado remoto 
que teria sido preservado no interior do país. Apesar de o movimento modernista ter se caracterizado em 1922 pelo combate ao passado e pela elaboração de uma estética adequada à vida moderna, vários de seus integrantes acabaram, nos anos seguintes, recorrendo ao valor da autenticidade visando ao conhecimento da essência do ser brasileiro a partir de um forte conteúdo estético. Entre aqueles modernistas da Semana que passaram a se preocupar com essa questão destacamse Oswald de Andrade e Mário de Andrade, aos quais se somaram outros como Manuel Bandeira e Tarsila do Amaral.

No campo político e cultural, Barroso costumava se posicionar entre os monarquistas conservadores a favor das permanências e contrariando as correntes modernas de pensamento. Sua atuação política como deputado federal seguia a tendência de reafirmação das tradições do Estado, dos militares e das oligarquias. Apresentou projeto de lei dando a denominação de "Dragões da Independência" ao $1^{\circ}$ Regimento de Cavalaria de Guardas, destinado à proteção da Presidência da República, estabelecendo para a nova unidade do Exército o uniforme da antiga Guarda de Honra do Imperador D. Pedro I. Outros temas recorrentes em sua atuação foram a seca do Nordeste, o banditismo social (cangaço), a proteção aos índios e o controle da imigração.

Na área cultural, Barroso destacou-se como um dos principais estudiosos do folclore brasileiro dedicados à definição de uma essência nacional no sertão. Seus escritos eram marcados por um forte caráter nostálgico, ligado à sua vivência no interior - não como um dos sertanejos que analisava, mas como um letrado atento às pessoas e às práticas "típicas" do lugar, sobre as quais atribuía a si autoridade científica para identificar, descrever e classificar. ${ }^{10}$ Procurava registrar no papel aspectos da tradição oral vistos como ameaçados em meio às mudanças impostas pelo progresso. Em contraponto à obra folclorista - e ao mesmo tempo em complementação -, fazendo uma clara distinção entre o povo e a nação, ${ }^{11}$ Barroso dedicou-se à História, especialmente à frente do Museu Histórico Nacional. Aproximava suas concepções das dos monarquistas, que viam o Brasil como continuidade das tradições europeias nos trópicos, enfatizando fatos militares e o papel civilizatório da monarquia, da aristocracia e da lgreja Católica. Com base nessa idealização da nação, lutava contra o descaso devotado aos vestígios do passado que, abandonados, destruídos por reformas urbanas ou vendidos para fora do país em comércio de antiguidades, ameaçavam o culto da saudade. ${ }^{12}$

objetivo do presente artigo é analisar as ações de valoração e defesa de Ouro Preto levadas a cabo por Gustavo Barroso, então diretor do Museu Histórico Nacional, entre as décadas de 1920 e 1930. Compreendendo essas ações como parte de um projeto de escrita da história ${ }^{13}$ nacional que teve a antiga
10. Ver Afonsina Maria Augusto Moreira (2006)

11. Ver Daniel Pécault (1990).

12. Cf. João do Norte (1912).

13. Aqui a escrita da história é compreendida como uma operação que articula um lugar social, práticas disciplinares e a produção de uma narrativa, conforme análise do ofício do historiador realizada por Michel de Certeau (2000). Entretanto, tratava-se da produção de uma narrativa histórica não convencional sobre o Brasil, fundamentada em práticas colecionistas e de defesa dos monumentos arquitetônicos, muito caras à tradição antiquária do século XVII, conforme analisaram Stephen Bann (1994), Françoise Choay (2001) e Manoel Luiz Salgado Guimarães (2007). 
14. Inicialmente chamada Cidade de Minas.

15. Ver Mário Roberto Bonomo (1998).

16. Ver Reinhart Koselleck (2014, p. 23).

17. Ver Mário Roberto Bonomo (1998).

18. Ver José Murilo Carvalho (1990, p. 55-73).

19. Segundo Bonomo, a obra de Joaquim Furtado de Menezes, A religião em $\mathrm{Ou}$ ro Preto, bem como a de Diogo de Vasconcelos, Arte em Ouro Preto, ambas escritas especialmente para a ocasião, foram de fundamental importância para a valorização do barroco, com destaque para a qualidade da arte de Aleijadinho. Esse argumento esteve presente nas posteriores campanhas de defesa dos remanescentes arquitetônicos da cidade. Ver Mário Roberto Bonomo (1998, p. 108).

20. Cf. Mário Roberto Bonomo (1998, p. 107). capital de Minas Gerais como principal referência, procura identificar os percursos que levaram ao reconhecimento oficial da cidade como Monumento Nacional, em 1933, e a atuação de Barroso nesse processo. Em seguida, estuda as restaurações de monumentos da antiga Vila Rica realizadas sob a responsabilidade de Barroso, especialmente as implementadas pela Inspetoria de Monumentos Nacionais (IMN), que funcionou como um departamento do MHN entre 1934 e 1937. Além de caracterizar o regulamento e as práticas desse órgão, identificando os agentes envolvidos em suas atividades, problematiza seu esquecimento na memória histórica sobre as políticas públicas de preservação do patrimônio no Brasil.

\section{OURO PRETO NO CENTRO DAS ATENÇÕES}

Ouro Preto passou a receber atenção em nível nacional após perder a antiga centralidade política regional, com a entrega de seu posto de capital de Minas Gerais a uma cidade recém-construída, Belo Horizonte. ${ }^{14}$ Eclesiásticos, políticos e intelectuais ${ }^{15}$ voltaram seus olhos para a cidade, enaltecendo suas características históricas e artísticas que remetiam ao período colonial, precariamente mantidas entre outras razões, por não terem sofrido com as obras de modernização e embelezamento por quais passaram grandes centros urbanos como Salvador e Rio de Janeiro a partir da década de 1900.

Em meio às rupturas sentidas com as mudanças republicanas, que não se restringiram à criação da nova capital para Minas, embebida dos propósitos de civilização e progresso, buscava-se construir elos com o passado. Estava em jogo uma espécie de reconstituição de um continuum entre a experiência adquirida e a expectativa daquilo que estava por vir. ${ }^{16}$ Alguns, como representantes do clero e políticos mineiros, com o intuito de recuperar prestígios perdidos; ${ }^{17}$ outros, como autoridades e intelectuais, à procura de referenciais para a construção de uma identidade nacional afinada com o novo regime. Tiradentes já havia sido alçado a herói republicano em finais do XIX. ${ }^{18} \mathrm{~A}$ partir de então, não tardou para que o palco da Inconfidência Mineira fosse visto como a síntese da brasilidade, processo que teve como um dos marcos iniciais a comemoração do bicentenário da cidade, em 1911 , com a valorização do século XVIII e a exaltação de Aleijadinho. ${ }^{19} \mathrm{O}$ evento, organizado pelo governo de Minas Gerais, sem grandes protagonismos do poder municipal, teria em "seu extenso programa o propósito de mostrar o importante papel da cidade, como lugar da memória histórica, de modo a exorcizar o trauma causado pela mudança da capital" ${ }^{20}$ Processo semelhante viveu a cidade do Rio de Janeiro quase cinquenta anos depois, com a perda de 
seu posto de capital federal para outra cidade recém-construída, Brasília. Segundo Maria Isabel Ribeiro Lenzi:

O que alguns intelectuais e a imprensa carioca tentavam construir era a ideia de que o Rio continuaria a ser a capital cultural do Brasil. Se Brasília era a Novacap, o Rio de Janeiro sempre seria a Belacap. Mais que isso, os eruditos do IHGB queriam apontar o valor da tradição na cidade do Rio de Janeiro. Queriam mostrar que a cidade ainda estava investida de capital simbólico. ${ }^{21}$

A cidade do Rio de Janeiro apostou exatamente naquilo que Ouro Preto valorizou ao perder sua centralidade regional: beleza e tradição. Mas, se as comemorações de 1911 tiveram sua repercussão limitada a Minas Gerais, ${ }^{22}$ é possível afirmar que foi um passo significativo no caminho do reconhecimento da cidade como o lugar da história e da arte genuinamente nacionais. Foi o que se viu dez anos depois, com a proximidade das comemorações do centenário da Independência.

Entre finais de 1921 e princípio de 1922, membros do Instituto Histórico e Geográfico Brasileiro (IHGB), liderados pelo secretário Jonatas Serrano, solicitaram ao presidente Epitácio Pessoa a proteção de edificações de Ouro Preto relacionadas à Inconfidência Mineira, então considerada precursora da Independência e da República. Por essa razão, nada mais elucidativo do que defender os marcos desse acontecimento na cidade onde ocorreu. Tratava-se também de uma forma de reafirmar os valores que colocavam Minas Gerais na disputa entre os principais estados da federação, pelo reconhecimento como lugar origem da nação centenária. Conforme análise de Marly Mota, tratava-se da defesa do regional como síntese do nacional. Lideranças do Rio de Janeiro por exemplo, reivindicavam o título para a cidade baseados na ideia de que a vinda e a instalação do Estado português lançaram as bases do Estado Nacional e de sua vocação como capital, centro administrativo e cultural do país. Por sua vez, as elites dirigentes de São Paulo evocavam o pioneirismo e a bravura dos bandeirantes para garantir sua legitimação como construtor do Brasil a partir do desbravamento e da interiorização das bandeiras, o que dava sentido ao fato de ter se tornado o principal polo econômico do País. Já em Minas Gerais, apostava-se na sua localização geográfica interiorana, capaz de preservar a autenticidade do ser brasileiro, livre do cosmopolitismo litorâneo. Entretanto, não foi a capital, Belo Horizonte, a referência das formulações da identidade mineira como representação da nacionalidade, mas sim Ouro Preto, palco da Inconfidência Mineira. ${ }^{23}$ Daí a atenção dada à cidade em iniciativas como a do $\Perp H G B$, que mobilizou seu presidente, conde de Afonso Celso, filho do Visconde de Ouro Preto, a encaminhar o assunto ao
21. Cf. Maria Isabel Ribeiro Lenzi (2015, p. 280).

22. Ver Mário Roberto Bonomo (1998, p. 108-109).

23. Ver Marly Silva da Motta (1992, p. 79-103). 
24. Cf. Afonso Celso (1921), grifo nosso.

25. Ver Alois Riegl (2013, p. 34-42).

26. Sobre a valoração dos monumentos como relíquia, ver Françoise Choay (2001, p. 24).

27. Cf. Ministério da Justiça e Negócios Interiores (1922).

28. No lugar foi construída uma escola em estilo neocolonial. presidente da República, redigindo uma carta, na qual reproduziu as considerações de Jonatas Serrano, recém-chegado de uma viagem a Ouro Preto:

Ouro Preto, a Cidade Inconfidente, é um desses raros sítios a que o progresso [...] as obras de melhoramento, ainda não lograram tirar o encanto do cenário antigo, dos aspectos pitorescos e característicos da era colonial.

Tudo ali são recordações do século XVIII, dos mártires da Inconfidência, do abnegado precursor do ideal republicano [...] Assim, nas vésperas do primeiro centenário da Independência, vem o Instituto Histórico para esclarecimento do espírito de V. Ex [...] a fim de que se envidem eficazes esforços e sejam tomadas urgentes medidas capazes de salvar da próxima ruína e total desaparecimento a casa de Marília e os demais edifícios estreitamente vinculados à história da Inconfidência. ${ }^{24}$

A carta de Afonso Celso reafirma a preocupação de Jonatas Serrano com os edifícios que diziam respeito à Inconfidência Mineira e seus protagonistas. Tal preocupação fundamentava-se na ideia de monumento histórico do século XIX, segundo a qual - com base nas considerações de Alois Rieg ${ }^{25}$ - as construções selecionadas para ação protetora são compreendidas como documento de uma produção historiográfica científica. No caso em tela, os remanescentes da Inconfidência Mineira parecem ganhar áurea de relíquia ao serem cultuados por sua vinculação direta com a ação individual dos "heróis", 26 especialmente de Tiradentes.

O assunto foi levado para a Comissão Executiva do Centenário da Independência, que deveria tomar as devidas providências. A Comissão iniciou seu trabalho pedindo aos pesquisadores do IHGB informações minuciosas sobre:

$1^{\circ}$ a quem pertencem atualmente a Casa de Marília, a dos Inconfidentes, a dos Contos, a de Cláudio Manoel e outros edifícios vinculados à Inconfidência.

$2^{\circ}$ em quanto importaria, aproximadamente, a despesa com a aquisição dos que sejam próprios particulares.

$3^{\circ}$ qual o local exato onde existiu a Casa de Tiradentes, afim [sic] de se promover a colocação de uma lápide ou placa comemorativa.

De posse das informações necessárias, a Comissão do Centenário, em cumprimento à determinação do Sr. Presidente da República, poderá sugerir as medidas. ${ }^{27}$

A pesquisa não foi nada animadora para os que pretendiam preservar os marcos da Inconfidência em Ouro Preto. A Casa de Marília, que pertencia aos frades franciscanos, havia sido comprada pelo Ministério da Guerra, a fim de ser demolida e dar lugar a um quartel. ${ }^{28}$ A chácara conhecida como "dos Inconfidentes" foi comprada pelo senador Paulo de Frontin por um preço considerado insignificante 
e suas intenções para com o imóvel eram desconhecidas. A Casa dos Contos pertencia à União e lá funcionava a Agência dos Correios, sendo também moradia do agente Candido Eloy Tassara de Pádua. A Casa de Gonzaga, também da União, estava alugada para os frades franciscanos desde quando estes venderam a Casa de Marília. A casa de Cláudio Manoel da Costa, que, logo após a Inconfidência, passou a ser de Diogo Pereira Ribeiro de Vasconcelos, ${ }^{29}$ estava na ocasião sob posse da família do Dr. Marciano Pereira Ribeiro, que a recebera de herança. No local onde se encontrava a residência de Tiradentes, havia uma casa em ruínas, construída logo após a Independência e doada à Câmara Municipal pelo senador Virgílio de Mello Franco, em cumprimento à intenção do Dr. Afonso Arinos, a quem pertenceu originalmente. Ao final das informações, há referência à necessidade de restauração dos templos, vistos como os mais preciosos de Minas, como a lgreja de São Francisco de Assis.

A resolução final da comissão foi solicitar que a Câmara Municipal de Ouro Preto procedesse à demolição da casa em ruínas para que no local fosse erigida uma lápide em homenagem ao "Mártir da Inconfidência":

1789

Libertas que sera Tamen

Neste local existiv a casa do protomartyr da Independência Joaquim José da Silva Xavier, o Tiradentes, que sacrificou a vida por ter sonhado com a liberdade da pátria sendo executado em 21 de abril de 1792. Em homenagem à sua memória o Governo da República e do Estado de Minas fizeram erigir esta lápide por ocasião do $1^{\circ}$ centenário da Independência do Brasil. ${ }^{30}$

É possível que a placa não tenha sido colocada no local. Atualmente, a Associação Comercial de Ouro Preto ocupa o prédio que foi edificado em 1934, no lugar onde existiu a casa de Tiradentes. Os comerciantes compraram o terreno, onde havia uma casinha em ruínas e uma área, para construir a sede da associação. Das quatro placas existentes no edifício, duas na fachadauma das quais informa ser a casa onde viveu Tiradentes - e duas no hall de entrada, nenhuma possui os dizeres acima e nem foi colocada no período da comemoração do Centenário.

Chama atenção que, ao final do relato sobre a situação dos prédios ligados à Inconfidência Mineira, tenha sido citada a necessidade de recuperação de monumentos com base em seu valor artístico ${ }^{31}$, a exemplo da igreja de São Francisco de Assis, notória pelos trabalhos de Aleijadinho ali realizados. Embora silenciada nas escolhas feitas pelo $\| H G B$ inicialmente, a advertência reitera a valorização do estilo barroco, que desde 1911 vinha se fortalecendo a partir da
29. Nascido em Portugal em 1758 , foi jurista e historiador. Suspeito de envolvimento na Inconfidência Mineira, chegou a ser preso. Mas, como vereador, proferiu discurso em apoio à condenação dos inconfidentes e à execução de Tiradentes, como demonstração de fidelidade à Coroa Portuguesa, na Câmara de Vila Rica, em 22 de maio de 1792. Cf.: <https://pt.wiki pedia.org/wiki/Diogo_ Pereira_Ribeiro_de_Vas concelos $>$. O discurso pode ser lido em: Revista do Arquivo Público Mineiro; Ano I; Fasc. 3 - jul-set de 1896. p. 405- 411. Disponível em:<http://www.siaapm. cultura.mg.gov.br/modu les/ra pm/brtacervo. php?cid=19\&op=1>. Acesso em 18/02/2017.

30. Cf. A Placa (1921), grifo nosso.

31. "Todo monumento possui para nós, em virtude da concepção moderna, valor artístico apenas na medida em que corresponde às exigências da vontade artística moderna”, cf. Alois Riegl (2013, p. 48). Com base nessa premissa de Riegl, inferimos que, no caso em questão, a "vontade artística moderna" tinha por referência o barroco como a expressão artística pioneira, portanto, genuinamente nacional. 
32. É possível citar como exemplo o texto da Mário de Andrade, Aleijadinbo, de 1928. Conforme comenta Mario Roberto Bonomo (1998, p. 143-145), tratouse de um estudo desenvolvido no âmbito de reconhecimento, por parte dos modernistas, da arte barroca como autêntica arte brasileira, após primeira visita do poeta a Ouro Preto, em 1917.

33. A Arquidiocese de Mariana foi criada em 1906 , exercendo um importante papel na política mineira. Ver Mário Roberto Bonomo (1998, p. 160).

34. Segundo Bonomo (1998, p. 175-177), as próprias irmandades vendiam ou doavam objetos religiosos ao gosto dos colecionadores. Vale lembrar que, em 1928, numa demonstração de permanência dessa prática após a criação do Museu Arquiepiscopal, o Sr. Odorico Neves, da Irmandade de Nossa do Rosário dos Pretos ofereceu a Gustavo Barroso "Objetos que pertencem à igreja e interessam ao Museu [...] visto não pertencerem ao culto" Cf.: Museu Histórico Nacional (1944, p. 25).

35. D. Helvécio Gomes de Oliveira (1926).

36. Cf. Gustavo Barroso (1943, p. 580).

37. Augusto de Lima Júnior (1889-1970) era filho de (Antônio) Augusto de Lima, escritor, jurista e político. Lima Júnior atuou como jornalista e historiador. Foi membro do Instituto Histórico e Geográfico de Minas Gerais e da Academia Mineira de Letras. Ver Camila Kézia Ribeiro Ferreira (2011).

38. Cf. Gustavo Barroso (1943, p. 580). divulgação de estudos como os de Menezes e de Vasconcelos, aos quais outros se seguiriam. ${ }^{32}$ Também se relaciona com o interesse da Igreja Católica em se reaproximar do Estado e dos fiéis via proteção dos edifícios eclesiásticos, que deveriam ser vistos como pertencentes a toda a nação. Dom Helvécio Gomes de Oliveira, arcebispo de Mariana ${ }^{33}$ conseguiu o apoio de intelectuais e autoridades para a defesa dos bens da lgreja em Ouro Preto, tanto contra o comércio de antiguidades, ${ }^{34}$ quanto frente à deterioração dos imóveis pelo tempo e o abandono. Fechou as capelas mais afastadas do centro, recolheu seus objetos ornamentais e de culto, reunindo-os no Museu Arquidiocesano de Arte e História de Mariana, inaugurado em 1926. Na abertura festiva realizou-se o ato cívico de transferência da Bandeira do $17^{\circ}$ voluntário da pátria- pelo próprio alferes, que a teria levado na Retirada de Laguna - da Antiga Sé de Mariana para a recém-criada instituição. Estavam presentes políticos, militares, clérigos e homens de letras, entre os quais Gustavo Barroso, então diretor do Museu Histórico Nacional, convidado por d. Helvécio para ser um dos "protetores entusiásticos da projetada instituição". ${ }^{35}$

Para Gustavo Barroso, o momento seria o marco inicial de sua campanha pelo "salvamento" dos monumentos nacionais, especialmente os da cidade de Ouro Preto. Foi quando começou a tecer redes de relações com políticos, intelectuais, clérigos e militares mineiros, engrossando o coro contra o abandono em que se encontrava a antiga capital das Minas Gerais, o que pode ser percebido em relato que fez sobre sua visita de três dias à antiga Vila Rica após os festejos em Mariana. Seguiu em companhia do "saudoso capitão Pedro Gomes e mais alguns oficiais do Exército e da Marinha", ${ }^{36}$ tendo o poeta Augusto de Lima Júnior ${ }^{37}$ como cicerone. Já havia visitado Ouro Preto em 1910, "quando trabalhava em serviços ferroviários entre Congonhas e Fêcho do Funil, e ainda não tinha os olhos capazes de ver e admirar aquele relicário arquitetural" ${ }^{38}$

Sua presença em Mariana e Ouro Preto, naquele setembro de 1926, não apenas foi registrada com fotorreportagem na revista Fon-Fon do dia 18 de setembro do mesmo ano, ${ }^{39}$ mas também relatada em artigo de sua autoria, sob pseudônimo João do Norte, publicado no jornal Folha da Noite, com tífulo "Supra montem". ${ }^{40}$ No artigo, Barroso enaltece a arte barroca, atentando para o estado de degradação das construções. Numa atitude romântica, refere-se ao século XVIII ali representado por seus vestígios como se fosse possível vivenciá-lo novamente:

E por esses vales e ribeirões em fora, os olhos da nossa imaginação podem ver sem esforço, de tal modo o passado impregna aquela terra, as sombras dos bateadores, dos faiscadores e dos tropeiros. Quando a noite desce [...] os nossos ouvidos podem adormecer es- 
cutando o tropel dos terríveis Dragões de Minas e os gemidos lancinantes de Felipe dos Santos arrastado pelos cavalos por monte e vale. ${ }^{41}$

encanto por aquelas cidades mineiras pautava-se no fato de possibilitarem aos olhos verem "sem esforço" o passado, e aos ouvidos, escutá-lo. Em seu relato de viagem, Barroso expressa sua sensibilidade antiquária que o fazia partir "do vestígio à vertigem", 42 do fragmento à vivência imaginária em um tempo findo, como se fosse possível aos olhos e aos ouvidos trazê-lo à vida novamente. No caso de Mariana, "cidade arquiepiscopal", destacava-se também o recém-inaugurado Museu Arquidiocesano de Arte e História, merecendo seu idealizador palavras de enaltecimento:

D. Helvécio Gomes de Oliveira é como o diz Augusto de Lima Júnior, uma alma de Leão X desterrada nos sertões brasileiros. Ele ama o belo em todas as suas manifestações artísticas e seus olhos de idealista voltam-se sempre para o passado, à procura de tudo quanto a fé e o amor nele produziram de elevado. Nobre figura que se de longe interessa pela harmonia da sua vida, de perto atrai como um abismo de bondade cristã. Transformando a igreja inacabada de São Pedro [...] em um Museu de Arte e História, ele presta ao nosso país, onde tais coisas são tão descuradas, um serviço admirável e dá, ao mesmo tempo, aqueles cuja inação tem permitido se carregue do Brasil para o estrangeiro as maiores preciosidades das nossas igrejas e estabelecimentos antigos. ${ }^{43}$

No dia 22 de abril de 1927, Gustavo Barroso escreveu outro artigo referindo-se às cidades mineiras sob o título "Lendas de cidades mortas". 44 Mais uma vez assinando como João do Norte, propunha a produção de um livro sobre as "cidades mortas", ${ }^{45}$ sublinhando a importância de Aleijadinho e dos inconfidentes ao falar sobre Ouro Preto: "Em Minas, o passado adormeceu em cidades lendárias: Ouro Preto cheia de igrejas e da saudade do Aleijadinho e das lembranças dos Inconfidentes; Mariana, capital do Conde de Assumar". ${ }^{46}$ A campanha nesse caso voltava-se para o registro de acontecimentos e personagens dessas cidades em um livro de lendas, para o qual o autor apresenta uma espécie de roteiro. "Já era tempo de se recolherem as lendas maravilhosas que nasceram da tristeza dessas cidades mortas [...] Aí fica uma sugestão para ótimo livro". ${ }^{47}$

Nesse mesmo ano, como diretor do Museu Histórico Nacional, Barroso já era reconhecido como autoridade nos assuntos ligados à defesa dos monumentos. Tanto que atuou como secretário-geral da Comissão Internacional de Jurisconsultos no Rio de Janeiro e no ltamaraty, onde preparou documentação que foi apresentada na Conferência Pan-Americana de Havana. ${ }^{48}$

Embora em "O Culto da Saudade", publicado em 22 de dezembro de 1912 no Jornal do Commercio,49 Barroso já alertasse para a necessidade de
39. Ver Excursão à Mariana (1926).

40. Ver João do Norte (1926). Do latim, Supra montem significa na montanha. Este artigo, com algumas modificações, voltou à imprensa com o título "Cidades mortas do sertão”. Ver Gustavo Barroso (1928).

41. Cf. João do Norte (1926).

42. Cf. Francisco Régis Lopes Ramos (2014, p. 244254).

43. Cf. João do Norte (1926).

44. Ver João do Norte (1927).

45. "Expressão [também] usada por Alceu Amoroso Lima referindo-se a algumas das cidades mineiras que visitou em 1916, inclusive Ouro Preto", cf. Leila Bianchi Aguiar (2013, p. 182).

46. Cf. João do Norte (1927).

47. Cf. João do Norte (1927).

48. Ver Gustavo Barroso (1943, p. 582).

49. Ver João do Norte. (1912). 
50. "Oiro Preto, ninho de tradições e glórias, derroca-se, esboroa-se. Ninguém escora as ombreiras de pedra bruta, as paredes desaprumadas", cf. João do Norte (1912).

51. "Na remodelação da Bahia, nada se poupou. No Rio, todas as tradições se apagaram. O passado não merece consideração", cf. João do Norte (1912). Barroso assistia contrariado às reformas urbanas de modernização e embelezamento das antigas capitais, pelo fato de estarem pautadas na destruição de vestígios do passado, como se observou com as reformas do presidente Rodrigues Alves durante a gestão do prefeito Pereira Passos no Rio de Janeiro entre 1903 e 1906.

52. Ver Gustavo Barroso (1928).

53. Esses artigos foram publicados no volume 5 dos Anais do Museu Histórico Nacional dedicado a um dossiê sobre os feitos de Gustavo Barroso, no qual a Inspetoria de Monumentos Nacionais ocupa a maior parte das páginas. A intenção era que os artigos atestassem o pioneirismo de Gustavo Barroso nas campanhas pela proteção aos monumentos nacionais. Ver Museu Histórico Nacional (1944).

54. Ver João do Norte (1928a).

55. Ver João do Norte (1928b).

56. Ver João do Norte (1928c).

57. Cf. Gustavo Barroso (1943, p. 582). cuidado com os vestígios do passado das cidades brasileiras, citando Ouro Preto, 50 Olinda, Salvador e Rio de Janeiro, ${ }^{51}$ seu discurso em defesa dos monumentos passa a ser mais enfático nos artigos publicados em 1928. É o que se identifica em textos como "As cidades mortas do sertão"52 e a trilogia veiculada no Correio da Manhã 53: "As igrejas de Minas e a Sé Velha da Bahia", 54 "Ouro Preto, a cidade sagrada" 55 e "A casa de Marília". ${ }^{56}$ Especialmente nos três últimos artigos, não é apenas o discurso em prol dos monumentos que se nota mais forte, mas, sobretudo, o relato de suas ações como supervisor de obras de restauração de monumentos ouro-pretanos, trabalhando junto ao governo de Minas Gerais na gestão do presidente Antônio Carlos Ribeiro de Andrada.

Foi em 1928 que Gustavo Barroso procurou o presidente Antônio Carlos, conforme escreveu: "como amigo de longa data, através das mutações dos cenários políticos, desde quando fui Deputado Federal sob a sua liderança, de 1915 a $1918^{\prime \prime} .57$ Ofereceu seus serviços para fiscalizar a restauração de monumentos da cidade de Ouro Preto, considerando a urgente necessidade dessa tarefa. presidente de Minas Gerais aceitou seus préstimos, liberando uma verba de 200 mil cruzeiros para a realização das obras, feitas sob a responsabilidade técnica do engenheiro João Velloso, então responsável pelas finanças do município - o mesmo que viria a ser prefeito da cidade entre 1931 e 1936, quando Barroso retoma os trabalhos junto aos monumentos ouro-pretanos. ${ }^{58}$ Alguns reparos tinham sido realizados durante a gestão do presidente Melo Viana em Minas Gerais, entre 1924 e 1926, mas Barroso não os considerou satisfatórios. Ao abordar esse assunto, aponta as falhas das reformas, citando o caso da lgreja de São Francisco de Assis, e se coloca como pessoa capaz de conduzir os trabalhos de forma correta e competente:

Sr. Antônio Carlos pretende realizar na sua terra uma obra inteligente e digna de todos os louvores: a defesa do Patrimônio Histórico e Tradicional de Minas, que é dos mais ricos do Brasil. Já o Sr. Melo Viana dera alguns passos, os primeiros, nesse sentido, procurando impedir a saída de antiguidades do Estado e auxiliando a conservação e restauração de monumentos como a igreja de S. Francisco de Assis, em Ouro Preto. As obras executadas nesse maravilhoso templo alevantado por Aleijadinho, infelizmente, não foram confiadas a um conhecedor do assunto ou a um homem de gosto e saber. Assim, meteram no corpo da igreja um rodapé de ladrilhos brancos modernos. É sabido que as igrejas de Minas, com exceção do Carmo, de Ouro Preto, não têm azulejos... Que ao menos tivessem escolhido azulejos de estilo colonial ${ }^{59}$ - há tantos! -, e não esses de leiteria ou café suburbano.

As portas eram verdes, como de uso nas igrejas antigas. Pintaram-nas de castanho e fingindo madeira. A mesma coisa fizeram com todas as grades e balaustradas de jacarandá. Horrível! Por felicidade, em qualquer tempo, essa tinta poderá ser tirada com um pouco de soda cáustica, recebendo a madeira aquilo que merece: cera. ${ }^{60}$ 
Depois do acordo feito com os governos do estado de Minas e do município de Ouro Preto, Gustavo Barroso - sem receber nenhuma remuneração, como fazia questão de divulgar - fiscalizou obras de reparo em chafarizes e igrejas. Contou com a colaboração do prefeito Baeta Neves e de Odorico Neves, da Irmandade do Rosário, que financiou as obras na Igreja do Rosário e ofertou a Gustavo Barroso objetos ligados à cultura afro-brasileira, por não serem utilizados nos cultos católicos. ${ }^{61}$ Do ministro da Viação, Victor Konder, conseguiu o valor de 50 contos para reparos na Casa dos Contos, então sede dos Correios na cidade, e a liberação do engenheiro Epaminondas Vieira de Macedo para supervisão das obras. José Wasth Rodrigues, artista adepto do estilo neocolonial que ilustrou o livro de Gustavo Barroso Uniformes do Exército Brasileiro, em 1922, concebeu novos bancos de madeira para a lgreja do Rosário e desenhou um portão de ferro para o vestíbulo da mesma.

As intervenções de José Wasth Rodrigues na Igreja do Rosário parecem pautadas no princípio de restauração definido e praticado pelo arquiteto francês Eugène Emmanuel Viollet-le-Duc, segundo o qual a forma deve se adequar à função, a estrutura à forma e a ornamentação ao conjunto. ${ }^{62}$ Nessa perspectiva, é previsto por Viollet-le-Duc o restabelecimento de um edifício "em um estado completo que pode não ter existido nunca em um dado momento". 63 Certamente, o gradil de ferro não foi projetado na época da construção da lgreja do Rosário, no século XVIII; entretanto, sua colocação no século XX possibilitava uma vida mais longa a essa proteção do templo, uma vez que os portões de madeira que o antecederam estavam em mau estado de conservação. Substituí-los por exemplar similar significava nova intervenção em pouco tempo. Viollet-le-Duc indicava justamente isso: "Nas restaurações, há uma condição dominante que deve ter sempre em mente. É a de substituir toda parte retirada somente por materiais melhores e por meios mais eficazes ou mais perfeitos". Afinal era "necessário que o edifício restaurado tenha no futuro [...] uma fruição mais longa do que a já decorrida". ${ }^{64}$ Ainda segundo Viollet-le-Duc, "antes de tudo, é necessário que ele [encarregado da restauração] o faça viver". ${ }^{65}$ E devolver vida aos monumentos restabelecendo seus usos estava na pauta do dia de Gustavo Barroso e sua equipe. (Figuras 1,2,3 e 4).

Em relatório enviado por Barroso ao presidente Antônio Carlos, em $1^{\circ}$ de novembro de 1928, constam detalhes das obras realizadas nos chafarizes da Glória, dos Contos, do Largo de Dirceu, de Cláudio Manuel e do Alto da Cruz, além das igrejas do Rosário, de São Francisco de Assis, do Carmo, bem como da Capela de São João e da Matriz do Pilar. Na parte dedicada aos chafarizes, Barroso fala que todos os reparos foram muito bem feitos, reconstituindo partes que estavam danificadas e livrando os chafarizes da sujeira. No chafariz da Glória,
58. Ver Mário Roberto Bonomo (1998, p. 208).

59. O estilo colonial em questão é o barroco, sem dúvida. Entretanto, em 1937, Barroso escreveu sobre a inexistência desse estilo, como sendo nacional, em função de o barroco não ter se nacionalizado no Brasil. Segundo ele, "o barroco jesuítico veio para o Brasil e aqui produziu obras de arte admiráveis como as igrejas da Bahia e de Minas. Aqui porém viveu e cresceu barroco jesuítico português, sem lograr nacionalizar-se, ambientando-se como se deu em alguns países do mesmo continente." Ambientar-se significava adotar motivos da fauna e da flora tropicais em sua produção, o que não foi verificado. Cf. Gustavo Barroso (1937). Como escrevera em 1921, em artigo intitulado "Arquitetura Nacional", respondia à polêmica criada entre José Marianno Filho e Cristiano das Neves sobre a consideração do barroco como arquitetura nacional. O primeiro, defendia esse caráter do barroco ao valorizar suas raízes portuguesas. Não por acaso, inspirou-se nessa arte para a formulação do que definiu como arquitetura neocolonial, que seria a arquitetura colonial adaptada à modernidade. Já o segundo considerava o estilo barroco decadente para corresponder ao seu ideal de nacionalidade. Ver João do Norte (1921).

60. Cf. João do Norte (1928a), grifo nosso.

61. Os objetos ofertados por Odorico Neves da Irmandade de Nossa Senhora do Rosário foram um instrumento de percussão denominado caxambu e uma boneca conhecida por Maria Cambinda. Ver Museu Histórico Nacional (1944, p. 25 e 26). 
que "estava estragadíssimo pelo tempo, pelo abandono e sobretudo pelas raízes do bambual que crescera por trás", foram feitos reparos e retirado todo o bambual que ameaçava sua estrutura. ${ }^{66}$

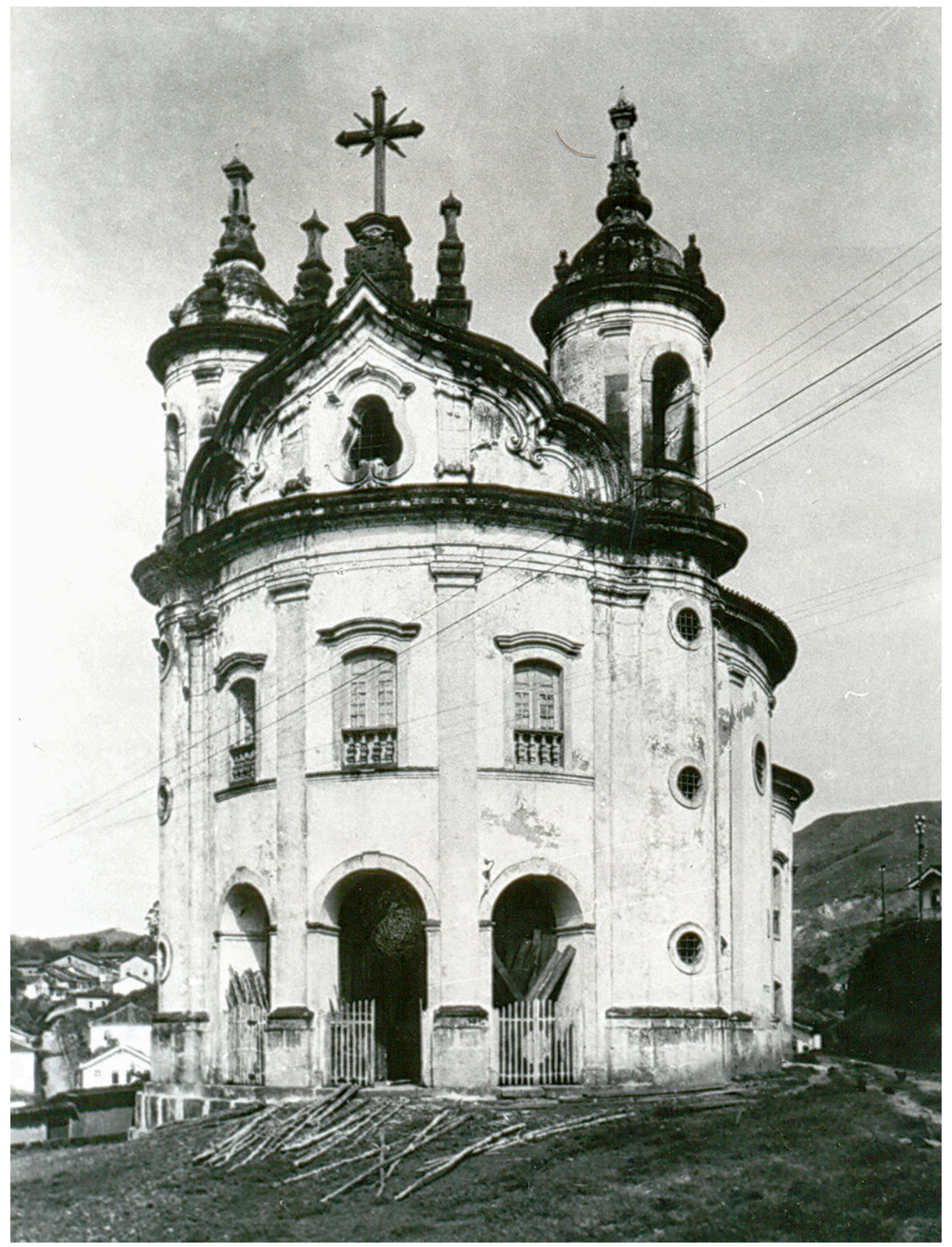

Figura 1 - Igreja do Rosário antes da restauração de 1928, s/d. Fotografia de Luiz Fontana. Acervo do Arquivo Central do IPHAN, Seção Rio de Janeiro. 
62. Ver Beatriz Mugayar Kühl (2000, p. 13).

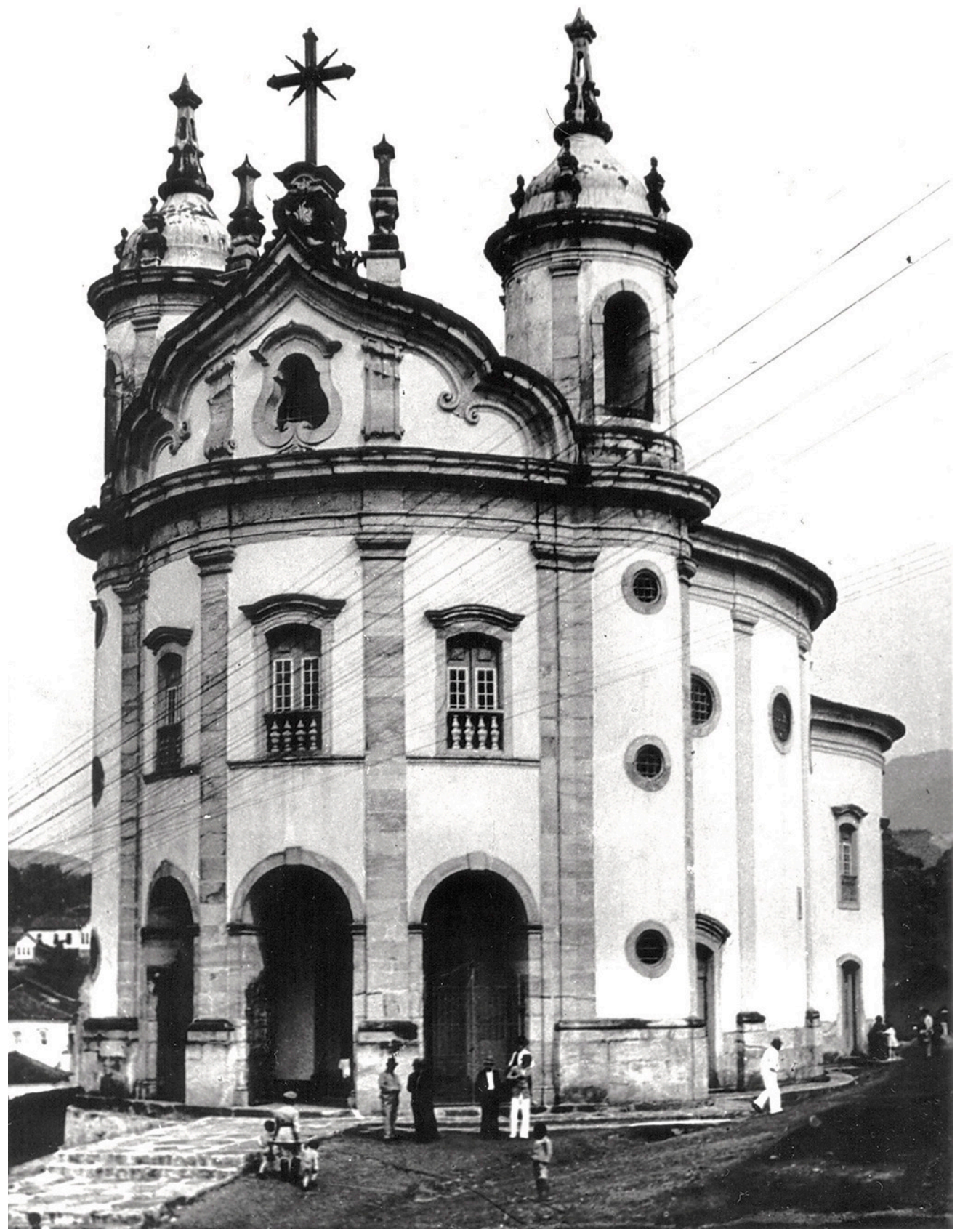

Figura 2 - Igreja do Rosário no processo de restauração, já com a fachada reparada, s/d. Fotografia de Luiz Fontana. Acervo do Arquivo Central do IPHAN, Seção Rio de Janeiro.
63. Cf. Eugène Emmanuel Viollet-le-Duc (2000, p. 29).

64. Cf. Eugène Emmanuel Viollet-le-Duc (2000, p. 54).

65. Cf. Eugène Emmanuel Viollet-le-Duc (2000, p. 56).

66. Cf. Museu Histórico Nacional (1944, p. 28-30). 


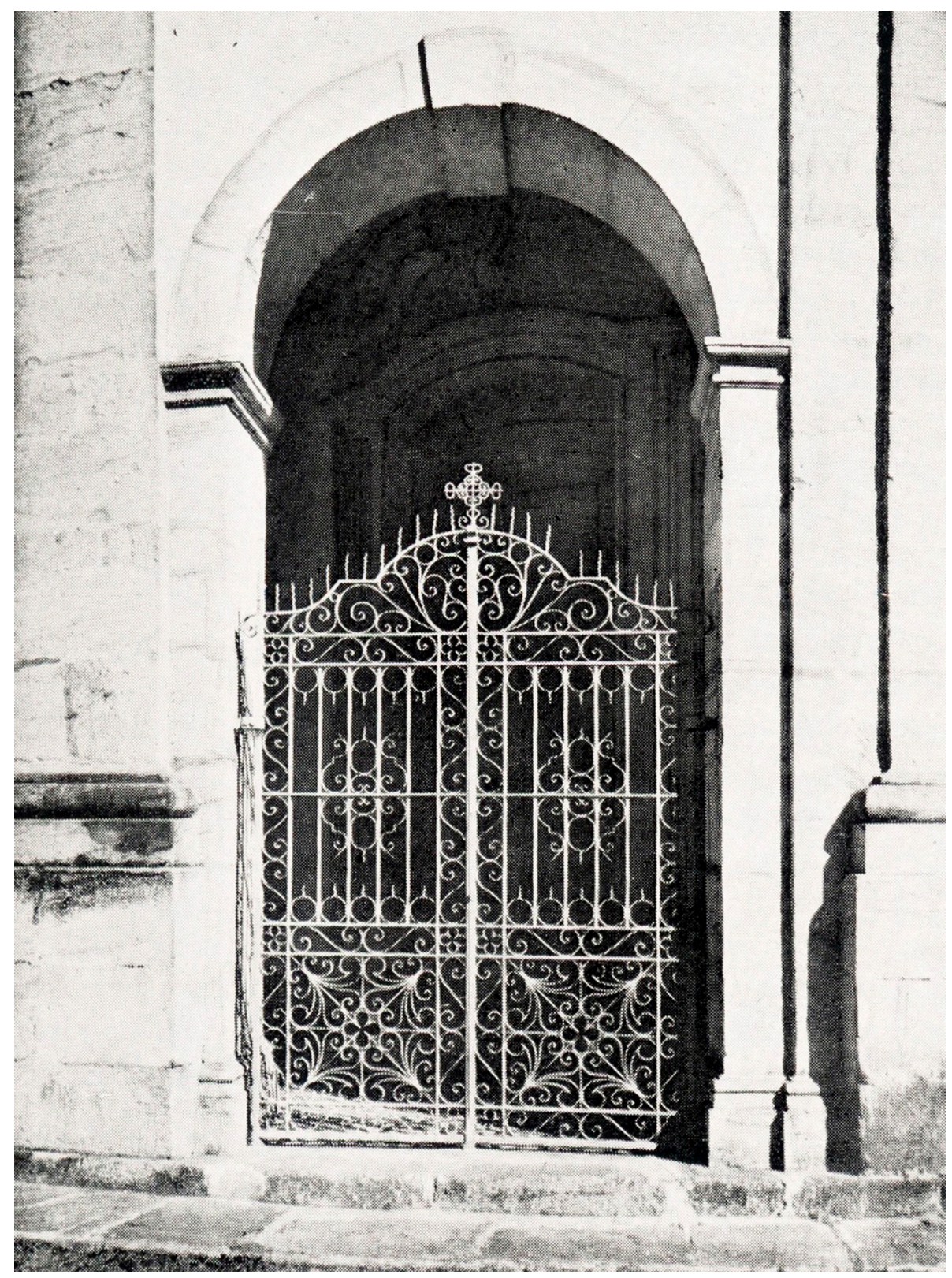

Figura 3 - Detalhe da Fachada da Igreja do Rosário com destaque para o gradil de ferro inserido nas obras entre 1928 e 1930, s/d. Fotografia de Luiz Fontana. Fonte: Anais do Museu Histórico Nacional, v. 5, 1944/1955.

Figura 4 (abaixo) - Detalhe da fachada da lgreja do Rosário com destaque para o gradil que ali permanece. Fotografia de José Neves Bittencourt, 2003 


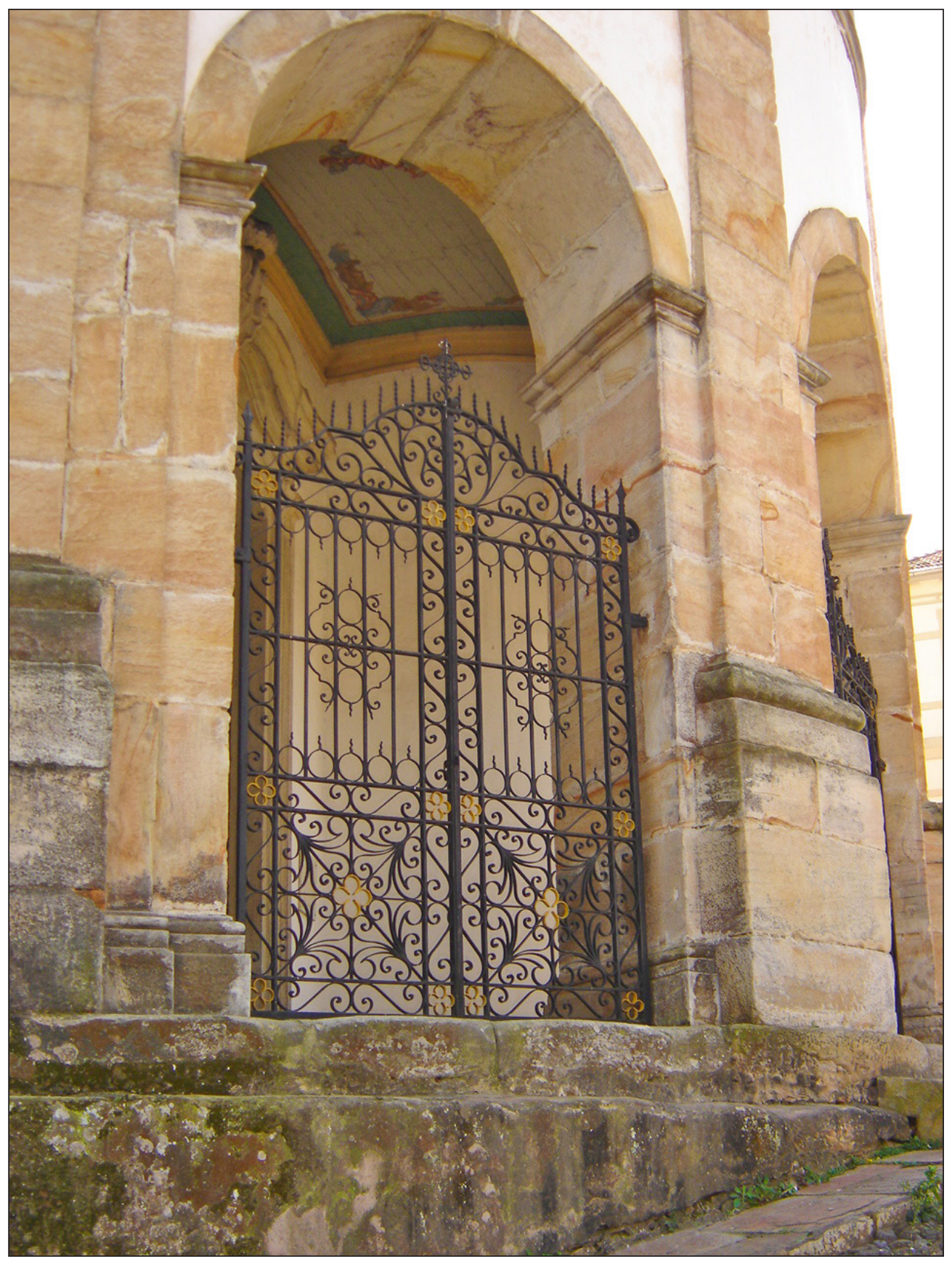

No relatório, todas as obras apresentadas se encontravam em andamento. Embora não conste documentação que informe sobre a conclusão dos trabalhos, sabe-se que a Casa dos Contos passou por intervenções que consistiram no 
67. Cf. Museu Histórico Nacional (1944, p. 24).

68. Cf. Comité International des Sciences Historiques (1930).

69. Vicente de Andrade Racioppi, advogado e escritor, foi uma das personalidades locais envolvidas com a preservação de Ouro Preto e com a divulgação de sua história. Entre suas principais realizações está a fundação do Instituto Histórico de Ouro Preto em 1931.

70. Ver Vicente Andrade Racioppi (1930).

71. Ver A fundação do Instituto Histórico de Ouro Preto (1931).

72. Cf. Cláudia Damasceno Fonseca (2011 p. 522).

73. Mário de Andrade, Oswald de Andrade, seu filho Nonê, Tarsila do Amaral, dona Olívia Guedes Penteado, René Thiollier e Godofredo Silva Teles. A caravana modernista, como ficou conhecida a expedição, percorreu várias cidades históricas mineiras, "redescobrindo" o passado colonial, para que o francês Blaise Cendrars conhecesse o Brasil. Ver Carla Maria Junho Anastasia, Letícia Julião e Carmem Silvia Lemos (1999, p. 128). Vale lembrar também o artigo de José Marianno Filho de 1929,"O patrimônio artístico da nação. Apud. Carlos Kessel (2008, p. 219).

74. Sobre a valoração de Ouro Preto pelos diferentes grupos de intelectuais, ver Leila Bianchi Aguiar (2013). A autora analisa como a cidade era vista negativamente no século XIX, especialmente pelos viajantes que a caracterizavam como feia e atrasada e como essa percepção foi dando lugar a outras, positivas, a partir de princípios do século XX. fortalecimento de sua estrutura interna "com um vigamento de concreto, arcabouço que, sendo invisível, em nada prejudicou o aspecto e conservou de modo definitivo a sua estrutura". ${ }^{67}$ Dali, Barroso adquiriu para o acervo do Museu Histórico Nacional um arquibanco e uma arca de guardar valores. As obras foram encerradas em 1930, com a saída do presidente Antônio Carlos do governo, em decorrência da Revolução de 1930. Barroso viria a dar continuidade às atividades inacabadas em 1935, à frente da Inspetoria de Monumentos Nacionais. Enquanto isso, mantinha contatos na cidade, sobressaindo-se cada vez mais como autoridade no campo da proteção dos monumentos, que vinha se consolidando no cenário internacional, onde também ganhava projeção.

Em 1930, foi nomeado para integrar a subcomissão brasileira de Iconografia filiada ao Comité International des Sciences Historiques, com sede em Washington. ${ }^{68}$ No mesmo ano, convidado por Vicente de Andrade Racioppi, 69 integrou, como membro de honra, a comissão das comemorações do bicentenário de Aleijadinho, presidida por d. Helvécio de Oliveira. ${ }^{70}$ No ano seguinte, estava entre os fundadores do Instituto Histórico de Ouro Preto, outra iniciativa de Racioppi, que ocupou o cargo de primeiro-secretário, agregando políticos, clérigos, militares e intelectuais sob as bênçãos do patrono Aleijadinho. ${ }^{71}$

Iniciativas de valorização de Ouro Preto, como as de d. Helvécio com a criação do Museu Arquiepiscopal em Mariana, do presidente Antônio Carlos ao promover reformas em monumentos da cidade e de Racioppi liderando a fundação do Instituto Histórico da cidade, aconteciam em paralelo com outras, realizadas por diferentes grupos. Ouro Preto tornava-se a principal referência para a construção da identidade nacional. Os mais conservadores, como Barroso e seus colegas do movimento neocolonial, primavam pela tradição, compreendendo a cidade como testemunho da civilização europeia nos trópicos, valorizando seus templos, "as ruas calçadas, as pontes de pedra e os chafarizes públicos como signos de prosperidade e prestígio urbano"72 dos tempos coloniais. Já alguns historiadores, como os sócios do IHGB citados anteriormente, tinham na antiga capital de Minas Gerais o berço das ideias da independência e da república, por ter ali acontecido a Inconfidência Mineira. Por sua vez, os modernistas que excursionaram pela cidade em $1924^{73}$ se apropriaram da antiga Vila Rica ao eleger sua arte e sua arquitetura como autênticas expressões da brasilidade, estabelecendo elos entre suas produções modernas e a estética da cidade colonial, sendo as primeiras tributárias da última. ${ }^{74}$

Enfim, diferentes olhares convergiam para a antiga Vila Rica, tornada a "nossa Roma", 75 nos projetos de identificação e valoração do "autêntico" nacional 
então elaborados, o que pode explicar ter sido Ouro Preto a primeira cidade reconhecida como Monumento Nacional, em 1933. Segundo Ferreira, Augusto de Lima Júnior foi o responsável pelo projeto que levou o presidente Getúlio Vargas a conceder o título no Decreto-Lei 22928 de 17 de julho de 1933.76 Gustavo Barroso comentou sobre o papel do jornalista e escritor mineiro nesse processo, procurando também sublinhar sua participação:

No regresso ao Rio, no vagão especial em que viajamos, Pedro Gomes, Augusto de Lima e eu assentimos ser necessário e urgente trabalhar pela defesa daquele patrimônio que se esfacelava. A mim, como único elemento oficial então encarregado da guarda das relíquias da Pátria, caberia a ação junto aos poderes públicos. Pedro Gomes conseguiria o apoio do Ministro da Guerra, de cujo gabinete fazia parte. Augusto de Lima poria a sua pena a serviço da tradição e da história. O que foi o trabalho de Augusto de Lima di-lo a triunfal visita do Ministro da Marinha a Vila Rica e Mariana anos depois, levando o Decreto que tornava a velha cidade Monumento Nacional e que o escritor conseguiria obter do espírito de compreensão do Presidente Getúlio Vargas. ${ }^{77}$
75. Cf. José Neves Bittencourt (2007, p. 123-137)

76. Ver Camila Kézia Ribeiro Ferreira (2014, p. 10 e 13). Nesse trabalho, a autora destaca também a importância de Augusto de Lima Júnior, em 1936, no processo de repatriamento dos restos mortais dos inconfidentes que foram degredados para a África.

77. Cf. Gustavo Barroso (1943, p. 380).

78. Ver Suely Moraes Ceravolo $(2011 ; 2012$, p. $122-$ 144).

79. Ver Rodrigo Cantarelli (2014).

80. Cf. Ouro Preto (1931).

81. Cf. Ouro Preto (1931).

\section{A CORRIDA POR UMA LEGISLAÇÃO}

As décadas de 1920 e 1930 do século XX foram marcadas por uma série de projetos voltados para a proteção de monumentos nacionais. Intelectuais e políticos, após assistirem à experiência destruidora da Primeira Guerra Mundial e dos processos de remodelação das cidades - a exemplo do que pôs abaixo o Morro do Castelo no Rio de Janeiro, em 1922 -, se batiam pela integridade de antigas edificações, que estavam em risco de desaparecer diante da iminência de novo conflito ou frente às reformas urbanas de modernização e embelezamento. A movimentação do mercado de antiguidades também preocupava, pois, sem regulamentação, fragmentava coleções e dilapidava o patrimônio nacional com a exportação de objetos representativos da história e da arte nacionais. No sentido de conter esse movimento, os Estados da federação que possuíam acervo do período colonial saíram na frente dos demais, instituindo Inspetorias Estaduais de Monumentos Históricos. Foi o caso da Bahia, em 1927,78 e de Pernambuco, em 1928.79

Em nível municipal, foi Ouro Preto que deu o primeiro passo. Em 1931, o prefeito João Velloso assinou o Decreto n 13 com o objetivo de "conservar o aspecto colonial [da cidade] transmitido de nossos antepassados". ${ }^{80} \bigcirc$ decreto não permitia a "construção de prédios e edifícios em desacordo com o estilo colonial da cidade"81 no perímetro urbano. Os prédios existentes construídos em outro estilo deveriam ter suas fachadas modificadas para se adequarem às "feições coloniais", quando necessitassem de reparos. $\bigcirc$ Decreto $n^{\circ} 25$, assinado por 
82. Cf. Ouro Preto (1932).

83. Ver Leila Bianchi Aguiar (2016, p. 87-106).

84. Cf. Ouro Preto (1931).

85. Cf. Rodrigo Melo Franco de Andrade (1952, p. 23).

86. Cf. Museu Histórico Nacional (1931, p. 14).
Velloso no ano seguinte, complementou as determinações do anterior, impedindo a mudança do estilo antigo das construções nos casos de "reparos, consertos, reconstruções e limpezas [...] quer nas fachadas ou cimalhas, em quaisquer detallhes". ${ }^{82}$ Sobre essa legislação, Leila Aguiar sublinha a preocupação do prefeito em preservar o "interesse" dos turistas pela cidade. ${ }^{83}$ Conforme consta no Decreto $n^{\circ} 31$, "ferem dolorosamente a sensibilidade dos turistas os prédios que destoam o tipo colonial." "84 Então, valeria a pena não apenas conservar o que existia em "feições coloniais", mas também modificar o que assim não se apresentava, com - claro objetivo de manter uma unidade estética da arquitetura urbana que agradasse o olhar dos visitantes.

Na esfera federal, quatro projetos de lei foram enviados ao Congresso, com vistas a normatizar o controle e a proteção do patrimônio sob administração do Estado, mas não chegaram a ser votados: o de autoria de Alberto Childe, voltado para a defesa do patrimônio arqueológico, em 1920; outro elaborado pelo deputado federal pernambucano Luís Cedro, em 1923;0 do deputado federal por Minas Gerais Augusto de Lima, em 1924 - este específico para proibir a "saída de obras de arte retrospectiva do país" 85 - e, finalmente, o que foi escrito pelo deputado federal baiano José Wanderley de Araújo Pinho, em 1930.

O Museu Histórico Nacional começava uma campanha para que a proteção de monumentos fosse integrada às atividades institucionais. É o que se lê no Relatório de Atividades de 1931, encaminhado ao Ministério da Educação e Saúde (MES) por Rodolfo Garcia, que assumiu a direção do MHN durante o período de 10 de dezembro de 1930 a 14 de novembro de 1932:

Sentimos hoje necessidade de um serviço federal, que fiscalize, promova os meios de conservação, resguarde e inventarie os monumentos tradicionais que, espalhados pelo país, atestam a nossa educação nacional e a progressiva civilização do Brasil.[...] Essa Inspetoria, caso V. Ex. conviesse na sua criação sem ônus para os cofres da nação, poderia ser exercida pelo Diretor do Museu Histórico, sem gratificação especial, e logo regulamentada, de modo a armar-se com as atribuições necessárias para um entendimento direto com as administrações dos Estados, as instituições particulares, ou centros de turismo etc. A importância desta matéria, o seu alcance nacional, os cuidados que the dão nos países mais cultos, os governos que tem complexos órgãos de proteção das relíquias arquitetônicas do passado, dispensam outros argumentos em favor da ideia, que submeto ao elevado julgamento de V.Ex. ${ }^{86}$

A solicitação é identificada com o interesse em aproximar o Brasil "dos países mais cultos", não mais procurando seguir os padrões de modernização urbana ditados pela Europa, baseados na destruição daquilo que não representasse o progresso. Dessa vez, os valores de civilidade e cultura estão afinados com uma 
postura oposta: a de salvar bens históricos e artísticos que pudessem contribuir com a construção de elos com o passado. Dois anos depois, a proposta de criação de um órgão com esta finalidade no $\mathrm{MHN}$ volta a ocupar as páginas do Relatório Institucional. Quem o assinou foi Gustavo Barroso, que retornava à direção ocupada por Rodolfo Garcia durante os dois anos de seu afastamento:

Devo insistir na necessidade que reconheço presente, de regular o Governo a defesa do Patrimônio Histórico e artístico do País. Enquanto não tivermos uma organização administrativa acauteladora daquele patrimônio, e em harmonia com uma legislação adequada, meios de prevenção contra os assaltos que constantemente sofrem os monumentos históricos do Brasil, mal protegidos pelos poderes locais dos Estados e municípios, continuaremos a assistir a devastação da nossa riqueza tradicional... No Brasil, não me parece aconselhável a criação de um organismo especial para tal função: o Museu Histórico Nacional, sem ônus para os cofres federais poderia realizar aquela tarefa com a atribuição que por decreto se the conferisse de Inspetoria de Monumentos Nacionais. ${ }^{.7}$

Uma vez Ouro Preto elevada a monumento nacional, faltava um regulamento para efetivar a sua defesa e a de outras cidades que assim viriam a ser consideradas. Essa falta era sentida e denunciada por Gustavo Barroso em paralelo à sua atuação no cenário internacional. Destacamos a Comissão Internacional dos Monumentos Históricos, criada em 1933, junto ao Escritório Internacional de Museus, um departamento do Instituto Internacional de Cooperação Intelectual (IICI) sediado em Paris, no qual Gustavo Barroso passou a atuar a partir de junho de 1934, indicado, como representante do Brasil, pelo Ministro da Educação e Saúde, Washington Pires. ${ }^{88}$ Mesmo antes de sua nomeação, Barroso emitia pareceres sobre os projetos de cooperação internacional para a proteção do patrimônio histórico e artístico das nações participantes do $\mathrm{ICl}$. Assim procedeu em 24 de janeiro de 1934, quando o tema em discussão era o repatriamento de objetos de interesse histórico, artístico ou científico que tivessem saído do país de forma ilícita. Foi favorável que o Brasil apoiasse o projeto, pois este seria interessante para o País, visto a necessidade de uma legislação específica para proteger o patrimônio nacional. ${ }^{89}$

Antes da participação do Brasil na assinatura do Pacto de Röerich 90 - o que aconteceu com a representação de Oswaldo Aranha, embaixador do Brasil nos Estados Unidos, em 1935-Barroso comentava sobre a importância de ter o País entre os signatários do documento, emitindo parecer sobre o assunto, certamente solicitado pelo MES. Reforçava seu argumento alegando a urgência de uma legislação interna que regulamentasse os serviços de proteção dos monumentos:

Sendo o referido Pacto [Röerich] obra da diplomacia americana, sendo obra de verdadeiro espírito de amor às coisas da Humanidade, o Brasil pela sua tradição de cordialidade, de
87. Cf. Museu Histórico Nacional (1933, p. 2), grifo nosso.

88. Ver Ministério da Educação e Saúde Pública (1934).

89. Ver Gustavo Barroso (1933).

90. Apresentado por Nicholas Röerich, no ano de 1929 , em Nova York, o pacto sugeria que uma bandeira da paz tremulasse nas edificações protegidas em período de guerra, tendo sido este artista indicado por essa medida para o Prêmio Nobel da Paz. Foi apresentado na Sétima Conferência Internacional dos Estados Americanos que teve lugar em Montevidéu, em 1933, e assinado pelos 20 países participantes, no dia 15 de abril de 1935, em Washington. O Pacto tinha por objetivo: "(...) a adoção universal de uma bandeira a fim de preservar em qualquer tempo de perigo todos os monumentos imovíveis nacionais ou pertencentes a particulares, que formam o tesouro cultural das nações... levando a efeito o fato de que os tesouros da cultura sejam respeitados em época de guerra e de paz". Cf.: $<$ ht tp://roerich.org.br/portal/ pacto-roerich/>. Acesso em 23/01/2004 
91. Cf. Museu Histórico Nacional (1934a), grifo nosso.

92. Referia-se às Inspetorias de Monumentos Estaduais da Bahia, criada em 1927, e de Pernambuco, em funcionamento desde 1928.

93. Cf. Secretaria de Estado da Educação e Saúde Pública. Ofício (1934).

94. Cf. Museu Histórico Nacional (1934b).

95. Ver Ministério da Educação e Saúde (1946, p. 27).

96. Cf. Ministério da Educação e Saúde (1946, p. 28). pacifismo, de dedicação às boas causas, não pode ficar alheio ao mesmo, devendo apressar-se em dar-the a sua assinatura. [...] A proteção do tesouro cultural brasileiro, segundo o texto do Pacto, implica a necessidade duma legislação interna que assegure o respeito a esse tesouro; como também a organização do catálogo das relíquias e monumentos, dependentes daquela lei. Esta Diretoria, por solicitação vossa, já se manifestou favoravelmente quanto à lei em questão. Agora, coerentemente, se manifesta a favor da coparticipação do Brasil no Pacto Roerich. ${ }^{91}$

Ao se referir a uma solicitação do Ministério à qual teria se manifestado favoravelmente, Barroso tratava de uma minuta de regulamento da Inspetoria enviada para seu parecer, acompanhada de algumas razões elencadas pelo ministro a serem consideradas na avaliação. Entre as considerações estavam: a urgência em defender o patrimônio brasileiro e fiscalizar o comércio de antiguidades, a participação do Brasil no $\| \mathrm{Cl}$, as solicitações enviadas por Barroso e Garcia nos relatórios de atividades do Museu Histórico Nacional, o fato de "vários" estados da federação já possuírem legislação própria ${ }^{92}$ e dos países "mais adiantados" iá contarem com leis específicas, a exemplo da França e ltália. ${ }^{93}$ Embora tenha aplaudido o projeto, Barroso esperava "sugerir outras ideias, ditadas pela experiência, pela legislação comparada e pelas opiniões dos interessados na parte que se refere aos proprietários de objetos históricos e artísticos". ${ }^{94}$ Assim procedendo, pedia um espaço para interferir no projeto, com base nos seus conhecimentos, no cotejamento com outras leis existentes e na troca com os colecionadores de arte e antiguidades. Ao que tudo indica, suas sugestões foram acatadas.

A minuta acabou servindo de base para a redação final do novo regulamento do $M H N$, aprovado pelo Decreto $n^{\circ} 24.735$ de 14 de julho de 1934, especialmente no que diz respeito ao seu capítulo VIII, dedicado à Inspetoria de Monumentos Nacionais (IMN), criada pelo mesmo documento como um departamento do MHN - a exemplo do Curso de Museus, já em funcionamento desde 1932. ${ }^{95}$ Já no seu Artigo $1^{\circ}$, o Regimento apresenta as novas atribuições da instituição, entre as quais "exercer a inspeção dos Monumentos Nacionais e do comércio de objetos históricos e artísticos". 96 No parágrafo único do Artigo $1^{\circ}$, percebemos três artigos da minuta aglutinados. Separadamente eles determinavam o seguinte:

Artigo 1: ' $\bigcirc$ Governo Federal declarará monumentos nacionais para efeito de sua defesa e conservação, os imóveis de grande significação histórica ou valor artístico que por isso mereçam ser incluídos no patrimônio tradicional do Brasil'. [...] Artigo 3: A Inspetoria de Monumentos procederá à elaboração do catálogo geral dos edifícios de assinalado interesse artístico-histórico existentes em todo o país. [...] Artigo 11: A Inspetoria de Monumentos entrará em entendimento com os governos dos Estados no sentido de ser uniformizada a 
legislação referente à proteção e conservação dos monumentos nacionais, e à guarda e fiscalização dos objetos histórico-artísticos, e de maneira a caber aos Estados os encargos desse serviço nos respectivos territórios. ${ }^{97}$

Quando reformulados na redação final do Regimento, formando o Parágrafo único do Artigo $1^{\circ}$, ficava determinado que:

para fins de inspeção, [o MHN] organizará um całálogo dos edifícios de assinalado valor e interesse artístico-histórico existente no país, propondo ao Governo Federal, os que se devem declarar em decreto Monumentos Nacionais; entrará em entendimento com os governos dos Estados, no sentido de se uniformizar a legislação sobre a proteção e conservação dos Monumentos Nacionais, guarda e fiscalização dos objetos histórico-artísticos, de maneira a caber aos Estados os encargos desse serviço nos respectivos territórios. ${ }^{98}$

Embora a iniciativa de definir o que fosse Monumento Nacional continuasse nas mãos do Governo Federal, ao organizar um catálogo com os edifícios de considerado valor, a Inspetoria participaria da classificação do que deveria ser valorizado como tal, ampliando assim seu raio de ação. Entretanto, nessa ação compartilhada com o Governo federal, não estão expostos os critérios para catalogação dos imóveis.

Quanto à legislação sobre a proteção e conservação dos monumentos nacionais a cargo dos estados, o Museu lideraria uma uniformização. Parecia haver uma expectativa de manter órgãos de defesa em nível estadual, como o da Bahia, que só encerrou suas atividades em 1938, orquestrados pela instituição sediada no MHN.

A IMN consta como o oitavo capítulo do documento. Dos 17 artigos da minuta, excetuando os três que foram aproveitados inicialmente, quatro foram suprimidos e os outros 10 foram mantidos, mas modificados, e um artigo foi incluído. A versão final do regimento do novo departamento acabou sendo definida no sentido de garantir maior centralidade e autoridade do MHN frente às ações de controle e fiscalização, especialmente no que tange à avaliação e à autenticação de objetos e ao comércio de antiguidades. Segundo Barroso, "[...] o Ministro da Educação Dr. Washington Pires, influenciado pela exposição que the fiz apoiado por seu Chefe de Gabinete, Heitor de Faria, decidiu comigo, numa noite a criação da Inspetoria de Monumentos Nacionais [...]". 99

Na parte do regimento aprovado, relativa à $I M N$, quase não aparecem mais referências aos monumentos edificados. $\bigcirc$ primeiro artigo, de número 72 , estabelece que "os imóveis classificados como monumentos nacionais não poderão ser demolidos, reformados ou transformados sem a permissão ou fiscalização do Museu Histórico Nacional". ${ }^{100} \bigcirc$ parágrafo único que o segue estabelece que
97. Cf. Secretaria de Estado da Educação e Saúde Pública (1934).

98. Cf. Ministério da Educação e Saúde (1946, p. 28).

99. Cf. Gustavo Barroso (1943, p. 584-5).

100. Cf. Ministério da Educação e Saúde (1946, p. 41), grifo nosso. 
101. Cf. Ministério da Educação e Saúde (1946, p. 41).

102. Cf. Ministério da Educação e Saúde (1946, p. 42).

103. No que diz respeito aos limites da Inspetoria, Rodrigo Melo Franco de Andrade foi ainda mais crítico, afirmando que "a eficácia das disposições [...] estava condicionada à validade que elas poderiam ter, com seu caráter de normas apenas regulamentares, para estabelecer restrições aos direitos individuais, mesmo no regime discricionário então vigente no Brasil [...] à organização geral da defesa do patrimônio de arte e de história no país restava ainda por fazer por meios legais mais válidos e eficazes que os contidos nas disposições regulamentares daquele estabelecimento.”, cf. Rodrigo Melo Franco de Andrade (1952, p. 48 e 51).

104. Cf. Ministério da Educação e Saúde (1946, p. 42), grifos nossos.

105. Cf. Ministério da Educação e Saúde (1946, p. 42), grifos nossos.

106. Ver Ministério da Educação e Cultura (1980, p. 49). Para um estudo comparativo mais detalhado entre o regulamento da IMN do MHN e os projetos elaborados anteriormente, ver Márcia Chuva (2009, p. 152-159). A autora sublinha que o projeto de Pinho - que certamente esteve na base do projeto enviado pelo MES para parecer de Barroso e, consequentemente, fundamentou o regimento da IMN - bem como o de Luiz Cedro (1923) e o de Augusto de Lima Júnior (1924) foram inspirados na legislação francesa de 1913, que também é citada nas justificativas do Ministro nas considerações que acompanham o pedido de parecer a Barroso.Ver, também, Aline Montenegro Magalhães (2004, p. 67-79). "independem de licença e fiscalização os trabalhos de conservação e consertos urgentes que não impliquem modificação essencial do prédio". ${ }^{101} \bigcirc$ documento só aborda os imóveis novamente no artigo 78, quando afirma que: "para efeito da inspeção de monumentos históricos, o diretor do Museu Histórico Nacional designará representantes seus onde for conveniente, considerando-se o serviço relevante o que os mesmos prestarem". ${ }^{102}$ Não cabia à IMN nenhuma responsabilidade além de autorizar e fiscalizar reformas nas edificações declaradas monumentos. Ou seja, não estava entre suas atribuições a realização de obras de restauração dos bens.

Outra alteração significativa nos artigos que permaneceram foi a substituição do "Governo Federal" e da "Inspetoria de Monumentos" pelo "Museu Histórico Nacional" e pelo "diretor geral do Museu Histórico Nacional" e "seus representantes" como as únicas autoridades das deliberações do novo órgão, que antes não apareciam em nenhum momento. Essa mudança diz muito sobre os limites da IMN como um departamento do $M H N$, por restringir sua autonomia para a realização das atividades previstas. ${ }^{103}$ Também parecia estar em sintonia com os interesses de Barroso em capitalizar para o MHN uma projeção em âmbito nacional, no que diz respeito não apenas ao comércio de antiguidades, mas à obtenção de maior prestígio e poder sobre as coleções públicas e particulares; uma vez que, conforme estabelecia o artigo 80, "as pessoas e corporações que possuírem objetos e relíquias artísticas ou históricas são obrigadas a fornecer a relação dos mesmos ao Museu Histórico Nacional e não poderão negociá-los sem prévia consulta a este, que terá preferência". ${ }^{104}$ Dessa maneira, a legislação abria uma brecha para o MHN aumentar o seu acervo, o que poderia acontecer também segundo o que estava previsto no Artigo 76: "Os objetos apreendidos por infração destes dispositivos passarão a fazer parte do patrimônio nacional, no Museu Histórico Nacional. ${ }^{105}$ Esses artigos, certamente foram inspirados nos que abordam o mesmo tema no projeto de Wanderley Pinho. Porém, no documento elaborado pelo deputado baiano, estava prevista uma ação conjunta com as repartições congêneres dos estados da federação que, aqui, foram ignoradas. ${ }^{106}$

O MHN, por intermédio de seu diretor e representantes, passaria a ter o monopólio da valoração e da autenticação dos objetos a serem catalogados e comercializados. Afinal, somente ao Museu caberia a autoridade para autenticar os objetos artísticos históricos que the fossem apresentados, mediante requerimento das partes interessadas e de acordo com a tabela de peritagem anexa ao regulamento. Conforme o artigo 82: "Os negociantes de antiguidades e obras de arte de qualquer natureza ficam obrigados a um registro especial no Museu Histórico Nacional ou nas repartições estaduais que o representem, não podendo vender objetos que não devidamente autenticados". Este é o 
segundo artigo em que há uma divisão de atribuição com as "repartições estaduais". Já o artigo 74 voltava a centralizar as ações quando trata da exportação de objetos, ao determinar que esta operação "só será permitida mediante autorização do diretor geral do Museu Histórico Nacional, ou de seus representantes, depois de paga, na repartição, taxa especial de $300 \$ 00$ sobre - valor dado pela avaliação feita no Museu". ${ }^{107}$

Quanto à elaboração de catálogo, consta no artigo 73 da versão final a atribuição do Museu Histórico Nacional de organizar um "tanto quanto possível completo, dos objetos histórico-artísticos de notável valor existentes no país, no qual os particulares poderão requerer a inclusão dos de sua propriedade, o que será deferido após exame, identificação e notificação". ${ }^{108}$ Enquanto a IMN não tinha autonomia para declarar "edificações" como monumentos nacionais, restringindo-se à função de propositura ao Governo Federal, quando se tratava de objetos a determinação era outra. Não apenas impunha que fossem fornecidas informações sobre objetos históricos e artísticos, como deixava entendido que os colecionadores teriam suas obras mais valorizadas a partir do momento em que essas constassem no catálogo do MHN. Afinal, estariam registradas em um instrumento específico de reconhecimento, após passar pelo crivo de uma autoridade especializada.

A partir de uma política pública voltada para a proteção dos monumentos e, mais especificamente, para o controle do comércio de antiguidades, estabeleciam-se as condições para o acúmulo de capital simbólico ${ }^{109}$ pelo MHN e por seu diretor no que se refere à liderança de uma rede nacional de agentes empenhados na construção de uma ideia de nação. Contribuía-se, dessa forma, para o fortalecimento da autoridade do $M H N$ e de seu diretor junto às atividades de colecionadores e negociantes de antiguidades, que poderia resultar em ganhos para o acervo, além do reconhecimento como referência para autenticar, avaliar e valorar objetos históricos e artísticos. Estavam lançadas as bases para que Barroso conquistasse uma centralidade no campo de produção do passado nacional no seio do Estado. A lei funcionaria como uma espécie de poder coercitivo para fazer valer sua autoridade.

Segundo Rafael Zamorano Bezerra, em seu estudo sobre os dispositivos de valoração dos objetos históricos no $\mathrm{MHN}$, "autoridade e poder não devem ser confundidos." . Enquanto o segundo relaciona-se com a "capacidade de fazer, ter permissão ou estar habilitado para fazer algo", a primeira "vem de auctoritas e significa ser gerador de qualquer coisa ou alguém, fonte ou origem, autor ou artífice". 110 Baseando-se nas reflexões de Hannah Arendt e Platão, Bezerra infere que uma forma de autoridade é o "conhecimento especializado [que] infunde confiança, de modo que nem a força nem a persuasão são necessárias para obter a aceitação dos homens". ${ }^{11}$ No caso em questão, Barroso e seus representantes,
107. Cf. Ministério da Educação e Saúde (1943, p. 42), grifo nosso.

108. Cf. Ministério da Educação e Saúde (1943, p. 42), grifo nosso.

109. Ver Pierre Bourdieu (1996, p. 107-114).

110. Cf. Rafael Zamorano Bezerra (2011, p. 226-7).

111. Cf. Rafael Zamorano Bezerra (2011, p.227). 
112. Cf. Pierre Bourdieu (1996, p. 113).

113. Cf. Secretaria de Estado da Educação e Saúde Pública (1934).

114. Cf. Brasil (1934). enfim o MHN, estão sob uma jurisdição que os favorecia, dotando-os de poder, no sentido de construir essa confiança em relação ao conhecimento especializado que possuíam junto à defesa dos monumentos como projeto de Estado, mais especificamente do Estado varguista. Tratava-se de uma nomeação por parte do Estado que o colocava numa "situação de autoridade", 112 que ainda se fortalecia com a existência do Curso de Museus, um lugar voltado para a produção e a disseminação desse tipo de autoridade especializada.

Não estava em jogo uma capitalização no sentido econômico para a instituição, haja vista que o artigo sobre as fontes de recursos da Inspetoria foi retirado e previa valores maiores do que os aprovados como pagamento de taxas, multas e honorários sobre autenticação e avaliação no regulamento final. Segundo a minuta, a Inspetoria estava prevista para se manter com os créditos concedidos pelo governo para atendimento das despesas básicas, mas também com recursos oriundos das multas de 50\$000 a 1:000\$000 aplicadas aos proprietários de imóveis que desrespeitassem as determinações do regulamento; da taxa de exportação de $300 \$ 000$ sobre objetos de valor histórico e artístico, cuja guia tenha emitido, serviço sobre o qual teria monopólio, e mais os valores obtidos por meio dos serviços de registros, peritagem, certidões etc.". ${ }^{113}$

Dois dias após aprovado o novo regulamento do MHN com a criação da IMN, foi promulgada a Constituição Federal de 1934, que trata do assunto pela primeira vez. Dedicava dois artigos ao tema da preservação. $\bigcirc$ de número 10 estabelecia que "compete concorrentemente à União e aos Estados: [entre outras medidas] III - proteger as belezas naturais e os monumentos de valor histórico ou artístico, podendo impedir a evasão de obras de arte."Já o artigo 148 determinava: "Cabe à União, aos Estados e aos Municípios favorecer e animar o desenvolvimento das ciências, das artes, das letras e da cultura em geral, proteger os objetos de interesse histórico e o patrimônio artístico do País, bem como prestar assistência ao trabalhador intelectual". ${ }^{114}$

\section{ENTRE A "CASA DO BRASIL" E A "CIDADE SAGRADA": A IMN (1934-1937)}

Amparado legalmente, Gustavo Barroso colocou a Inspetoria de Monumentos Nacionais em funcionamento. Uma das primeiras medidas tomadas foi a formação de um documentário iconográfico com imagens das cidades que preservavam grande número de remanescentes arquitetônicos dos tempos coloniais. Foram desenhos e aquarelas produzidos por Alfredo Norfini em viagens 
na década de 1920 e comprados pelo museu em $1934^{115}$ (Figura 5), bem como a encomenda de pinturas aos artistas José Wasth Rodrigues (Figura 6) e Hans Nobaver (Figura 7), que se dedicaram exclusivamente à reprodução de monumentos das cidades mineiras visados para os trabalhos do novo órgão, especialmente Ouro Preto. A coleção Norfini foi publicada no sétimo volume dos Anais do MHN, com comentários de Gustavo Barroso. ${ }^{116}$ Todas as obras foram compradas com dotação do MHN para aquisição de objetos históricos. Ou seja, embora relacionadas com as atividades da IMN, não foram adquiridas com recursos específicos deste departamento.

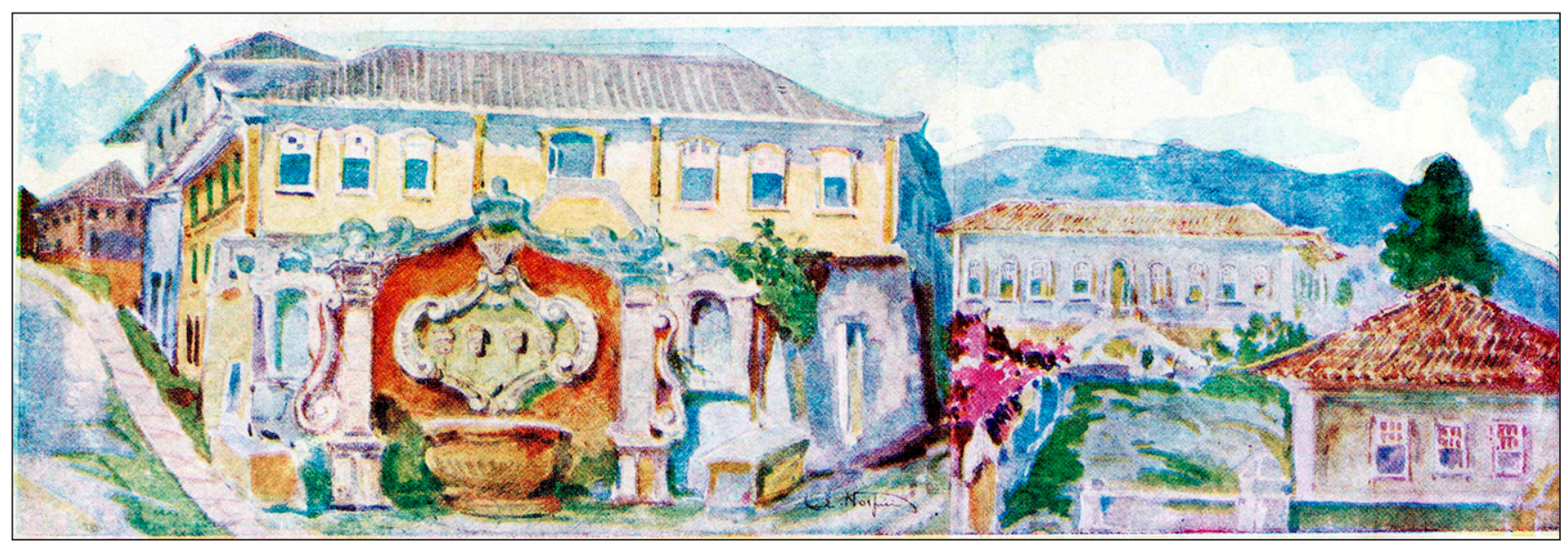

Figura 5 - Alfredo Norfini. Chafariz do Largo de Marília de Dirceu em Ouro Preto. 192?, aquarela, 44,8 × 14,3 cm. Acervo do Museu Histórico Nacional, Rio de Janeiro.

No relatório institucional de 1934, foi solicitada verba ao Ministério alegando a criação da terceira seção para o MHN, que se denominaria "Patrimônio Histórico". Afinal, tratava-se de um setor de "projeção nacional, não se limitava ao Rio de Janeiro. Obrigava a viagens, fiscalização local, locomoção urgente e incessante dos funcionários comissionados". ${ }^{117}$ Consta que a previsão era aplicar a verba na restauração de Ouro Preto, no ano seguinte.

Em 1935, foi enviado ao Ministro da Educação e Saúde um Plano de Restaurações, no qual constavam os monumentos da cidade de Ouro Preto carecidos de cuidados (templos, pontes e chafarizes), fazendo as devidas justificativas. Entre os principais motivos expostos para a realização das obras, estava o desejo de devolver aos monumentos suas feições primitivas, livrando-os dos "arranjos e consertos infelizes".

115. Ver Cf. Processo 14/34.
116. Ver Museu Histórico
Nacional (1953).
117. Ver Museu Histórico
Nacional (1934, p.2).

Em primeiro lugar, seria longa a tarefa, mas integral, um trabalho lento aliado a execuções criteriosas, em que, ao lado do carinho, viva o interesse principal em assemelhar as coisas 
118. Cf. Gustavo Barroso apud Museu Histórico $\mathrm{Na}$ cional (1944, p. 35), grifo nosso. velhas e gastas ao que eram originalmente; verdadeira obra de restauração, a primeira que se levaria a efeito no país, ligando-nos ao passado por laços imperecíveis. ${ }^{118}$

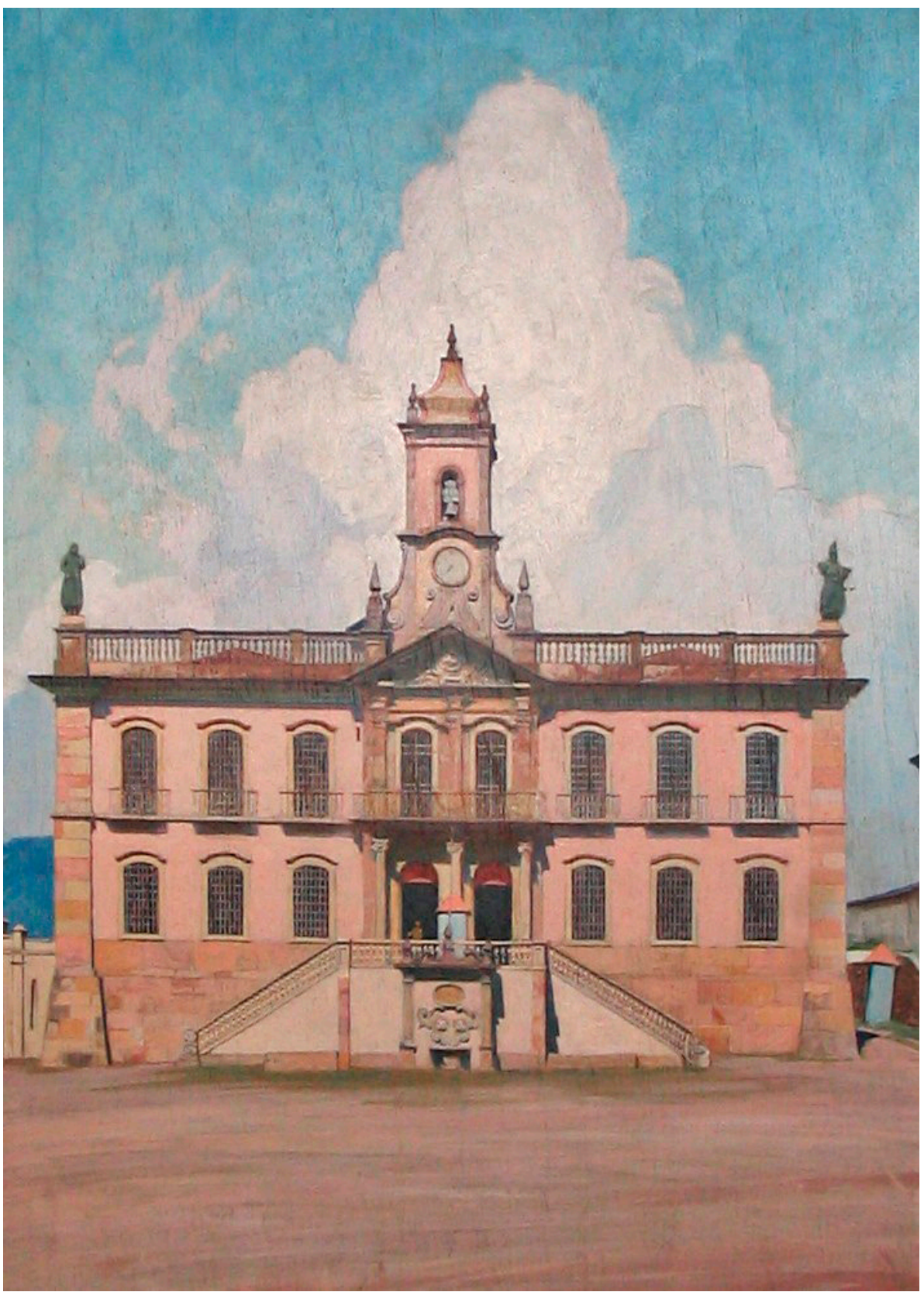

Figura 6 - Hans Nobauer. Antiga Cadeia de Ouro Preto, 1934, óleo sobre madeira, 64.20 x $49.50 \mathrm{~cm}$. Acervo do Museu Histórico Nacional, Rio de Janeiro. 


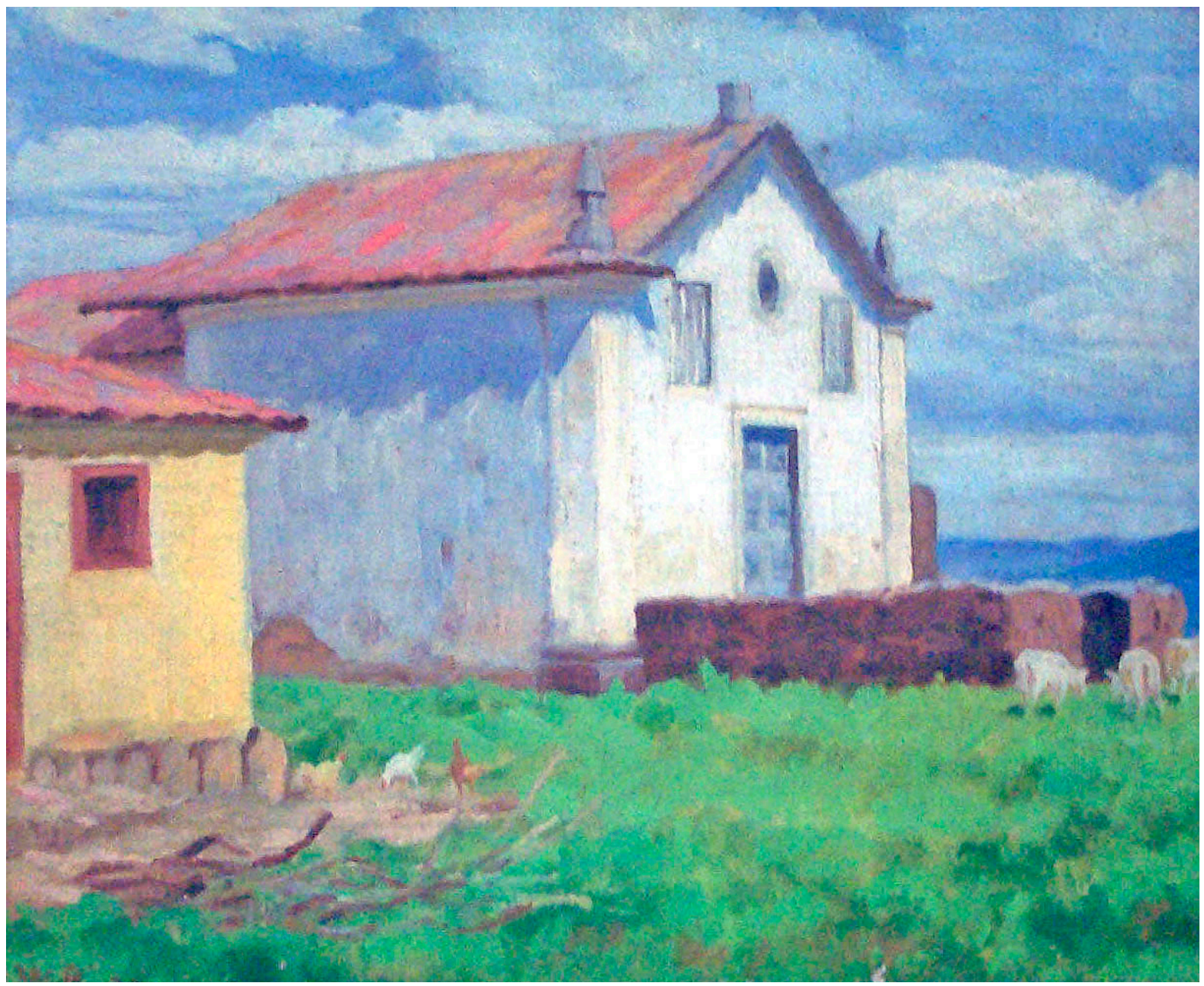

Figura 7 - José Wasth Rodrigues. Capela de São João em Ouro Preto, 1934, óleo sobre tela, 55 x 46 cm. Acervo do Museu Histórico Nacional, Rio de Janeiro.

Ao propor as atividades de preservação dos monumentos de Ouro Preto, Barroso buscaria dar continuidade às intervenções feitas entre 1928 e 1930, partilhando os preceitos estabelecidos por Viollet-le-Duc, segundo os quais era fundamental restaurar as edificações restabelecendo-as em seu estilo e funções. Afinal, o desejo era ligar o presente ao passado "por laços imperecíveis", sob uma perspectiva romântica de tornar o passado longínquo presente, mas fundamentado cientificamente. Daí a referência a uma ação "carinhosa", mas também "criteriosa". O critério seria estabelecido por meio da pesquisa iconográfica e da análise dos contratos de obras emitidos para efetivação das construções no século XVIII. ${ }^{119}$ Nessa perspectiva, Barroso procurava identificar os elementos que não correspondiam ao período das construções, comprometendo

119. Documentos expedidos pela Câmara Municipal de Ouro Preto aos arrematantes que se comprometiam com a realização de obras públicas. Nesses documentos havia as condições para efetivação do contrato e uma normatização técnica sobre como as obras deveriam ser feitas. Os "Contratos de Obras" analisados por Barroso referiam-se às obras públicas voltadas para facilitar a dinâmica das cidades, 
como o abastecimento de água para a população, a construção de pontes e o calçamento das ruas para melhor circulação. Atualmente, essa documentação se encontra no Arquivo Público Mineiro, em Belo Horizonte na seção Câmara Municipal de Ouro Preto. Os arrematantes faziam lances para a realização de uma construção em pregões. Quando ganhavam, investiam em melhoramentos urbanos tendo o retorno desses investimentos de forma parcelada. Ver Feu de Carvalho. (s.d., p. 36-44).

120. Ver Beatriz Mugayar Kühl (2000, p. 22).

121. Cf. Gustavo Barroso apud Museu Histórico Nacional (1944/1955, p. 35).

122. Cf. Gustavo Barroso apud Museu Histórico Nacional (1944/1955, p. 35).

123. Cf. Gustavo Barroso apud Museu Histórico $\mathrm{Na}$ cional (1944, p. 36). sua autenticidade. Propunha-se, então, a desfazê-las, a exemplo do procedimento de Viollet-Le-Duc na "desrestauração" da igreja de Saint-Sernin, na França, suprimindo as adições góticas para se chegar a um românico puro. ${ }^{120}$ Assim, servia-se das informações dos "Contratos de obras" para devolver às construções ouro-pretanas seu estado original.

Alterou-se a fisionomia da cidade com a implantação do calçamento a paralelepípedos, o que, entretanto, não constituiria crime, se aqueles que o executaram procurassem aproveitar a colaboração do que já existia. Assim não aconteceu: os níveis dos passeios das pontes foram violados sem uma razão de ordem técnica e muito menos utilitária e, então, as primeiras fiadas de lajes que iam servir de base aos parapeitos das pontes, que por sua função e recomendação nos "Contratos de Obras" não seriam aparelhadas, aparecem hoje como mostras de trabalhos imperfeitos. ${ }^{121}$

Barroso critica duramente as reformas feitas nas ruas da cidade por não terem sido fieis à técnica tradicional, ao que estava escrito nos "contratos de obras". Considerava esse procedimento um crime, por comprometer a aparência e a utilidade das edificações urbanas. Continua ele lamentando que a função das edificações, tão cara ao cotidiano da população no século XVIII, tenha sido transformada outra que desmerece sua importância:

Se atentarmos para o desfalque que têm sofrido estas pontes em suas peças de arte, chegaremos em breve a verdadeiras "pinguelas de alvenaria"[...] Os "assentos", que os "Contratos de Obras" exigiam fossem de lajes do Itacolomi bem aparelhadas, são hoje destinados a afiador de facas e canivetes, deixando de ser os descansos daqueles que, ao entardecer, procuravam as pontes para os comentários das coisas do dia [...] roubou-se a esses elementos a função importante de conter os bueiros, alguns bem trabalhados, escoadouros das águas que corriam nos passeios, e hoje vemo-los uns quebrados, outros entupidos e mascarados de capim e ao seu lado, feios, imperfeitos e sem critério de colocação, pedaços de canos de ferro longos, a desafiar àqueles na sua duração e utilidade. ${ }^{122}$

Repetidas vezes em seu planejamento, Barroso recorre aos "Contratos" para justificar suas intenções e criticar as reformas que modificaram os padrões estipulados. Era como se os acréscimos tivessem transformado as construções em outra coisa, sendo necessário reconstituílas em sua integridade de origem. Assim, em seu romantismo, abria-se uma possibilidade de reviver os tempos áureos da cidade, agindo como os habitantes daquele passado distante junto aos monumentos restabelecidos em sua aparência e funções.

Se lançarmos as vistas para baixo dessas pontes, então nos convenceremos cedo que mal andaram aqueles que as construíram numa obediência cega às "Condições de Contratos de Obras", parece que a preocupação atual é provar a inutilidade daquelas recomendações, que foram a razão exclusiva da permanência, até nossos dias, de todas as obras que nos fazem lembrar os dias opulentos de outrora. ${ }^{123}$ 
Se nessa fase de planejamento das atividades da Inspetoria os "contratos de obras" foram muito recorrentes - como forma de demonstrar o quanto a cidade necessitava de intervenções, provando a diferença entre o que se tinha e o que se deveria ter - nos relatos sobre as reformas realizadas eles foram pouco citados. A pesquisa afastou-se dos documentos escritos para os próprios monumentos, numa espécie de prática arqueológica em busca das estruturas originais a serem reconstituídas e da identificação dos materiais utilizados no ato das construções.

A execução dos serviços iniciou-se em finais de 1935, sob a direção do engenheiro Epaminondas de Macedo. A equipe da IMN reduzia-se a Gustavo Barroso como o inspetor, a Macedo como o engenheiro responsável pelo orçamento, pesquisas e obras, e a Angyone Costa, conservador do MHN que respondia pela IMN na ausência de Barroso.

Foi no relatório de atividades de 1935 que Barroso reivindicou para o Museu Histórico Nacional o título de Casa do Brasil, após citar as atividades do Curso de Museus e da Inspetoria de Monumentos Nacionais que, somadas às demais já realizadas anteriormente, tornavam o MHN um "estabelecimento padrão". Afinal, o Museu ampliava seu raio de ação contando com poucos recursos financeiros e um número reduzido de funcionários. Escrevia assim em sua conclusão: "Na sua estática - como o único museu histórico federal - e na sua dinâmica - como estabelecimento universitário de aperfeiçoamento dos estudos conexos com a história nacional - a esta Repartição cabe de direito o nome da Casa do Brasil". ${ }^{124} \bigcirc$ documento não apenas informa sobre o funcionamento da instituição por ele dirigida, mas procura convencer as autoridades de sua importância para a cultura nacional e, assim, conquistar o reconhecimento enquanto "Casa do Brasil".

No que se refere à Inspetoria de Monumentos Nacionais, foi comentado o recebimento da verba de 100:000\$000 e sua aplicação nas obras de restauração de monumentos de Ouro Preto iniciadas em dezembro daquele ano, junto com a nomeação de Macedo como representante do órgão na cidade, conforme notificou - jornal A Voz de Ouro Preto. ${ }^{125}$ No mesmo documento, enviado ao ministro da Educação e Saúde Pública, Barroso faz uma longa explicação sobre seu papel frente às ações da IMN:

Devo acentuar, relativamente a Ouro Preto, que a ação pessoal dessa diretoria foi decisiva para que ainda nos últimos meses do ano passado muito se fizesse, em reparos urgentes e completos, nas preciosas igrejas do Carmo, de Antônio Dias e em todos os chafarizes antigos e nas velhas pontes da cidade, tudo quanto era indicado pelo estudo de semi-ruína dos principais imóveis ali localizados. Conhecedor há longos anos de Ouro Preto, tendo em administrações passadas contribuído com desinteressado e profícuo esforço, para que fossem atacadas as obras indispensáveis no sentido da preservação de tais
124. Cf. Museu Histórico Nacional (1935, p. 10).

125. Ver Inspetoria de Monumentos Nacionais (1935). 
126. Cf. Museu Histórico Nacional (1935, p. 1-2), grifo nosso.

127. Ver especialmente os cadernos de recortes de jornais GB20-GB25 na Biblioteca do Museu Histórico Nacional. Gustavo Barroso integrou-se às fileiras do integralismo em 1933, após uma temporada entre França e Alemanha no período em que esteve afastado do Museu Histórico Nacional. Com militância mais próxima ao nazismo alemão pelo seu forte caráter antissemita, Barroso tornou-se uma das principais lideranças, ao lado de Plínio Salgado e Miguel Reale. Sobre o assunto ver Marcos Chor Maio (1992).

128. Numa carta de 13 de junho de 1935, João Velloso recomenda Epaminondas de Macedo a Gustavo Barroso para ser o responsável das obras em Ouro Preto. Este documento foi reproduzido no volume 5 dos Anais do MHN, "Documentário da ação do Museu...". Nessa versão, a palavra "integralizando" foi substituída por "entre". Cf.: Museu Histórico Nacional (1944/1955, p.20).

129. Cf. Museu Histórico Nacional (1944/1955, p. 132). riquezas artísticas, que pereceriam sem um imediato socorro, me senti animado de partida satisfação ao concluir as providências acima aludidas. Por minha designação, superintende aos mesmos trabalhos em Ouro Preto o engenheiro Epaminondas de Macedo, que em relatórios semanais traz esta diretoria a par do desenvolvimento de suas atividades segundo as minhas determinações. ${ }^{126}$

Com esse relato, Barroso procura sublinhar sua centralidade e autoridade nos trabalhos em Ouro Preto, o que não corresponde com a documentação relativa ao departamento hoje existente. A correspondência de Epaminondas de Macedo ao longo desse ano foi mais intensa com Angyone Costa, que não é citado no relatório, do que com Barroso. Esse esteve ausente em alguns períodos ao longo do ano, em função das campanhas integralistas Brasil afora, conforme se observa em sua coleção de recortes de jornais, na biblioteca do MHN. ${ }^{127}$

Quando soube que Barroso esteve em Minas, mas não passou por Ouro Preto, o prefeito João Velloso demonstrou, em carta, seu desapontamento com a demora da visita de Barroso para resolver assuntos da preservação dos monumentos ouro-pretanos. Assim escreveu ele:

Prezado amigo Dr. Gustavo Barroso, Minhas atenciosas saudações. Esperei que o Dr. passasse por aqui antes de regressar para o Rio pois o Sr. já me havia prometido vir brevemente a Ouro Preto para estudar as condições de conservação dos nossos monumentos artísticos. Lamento profundamente que assim não tenha sido e estou certo de que motivos imperiosos o impediram de o fazer [...]. Agora não sei quando terei a ventura de vê-lo aqui "integralizando" os nossos monumentos artísticos e nossas alterosas montanhas. ${ }^{128}$

Enquanto isso, Epaminondas de Macedo fiscalizava as obras em Ouro Preto e remetia relatórios para o Museu Histórico Nacional. Sobre o processo de reconstituição dos chafarizes, escreveu que foi realizado um trabalho de escavação arqueológica para encontrar, abaixo das mais recentes construções, a estrutura original dos tempos coloniais. Essa busca, realizada em parceria coma Escola de Minas, apresentou-se necessária também para identificar o material utilizado para sua edificação. Sobre a restauração do chafariz dos Contos, Macedo descreve:

Aberta a parede do lado esquerdo para pesquisar o paredão em esquadro a que se referem os documentos da época. Se bem que seja real ter existido, nada poderá fazer, porque do lado presumido se acha o prédio do Banco do Comércio, construído em 1889. 0 Chafariz foi levantado em 1765. Há vestígios da antiga casa de Manoel Rodrigues no fundo do Banco. Descobriu-se o antigo encanamento de água, em telhas, através do paredão de frente, bem como a pia de distribuição para as bicas, que se desentupiram, lavando-se a pia, de modo que agora a água está jorrando como outrora!. . 29 
Pelo relato de Macedo, percebe-se a dificuldade de encontrar no lugar de realização das obras os elementos arquitetônicos indicados na documentação escrita, em função das transformações pelas quais a cidade passou. Daí a ênfase na investigação do monumento e de sua estrutura segundo práticas arqueológicas. A restauração feita nos chafarizes da cidade, como o dos Contos, devolveu-lhes a suposta aparência e a utilidade, restaurando o que ainda restava e reconstituindo o que não existia mais, de modo a torná-los semelhantes ao que já teriam sido um dia. Para esse trabalho, foram utilizadas pedras retiradas do Itacolomi, chamadas itacolomito - as mesmas utilizadas para a construção de pontes e chafarizes do século XVIII. Acreditava-se que a reconstituição feita com materiais idênticos aos utilizados no ato da construção manteria a autenticidade do bem restaurado. Sobre esse aspecto, Epaminondas de Macedo relata a Gustavo Barroso, em um de seus relatórios semanais:

Examinada a massa branca que ligava as paredes do tanque, viu-se que se compõe de cal preta magra. A análise foi feita pela Escola de Minas. Em procura da cantaria necessária aos serviços, estive na aba do Itacolomi, no local em que foi explorada a pedreira para as obras que se fizeram antigamente em Ouro Preto e ali encontrei dispersos cerca de $10 \mathrm{~m}^{2}$ de lajes de itacolomito, devidamente aparelhadas. Essa cantaria será em breve transportada para a cidade. $\bigcirc$ achado nos deu material idêntico ao dos monumentos em via de restauração e preparado pelos seus próprios construtores. ${ }^{130}$

A preocupação com o material utilizado nas restaurações seguia uma prerrogativa leduciana ao "dar preferência ao uso de materiais iguais aos originais para reproduzir as formas primitivas [sendo] necessário seguir com rigor a lógica inicial das construções [...] com o arquiteto procurando colocar-se no papel do arquiteto primitivo". ${ }^{131}$ E para demonstrar como Macedo seguia as pistas deixadas pelo "arquiteto primitivo" no sentido de fazer como este fizera, foram produzidos relatórios com informações detalhadas sobre os procedimentos, enriquecidos com vasta documentação fotográfica. $\bigcirc$ fotógrafo local Luiz Fontana ( 1897-1968), 132 municiava a Inspetoria de Monumentos Nacionais com imagens das edificações antes, durante e depois das intervenções, ilustrando a fase de diagnóstico do estado físico das construções, as restaurações sofridas e os resultados finais dos trabalhos. Também registrava alguns desafios enfrentados pela IMN, como o processo de retirada e transporte de pedras do Itacolomi para - local das obras (Figuras 8 e 9).

Quando os trabalhos realizados no Chafariz de Marília, por exemplo, são divulgados no volume 5 dos Anais do MHN, são publicadas fotografias com legendas. Em uma delas há, como informação imprescindível: "Chafariz de Marília recomposto. As 4 carrancas restauradas e lançando água". ${ }^{133}$ Isso era fundamental
130. Cf. Museu Histórico Nacional (1944/1955, 132), grifo nosso.

131. Cf. Beatriz Mugayar Kühl (2006/ 2007, p. 131).

132. Embora não apareçam os créditos das imagens divulgadas junto aos relatórios publicados no volume 5 dos Anais do MHN, as fotografias foram identificadas na coleção Luiz Fontana disponibilizada no site da Prefeitura Municipal de Ouro Preto: $<$ http://www.ouropreto. mg.gov.br/luiz_fonta na_2015/>. Acesso em 17 abr. 2017. O MHN não preserva os originais utilizados na publicação; entretanto, foram encontradas em seu Arquivo Histórico outras fotografias do período com o carimbo de Luiz Fontana no verso, indicando a relação entre a Inspetoria e o fotógrafo. No carimbo, a inscrição "Ouro Preto Monumento Nacional" demonstra como o título concedido à cidade agregava valor aos seus registros. Para saber mais sobre Luiz Fontana, ver Alexandre Augusto de Oliveira(2006) e Alexandre Martins (1996).

133. Cf. Museu Histórico Nacional (1944, p. 153). 
134. Ver Stephen Bann (1984, p. 22). Esse autor utilizou o conceito de taxidermia para analisar a escrita da história de Ranke, no século XIX. Por meio de sua narrativa, Ranke tentou recuperar a ideia de vida no passado que era descrito, no sentido de dar a dimensão de como efetivamente esse passado teria acontecido. Dar o sentido de vida ao passado que já estava morto, a partir das possibilidades de imaginação que sua escrita permitia, foi visto por Bann como um trabalho de taxidermia, que, vivenciando o luto pela morte do passado como experiência, altera a realidade para que o passado possa parecer vivo. Nessa perspectiva, é possível inferir que Barroso, vivenciando o luto pela morte do passado como experiência, interfere na realidade, ao preservar os vestígios materiais e devolvê-los à sua função original. Desta forma, faz parecer vivo o que não existia mais: o passado. para ilustrar o trabalho da Inspetoria no retorno da utilidade do chafariz, "como nos tempos coloniais" (Figura 10). Devolver água aos chafarizes era como devolver vida a algo que se encontrava morto, uma vez que sua utilidade original era restabelecida. Da mesma forma que um taxidermista interfere no que restou de um animal morto por meio de técnicas como o empalhamento, a fim de the conservar a aparência de como se vivo estivesse, Macedo interferiu nos vestígios do passado como uma possibilidade de thes devolver a vida. ${ }^{134}$

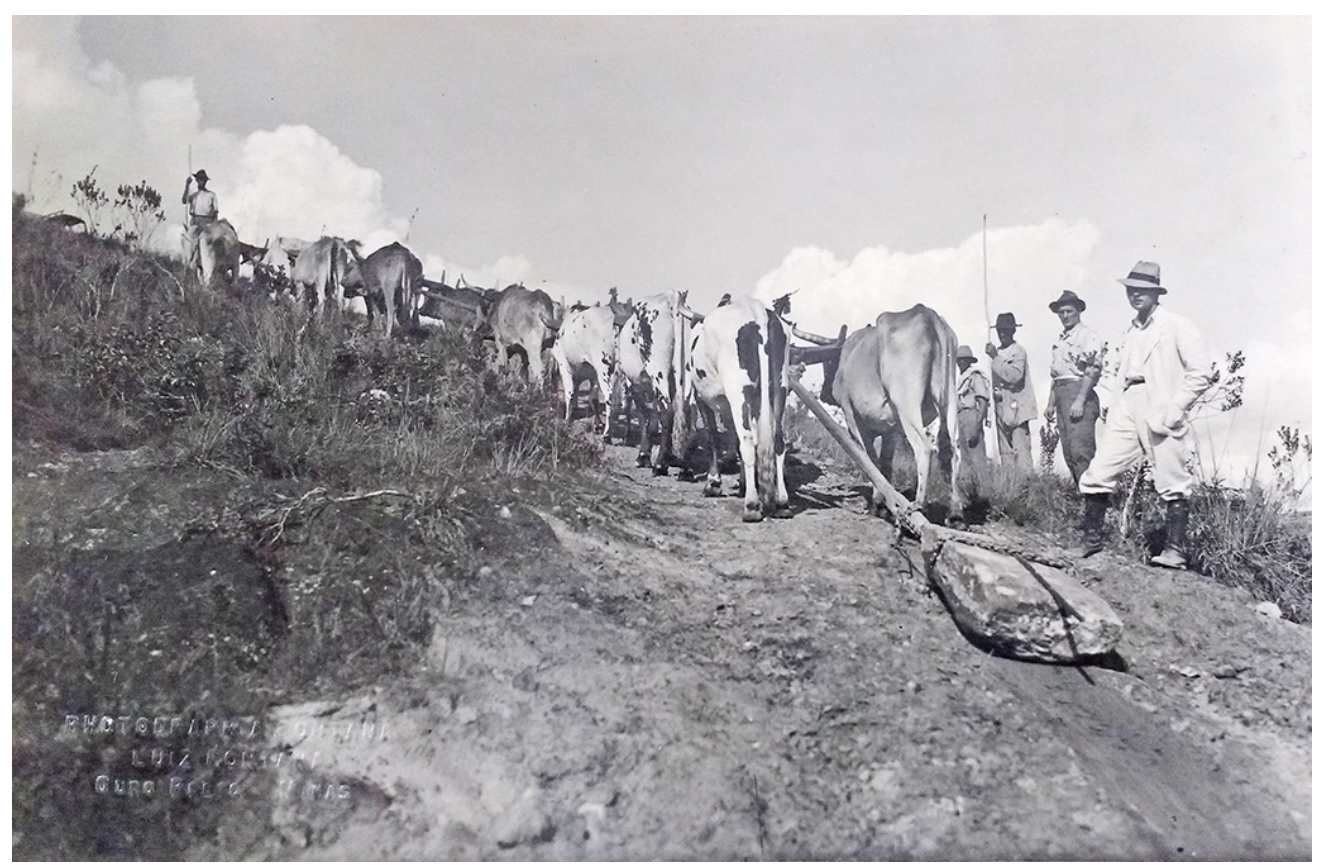

Figura 8 - Transporte de pedra da aba do morro Itacolomi para Ouro Preto, 1936. Fotografia de Luiz Fontana. Acervo do Museu Histórico Nacional, Rio de Janeiro.

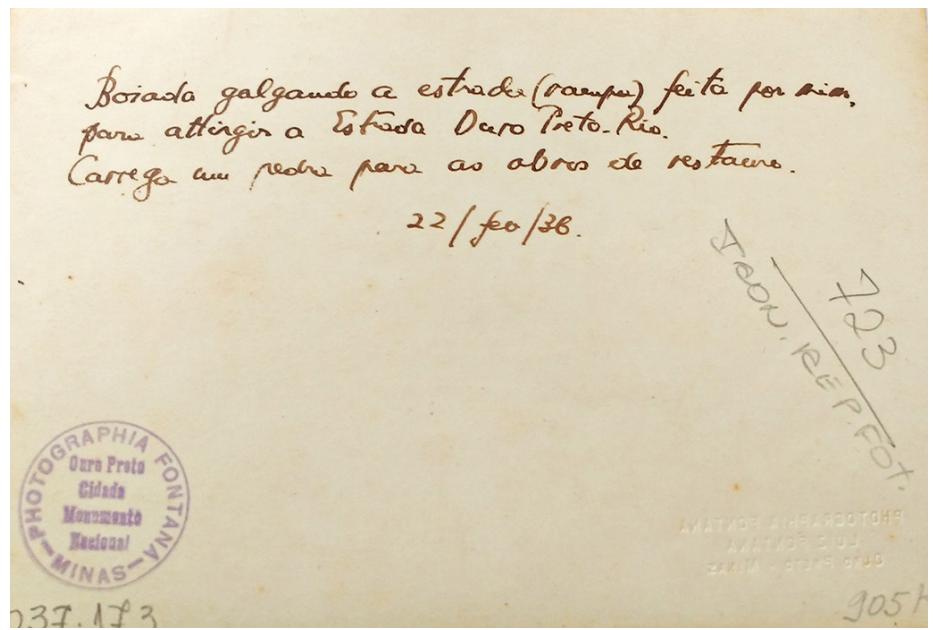

Figura 9 - Explicação de Epaminondas de Macedo sobre situação retratada: "boiada galgando a estrada (rampa) feita por mim, para atingir a Estrada Ouro Preto-Rio". Carrega uma pedra para as obras de restauro. 22/02/1936. Fotografia de Luiz Fontana. Acervo do Museu Histórico Nacional, Rio de Janeiro. 


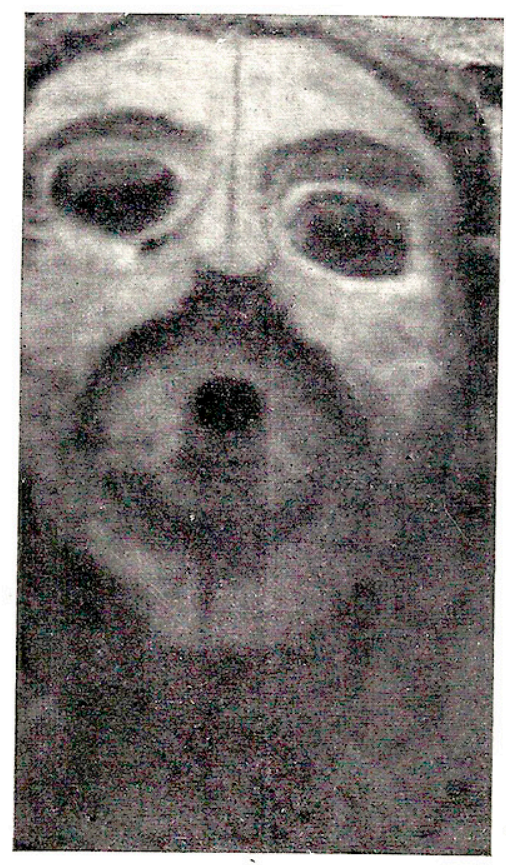

Chafariz de Marilia. Restos duma das 4 carrancas.

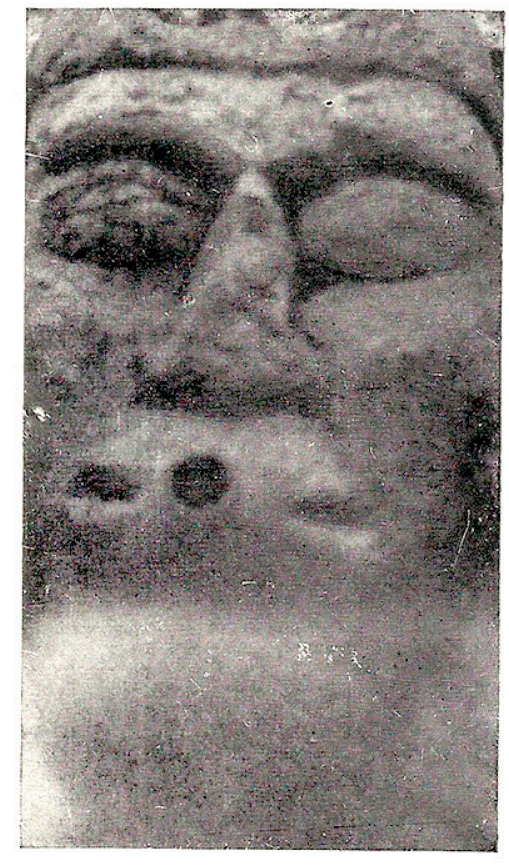

Chafariz de Marília. Estado de ruína duma das carrancas.

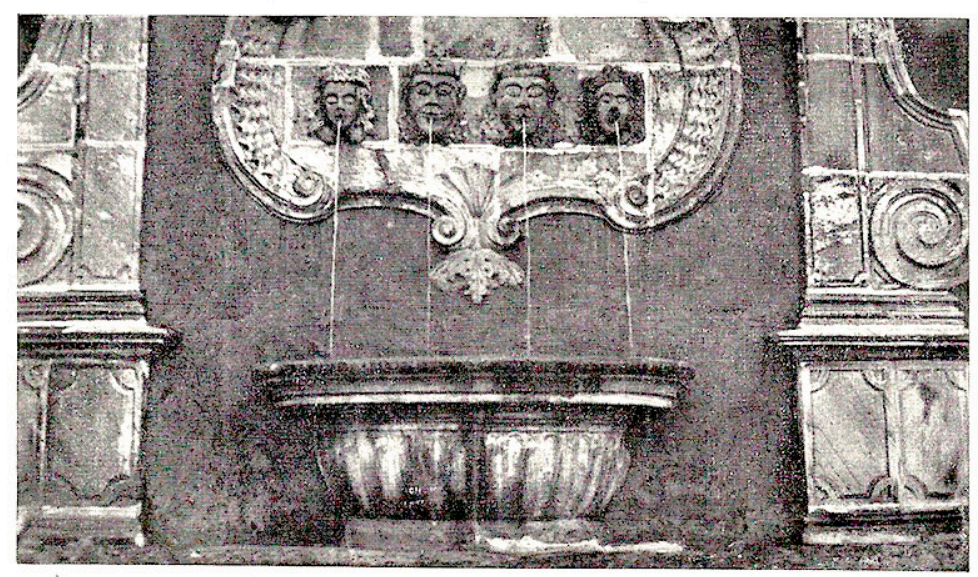

Chafariz de Marília, recomposto. As 4 carrancas restauradas e lançando água.

Figura 10 - Página 153 do volume 5 dos Anais do Museu Histórico Nacional, com detathes do Chafariz de Marilia antes da restauração e a imagem do mesmo após a restauração. Atenção para as legendas. Reprodução da autora. 
135. Cf. Museu Histórico Nacional (1944, p. 158), grifo nosso. A observação é uma crítica aos trabalhos realizados, possivelmente, pelo Serviço do Patrimônio Histórico e Artístico Nacional (SPHAN) que substituiu a IMN, em 1937.

136. Ver Carta de Atenas (1931).
Além do restabelecimento de seu uso primitivo, houve também uma intervenção para que a aparência do chafariz fosse reconstituída conforme teria sido quando construído. Foi realizada a subtração de um elemento que comprometia seu aspecto. Segundo Macedo: "Solicito resposta sobre o coroamento do chafariz de Marília, de acordo com o que mostra a fotografia ampliada que remeti". Como comentário dessa carta de Macedo, consta no Documentário: "Tratava-se dum coroamento falso que tinha sido no decurso do tempo posto no Chafariz. A Inspetoria autorizou o encarregado da obra a tirá-lo. Hoje fizeram outro. Tão falso quanto o anterior". ${ }^{\prime \prime 3}$

A restauração das pontes também foi feita dentro dos padrões de escavação para identificação das estruturas originais e sua reconstituição, pondo abaixo os elementos acrescidos posteriormente à construção das edificações. Essa prática, presente nas intervenções leducianas, era condenada pela Carta de Atenas de 1931, que recomendava a conservação dos acréscimos, quando esses possuem valor histórico ou artístico, seja qual for a sua época. ${ }^{136}$ Mesmo com o conhecimento das determinações internacionais, atuando junto à Comissão Internacional dos Monumentos Históricos a partir de 1934, Barroso autorizou a retirada da grade que havia sido colocada na Ponte dos Contos (originalmente denominada Ponte São José), no século XIX, sob a alegação de que feria a originalidade do monumento. Ou seja, não se reconhecia valor histórico ou artístico em nada que não fosse produzido no momento da construção. Assim, a Ponte dos Contos juntamente como a ponte de Antônio Dias, voltaram a dispor de banco e cruzeiro, de modo que todos os seus elementos voltaram a desempenhar sua função. Os bueiros foram desentupidos para o escoamento da água, e os assentos foram reconstituídos para que a população voltasse a sentar na ponte para descansar e conversar, como se fazia no século XVIII (Figuras 11 e 12).

Em 1903, Alois Riegl já criticava esse tipo de tratamento que, fundamentado no valor histórico dos monumentos, a eles imprimia o valor de novidade por meio das restaurações. Essa prática, recorrente no século XIX a exemplo do que foi realizado por Viollet-Le-Duc, deveria ser superada no que foi denominado "culto moderno dos monumentos". Segundo Riegl:

Dado que o valor histórico assenta no conhecimento claro do estado original, assim sugeriu-se, numa época em que o culto do valor histórico em função de si próprio fora muitíssimo decisivo, a tendência de eliminar todas as modificações posteriores llimpeza, desentulhamento) e restaurar as formas originárias que foram suplantadas por tais modificações [...] A esta tendência do culto do valor histórico liga-se a do valor de novidade, na medida em que o original que se pretendia restaurar deveria como tal mostrar um aspecto coeso e em que se sentia qualquer intervenção desadequada ao estilo original como uma interrupção a coesão, um sintoma da dissolução. Resulta daí o postulado da unidade es- 


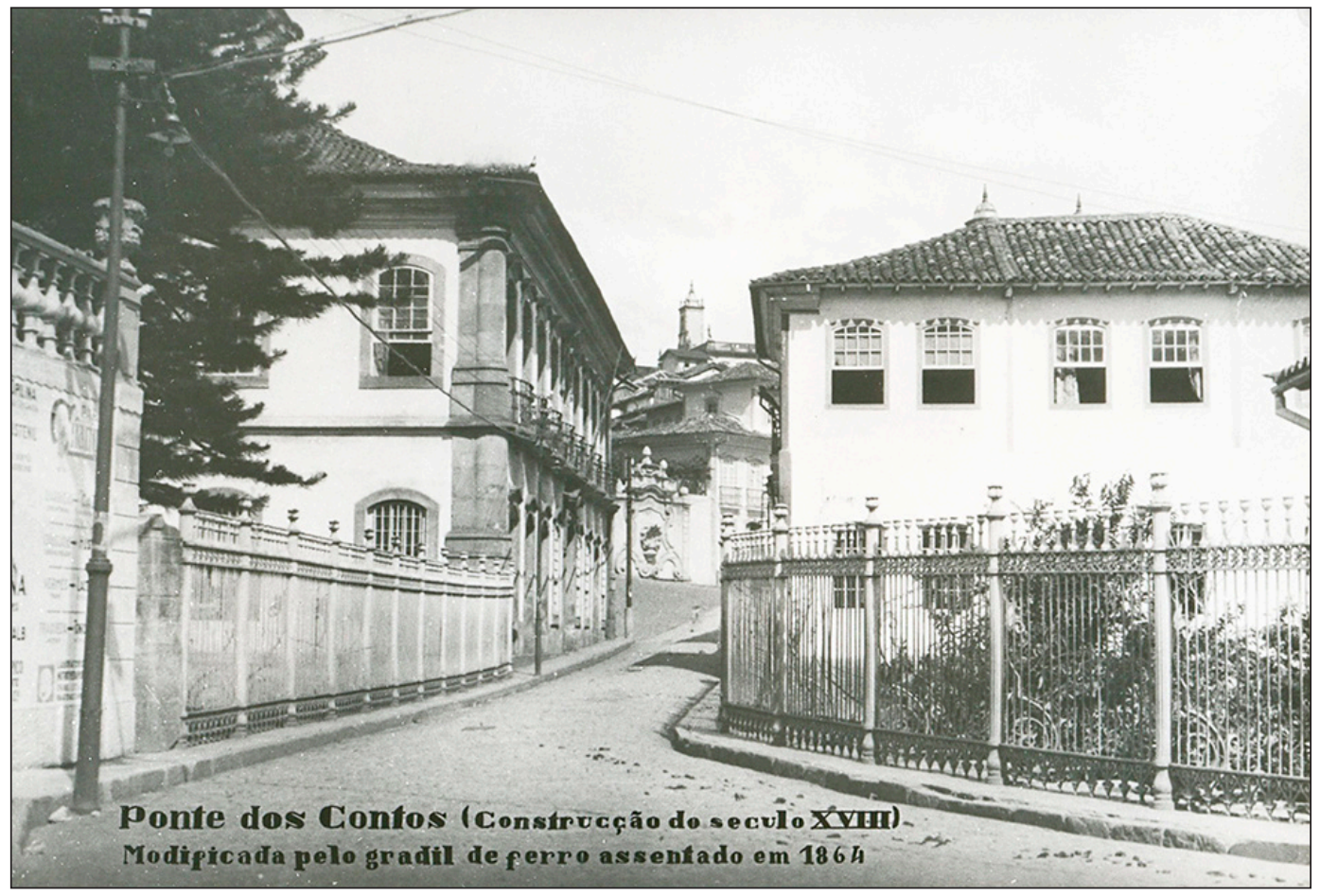

Figura 11 - Ponte dos Contos antes das intervenções da IMN, s/d. Fotografia de Luiz Fontana. Acervo do Arquivo Central do IPHAN, Seção Rio de Janeiro.

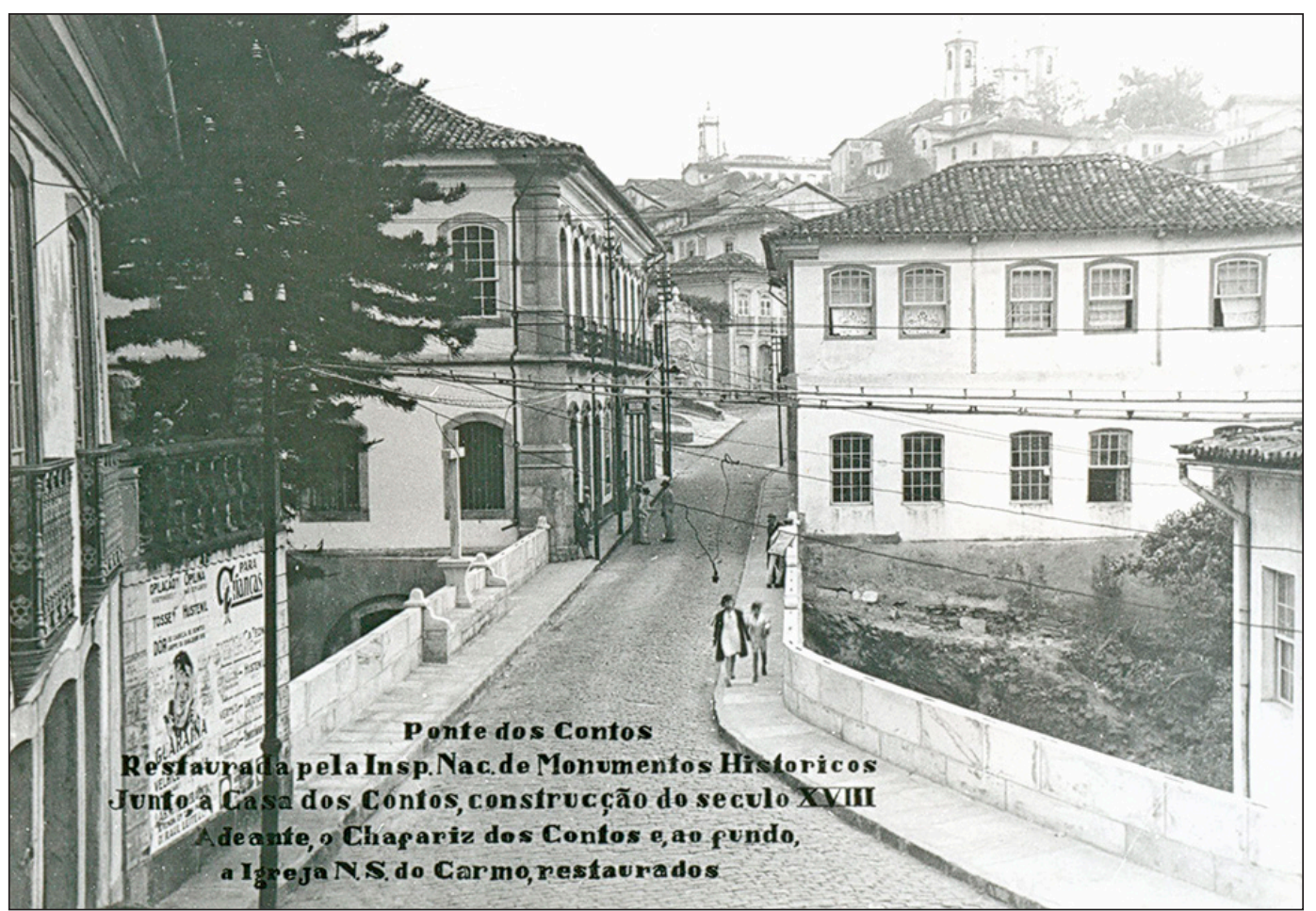

Figura 12 - Ponte dos Contos após intervenções da IMN. Fotografia de Luiz Fontana. Acervo do Arquivo Central do IPHAN, Seção Rio de Janeiro. 
137. Cf. Alois Riegl (2013, p. 53-4)

138. Cf. Gustavo Barroso (1943, p. 579), grifos nossos.

139. Cf. Limpar fachadas, (1921), grifo do autor. Nota sem assinatura com autoria atribuída a Gustavo Barroso por ter sido recortada e colada no caderno produzido pelo próprio, GB08, na biblioteca do MHN.

140. Cf. John Ruskin (1903, p. 68), grifos nossos. tilística que levou por fim a que não apenas se eliminassem aquelas partes que não existiam originalmente e só foram acrescentadas num período estilístico posterior, completamente novo, como também a que as renovações se fizessem de forma adaptada ao estilo do monumento original. Pode-se dizer com razão que o tratamento dos monumentos no século XIX se estribou nos postulados da originalidade estilística (valor histórico) e unidade de estilo (valor de novidade) ${ }^{137}$.

Vale lembrar que Gustavo Barroso chegou a criticar os trabalhos de Violletle-Duc ao citar sua "campanha de consagração e restauração, embora não perfeita, dos monumentos góticos". ${ }^{138} \mathrm{Em}$ verdade, Barroso afinava-se com uma postura mais romântica do século XIX quando denunciava intervenções em edificações antigas, que comprometiam as marcas do tempo. É o que podemos identificar em sua crítica aos trabalhos do prefeito Carlos Sampaio no Rio de Janeiro, em 1921:

Aqui - como em todo o país novo, pretensioso, ignorante, sem gosto e sem amor à tradição-tudo tem que ser polido, lavado, esfregado, areado, de modo que a cidade jamais conseguirá o aspecto solene das capitais europeias. Aqui se declarou guerra feroz ao mugre, à pátina. Quando o tempo doura as pedras dos edifícios ou as sombreia de roxo e negro, o prefeito manda esfregá-las. Quando os anos esverdeiam as estátuas, faz ensaboá-las. Dizem que é horror ao sujo. É simplesmente besteira... [...] Até parece que o Carlos Sampaio nunca esteve em Paris... ou, se esteve, não viu. ${ }^{139}$

Barroso pregava o respeito às marcas do tempo, tendo por referência o aspecto antigo das edificações que formavam a paisagem urbana das principais capitais europeias. Era uma forma de conceder à cidade o aspecto "civilizado" que a aproximaria daquelas do Velho Mundo. Nessa perspectiva, - inclusive na atribuição do valor sagrado à Ouro Preto e na pregação do culto da saudade Barroso está em sintonia com o pensamento romântico "antirrestauração" de John Ruskin, segundo o qual:

a maior glória de um edifício não está em suas pedras, ou em seu ouro. Sua glória está em sua ldade. [...] Está no seu testemunho duradouro diante dos homens, no seu sereno contraste com o caráter transitório de todas as coisas, na força que - através da passagem das estações e dos tempos, e do declínio e nascimento das dinastias, e da mudança da face da terra, e dos contornos do mar - mantém sua forma esculpida por um tempo insuperável, conecta períodos esquecidos e sucessivos uns aos outros, e constitui em parte a identidade, por concentrar a afinidade, das nações. É naquela mancha dourada do tempo que devemos procurar a verdadeira luz, a cor e o valor da arquitetura". ${ }^{140}$

Foi apenas em 1945, quando publicou seu livro Introdução às técnicas de museus, que Gustavo Barroso sistematizou os conceitos e as práticas de conservação e restauração arquitetônicos. $\bigcirc$ tema foi abordado no quinto capítulo da obra, denominado "Como se fazem restaurações". Tanto a restauração de monumentos, 
quanto a de objetos "estão na dependência dos mesmos conhecimentos técnicos e empíricos de ordem geral, que poderão obedecer aos seguintes itens: a) Doutrina. b) valorização. c) Técnica". ${ }^{141}$ No que diz respeito especificamente a monumentos, descreve três "escolas":

A primeira, mais antiga de todas, decorre das restaurações empreendidas por Viollet-le-Duc em França e dos trabalhos de Ludovic Viet, em 1831. É a escola da unidade do estilo, muito preconizada na Espanha moderna. Ela entende que se deve repor o monumento ou o objeto no seu absoluto estado primitivo, eliminando o que the foi ajuntado, refazendo de todo as partes danificadas, restaurando-o integralmente. A segunda, conhecida sob o nome de escola italiana, respeita o espírito do monumento ou do objeto criado através do tempo, conservando os valores que foi adquirindo, incorporando, sem aquela preocupação da unidade do estilo na sua pureza inicial. Enfim, a terceira, escola eclética, atualmente a mais admitida, que se bate por uma restauração fiel ao mais rigoroso critério de conservação [...] respeitando o que o tempo imprimiu e deixando visíveis as partes renovadas, como prova de probidade. Aliás, é o que oficialmente concluiu a Conferência de Atenas realizada sob a égide da Repartição Internacional de Museus da Sociedade das Nações: "No caso em que seja indispensável a restauração, por motivo de deterioração ou destruição, recomenda-se respeitar a obra histórica e artística do passado, sem proscrever o estilo de qualquer época". ${ }^{142}$

Interessante notar o reconhecimento dos princípios da Carta de Atenas como os mais admitidos, a exemplo da defesa de uma higiene preventiva para que não haja necessidade de restauração e a preservação da pátina "que é a assinatura do tempo", 143 em paralelo a um silêncio em relação às atividades da Inspetoria de Monumentos Nacionais. Os trabalhos realizados em Ouro Preto não são citados nas explicações. $\bigcirc$ exemplo de restauração apresentado por Barroso foi o do Castelo de Guimarães, em Portugal, com imagem acompanhada da seguinte legenda: "Castelo de Guimarães, em Portugal (do século X), restaurado pelo Governo Português: veem-se as reconstituições em pedra mais clara, mostrando as partes que foi preciso acrescentar ao conjunto pela força da necessidade". ${ }^{144}$ A ausência da IMN nas páginas do livro pode ser vista como a consciência do autor da distância entre a teoria baseada no documento internacional de 1931 e o que se fez junto aos monumentos de Ouro Preto poucos anos depois.

Para cumprir seu planejamento, a equipe da Inspetoria contou com algumas adversidades. As chuvas de janeiro de 1936 atrasaram o andamento de algumas obras, como a do Chafariz dos Contos. Alguns desentendimentos entre Barroso e autoridades locais também contribuíram para dificultar o andamento dos trabalhos. Epaminondas de Macedo, em seu relatório de 10 de setembro de 1936, informava que, para dar início às atividades de restauro na lgreja de São Francisco de Assis, estava apenas aguardando a saída do ministro da Irmandade, Marco Túlio Gramiglia, arquiteto e autor do projeto do cemitério que ficaria ao lado da igreja.
141. Cf. Gustavo Barroso (1951, p. 83).

142. Cf. Gustavo Barroso (1951, p. 84).

143. Cf. Gustavo Barroso (1951, p. 87).

144. Cf. Gustavo Barroso (1951, p. 85). 
145. Cf. Marco Túlio Gramiglia (1935).

146. Cf. Gustavo Barroso (1935a).
Em 1935, quando Barroso visitou Ouro Preto como Inspetor de Monumentos, reprovou o projeto, embargou a obra e ordenou a demolição do que havia sido construído. Depois dessa atitude de Barroso, Gramiglia estava disposto a dificultar a ação da Inspetoria. O referido desentendimento aparece na troca de correspondência entre Gramiglia e Barroso:

Meus parabéns sinceros pelo assunto que apreciei na vossa conferência de hoje. [...] Espero uma vossa solução sobre o plano a executar-se na igreja, ou seja no adro da lgreja de São Francisco de Assis. [...] Apesar de ser eu [Gramiglia] o projetista [do cemitério] teve a aprovação das autoridades civis e eclesiásticas e portanto obedeci às ordens emanadas e com os respectivos consentimentos. [...] A Ordem com a demolição e remodelação do serviço executado e a executar vai de encontro a um prejuízo não pequeno. Em ser prejudicado, posso me conformar, mas não posso conformar-me em prejudicar as pessoas que de boa vontade me auxiliaram com as suas dádivas. Portanto espero da vossa leal e justiceira pessoa uma solução satisfatória. ${ }^{145}$

Em resposta à carta que me dirigiu em Ouro Preto, a 17 do corrente, tenho a dizer-the que a Inspetoria de Monumentos Nacionais não pode dar uma aprovação ao plano de obras a que o Sr. se refere por entender que o mesmo fere a estética e a tradicionalidade da venerável e maravilhosa igreja de São Francisco de Assis [... não bastariam, às transformações projetadas pelo Sr., as autorizações que alega das autoridades eclesiásticas e civis, desde que iniciou obras sem prévia consulta a esta Inspetoria e sem seu assentimento. Reconhecendo embora seu esforço [...], a Inspetoria não aprova por muitas e boas razões o seu plano, o que já the notificou em caráter pessoal, sugerindo outro que não fere as linhas perspectivas e a harmonia do notável templo ouropretano. Chamo sua atenção para citar o art. 79, que prevê multa caso o regulamento não seja cumprido e o art. 78 do mesmo regulamento. ${ }^{146}$

Segundo o que indica a carta, a Inspetoria não havia obtido ainda o reconhecimento de sua autoridade em Ouro Preto. Para Gramiglia, era suficiente que as autoridades religiosas e civis locais aprovassem seu projeto para que a construção do cemitério fosse implementada, não se obrigando a uma consulta com a divisão dirigida por Barroso. Entretanto, com base no regulamento do Museu Histórico Nacional, a construção do cemitério foi impedida.

Outra divergência aconteceu entre Gustavo Barroso e Vicente Racioppi, que falava em nome do Instituto Histórico de Ouro Preto. Racioppi desejava atuar diretamente na preservação dos monumentos da cidade por meio do IHOP. Não conseguindo apoio nem reconhecimento das autoridades para essa função, passou a interferir nos trabalhos da IMN. Começou com sua tentativa em dar um direcionamento diferente às ações preservacionistas, propondo a criação de uma comissão da qual faria parte, e sugerindo outra destinação à verba de 100 contos de réis que a Inspetoria dispunha para realização de suas atividades: 
Tenho o prazer de comunicar a V. Excia. que em ofício desta data, 864, ao Senhor Presidente da República e em ofício n. 62, de 2 de dezembro último, ao Senhor Ministro da Educação e Saúde Pública, pedi que a verba de 100:000\$000, consignada no orçamento federal para 1935, art. 7 n. 8, ao MUSEU HISTÓRICO 'para conservação das obras artísticas e históricas da cidade de Ouro Preto (Monumento Nacional)' (verba n. 6), tenha aplicação por intermédio de uma comissão de representantes, que forem nomeados, dos governos federal, estadual, municipal e eclesiástico, controlada ainda por outra comissão, também nomeada pelo Governo Federal, de técnicos - um historiador, um arquiteto-urbanista, um pintor e um escultor - com a colaboração deste INSTITUTO HISTÓRICO, incumbido pelo Ministério do Exterior de importante pesquisa relativa a conjurados sepultados na Guiné Portuguesa e cujas ossadas foram exumadas como pertencentes a inconfidentes de 1789. [...] Foi prometida a metade desse dinheiro à Prefeitura Municipal local para pagamentos de despesas próprias, em desacordo com a destinação orçamentária. Cometem-se constantes atentados à arte religiosa e arquitetônica na cidade, só a comissão técnica poderá defender efetivamente, sob pena de se burlar, como burlado está sendo, o dec. 22.928, de 12 de julho de 1933, que elevou a cidade a MONUMENTO NACIONAL. ${ }^{147}$

Afirmando ter se dirigido a autoridades superiores à IMN, Racioppi demonstra insatisfação com a criação da repartição no MHN. Ao que parece, desejava cumprir as funções do órgão sediado no Museu Histórico Nacional por meio do Instituto que dirigia. Barroso responde à carta alegando que não há motivo para redirecionar a verba destinada à Inspetoria:

Devolvendo o incluso processo n. 1 1.01 1/35, da Diretoria da Despesa Pública do Tesouro Nacional, passo a informar a respeito da pretensão que originou, do Secretário do Instituto Histórico de Ouro Preto, pedindo seja a verba de 100 contos atribuída a obras de conservação daquela cidade mineira preservada da aplicação inconveniente. [...] Não há motivo para esse apelo. Constitui uma falsidade a alegação de estar 'prometida' metade da citada verba à Prefeitura de Ouro Preto. Incluindo-se a dotação orçamentária em questão na verba material do Museu Histórico Nacional como uma de suas sub-consignações, a esta Repartição técnica, de acordo com o Código de Contabilidade e com o dec. do Governo Provisório n. 24.735, de 14 de Julho de 1934, é que incumbe realizar os trabaIhos previstos e a despesa respectiva. Neste mesmo sentido requisitei, por ofício n. 36 de 16 de fevereiro p.p., a importância de 25:000\$ em adiantamento, afim [sic] de, quanto antes, executar o Museu Histórico parte do seu programa de defesa dos monumentos histórico-artísticos na cidade de Ouro Preto. [...] Sendo assim, não há necessidade para qualquer providência requerida pelo Sr. Vicente de Andrade Racioppi, secretário do Instituto Histórico de Ouro Preto. ${ }^{148}$

Racioppi insistiu no assunto das verbas em carta posterior, quando lamenta o não comparecimento de Gustavo Barroso, conforme havia combinado, à Casa de Gonzaga, onde funcionava o $\mathrm{HOP}_{\mathrm{P}}$, e atualmente abriga o Arquivo Municipal:

Pena foi que não tivesse vindo. Verificaria o espantoso desenvolvimento do Museu; leria a opinião escrita dos arquitetos Luiz Signorelli e Raul Lino contra as modernizações em redor
147. Cf. Vicente Racioppi (1935).

148. Cf. Museu Histórico Nacional (1935). 
149. Cf. Instituto Histórico de Ouro Preto (1935).

150. O historiador Daryle Williams analisou as tensas relações entre Racioppi, "um preservacionista local" e os agentes oficiais do Estado dedicados à preservação do patrimônio ouro-pretano, especialmente os técnicos do Serviço do Patrimônio Histórico e Artístico Nacional a partir de 1937. Ver Daryle Williams (2003).

151. Ver Eponina Ruas (1964).

152. Cf. Eponina Ruas (1935).

153. Cf. Gustavo Barroso (1935b), grifos nossos. da Capela de São Franco. de Assis e verificaria que a CASA DE GONZAGA é o único prédio da União, monumento arquitetônico e de história legado pelos nossos antepassados, que é por mim zelado e conservado à minha custa, há anos. A Escola de Minas e a Casa dos Contos são os outros dois prédios federais conservados com grossas verbas. (...) Nunca procurei receber da União o que despendi nesta CASA DE GONZAGA. Agora porém, que há para CONSERVAÇÃO DE OBRAS ARTÍSTICAS E HISTÓRICAS a verba de 100:000:000 [metade da consignação da IMN], pretendo que a União faça à sua custa, no seu único prédio em Ouro Preto sem assistência pecuniária, as obras de reparo do muro que ameaça ruínas, de parte do telhado e de renovação dos condutores apodrecidos de água do pátio interno. [...] Não tendo o ilustre amigo vindo ver este monumento de arte e de história, estou requerendo do governo tal serviço urgente de conservação. ${ }^{149}$

Segundo a carta, Racioppi não apenas se queixava da ausência de Barroso na cidade, como requeria parte dos recursos da IMN para empregar nas obras do edifício histórico onde instalou o $H O P$, a sua moradia e o seu escritório de advocacia. $\bigcirc$ edifício não constava no planejamento da IMN e não recebeu cuidados, mas a querela entre Racioppi e os agentes de preservação federais continuou para além da existência da Inspetoria. ${ }^{150}$ Outra personagem local que tentou interferir no destino das verbas da IMN foi a médica e farmacêutica Eponina Ruas, que viria a escrever livros e guias turísticos sobre Ouro Preto. ${ }^{151}$ Escrevia ela a Barroso em 14 de março de 1935:

Ontem, conversei com o Dr. Veloso que me relatou o que aqui se passava com relação a verba dos 100 contos e nesse momento relembrei-the um pedido que é uma necessidade de que se atenda: é a limpeza e conservação de uma casa da rua da Glória junto ao chafariz, a única que apresenta a nossa cidade em estilo mourisco [...] Esta casa está em ruínas, é de uma viúva pobre, e o ano passado restaurei todo o telhado que estava prestes a desabar [...] como ouropretana presto um dever que assiste a todos nós, filhos da velha Terra de Albuquerque. ${ }^{152}$

Barroso responde prometendo atenção ao pedido. Entretanto, não reitera o caráter singular da casa, tão sublinhado por Ruas:

"Recebi vossa carta do dia 14, cujo assunto mereceu a melhor atenção [...] Agradeço-vos o interessante informe, relativamente a uma preciosa casa colonial, entre tantas de Ouro Preto, que está a desafiar os cuidados de uma pronta restauração. [...] Pessoalmente espero dar as providências que sugere, nos termos da conversa que aqui tive com o nosso distinto e venerando amigo Dr. Velloso, pois não pouparemos esforços afim de bem acorrermos em defesa do patrimônio histórico e artístico dessa cidade, hoje sob especial proteção do Governo brasileiro". ${ }^{153}$

O relatório de atividades de 1936 inicia com a informação de que Barroso se manteve à frente do MHN e da Inspetoria de Monumentos. Mesmo sendo a segunda um departamento do primeiro, parece ser tratada como um órgão à parte. 
Acumulando essas funções, seu diretor realizou viagens de inspeção de monumentos a Ouro Preto, Mariana, Tiradentes e São João Del Rey. Informa também que a IMN aplicou a verba de 50:000\$000, destinada pela lei orçamentária, na conservação e restauração de obras antigas em Ouro Preto, sendo a reforma completa de duas igrejas, duas pontes e cinco chafarizes; a restauração parcial de dois templos e o planejamento do conserto do teto da Matriz de N. Sra. das Dores. ${ }^{154}$

No ano seguinte, a IMN desapareceu do relatório institucional. Sabe-se que, até o final de 1937, a repartição ainda realizou trabalhos em outros monumentos da cidade de Ouro Preto. Pela listagem publicada por Adolpho Dumans no livro A ideia da criação do Museu Histórico Nacional, contam-se o total de 33 monumentos, entre restauração total, parcial e realização de projeto. ${ }^{155}$ Pelos relatórios enviados por Epaminondas de Macedo, chegaram a receber os cuidados da Inspetoria 20 edificações, entre templos, pontes e chafarizes. ${ }^{156}$

Nesse mesmo ano, a IMN foi substituída pelo Serviço do Patrimônio Histórico e Artístico Nacional (SPHAN), que já vinha sendo projetado e articulado pelo ministro da Educação e Saúde Gustavo Capanema desde 1936, junto a outros intelectuais, como Mário de Andrade, autor do anteprojeto de 1936, Oswaldo Teixeira e Rodrigo Melo Franco de Andrade, que assumira a direção do Serviço após sua criação. ${ }^{157}$ Barroso perdeu o protagonismo nesse processo. $\bigcirc$ que se percebeu foi um esvaziamento da IMN que, nesse ano, contou apenas com mais 50:000\$000 para suas atividades. Epaminondas de Macedo escreveria em seu relatório de 25 de julho de 1937: "por conta da dotação deste ano pouco teremos ainda que fazer [...] Dentro de um mês irei ao Rio prestar-the contas minuciosas de tudo". ${ }^{158}$

que chama a atenção, ao analisarmos a atuação da IMN, é o silêncio em relação à fiscalização e ao controle sobre o comércio de antiguidades e em torno do registro dos objetos, principal tônica do seu regulamento. No período de funcionamento da Inspetoria, não houve aumento das coleções do Museu com objetos apreendidos por infração dos dispositivos do regulamento, nem pelo direito que o MHN tinha de preferência na compra de antiguidades a serem negociadas. Mas foram acrescidas por objetos trazidos das construções restauradas em Ouro Preto e doadas pelo próprio Barroso, como um oratório portátil e duas esculturas de pombas cavalgadas por anjinhos atribuídas a Aleijadinho, oriundos da lgreja das Mercêsde Baixo (Figuras 13 e 14). Tais objetos juntaram-se a outros também recolhidos em Ouro Preto desde que Barroso iniciou ali sua campanha preservacionista, como uma pedra do Morro da Queimada, a aldrava da Casa de Marília de Dirceu, uma coroa e um cetro da Festa do Divino, uma coroa e um cetro de Congada, os artefatos ofertados por Odorico Neves, e um sinete da
154. Ver Museu Histórico Nacional (1936, p. 1-3).

155. Ver Adolpho Dumans (1947, p. 54-58).

156. Os relatórios originais enviados por Epaminondas de Macedo podem ser encontrados na pasta Inspetoria de Monumentos Nacionais. Arquivo Institucional do Museu Histórico Nacional. Foram reproduzidos em Museu Histórico Nacional (1944, p. 125-166). Os monumentos contemplados pela ação da IMN e citados em relatórios de Epaminondas de Macedo, publicados no volume 5 dos Anais do MHN foram os seguintes: Igreja de N. S. do Carmo, Igreja Matriz de N. S. da Conceição de Antônio Dias (Matriz de Antônio Dias), Igreja do Rosário, Capela do Padre Faria, Capela da Piedade, Igreja de S. Francisco de Assis, Igreja das Mercês de Baixo, Capela de São João e Capela de Sant'Ana. Chafariz dos Contos, Chafariz dos Cavalos, Chafariz do Passo de Antônio Dias, Chafariz de Marília, Chafariz da Rua da Glória, Chafariz da praça Tiradentes, Chafariz da Rua do Barão. Ponte de São José (ponte dos Contos), Ponte da Barra, Ponte do Rosário, Ponte do Padre Faria.

157. Ver Márcia Chuva (2009, p. 124-1420).

158. Cf. Relatório em 25/07/1937. Apud. Museu Histórico Nacional (1944 /1955, p. 166). 
159. Todos os objetos ficaram expostos nas galerias do MHN. As pinturas de Hans Nobauer, por exemplo, ocuparam as paredes da sala d. João VI, reforçando a ideia de ligação da História de Ouro Preto com a gênese de um Estado Nacional a partir da transferência da Corte portuguesa para o Brasil, em 1808. Cf. Museu Histórico Nacional (1955).

160. Cf. Ministério da Educação e Saúde (1946, p. 28). primeira sede do Banco do Brasil na cidade. Não podemos esquecer a coleção de imagens da cidade em tela e papel realizados por Norfini, Nobaver e Wasth Rodrigues que também contribuíram para o aumento do acervo museológico. Ouro Preto ganhava ainda mais espaço na história do Brasil narrada nas exposições. ${ }^{159}$

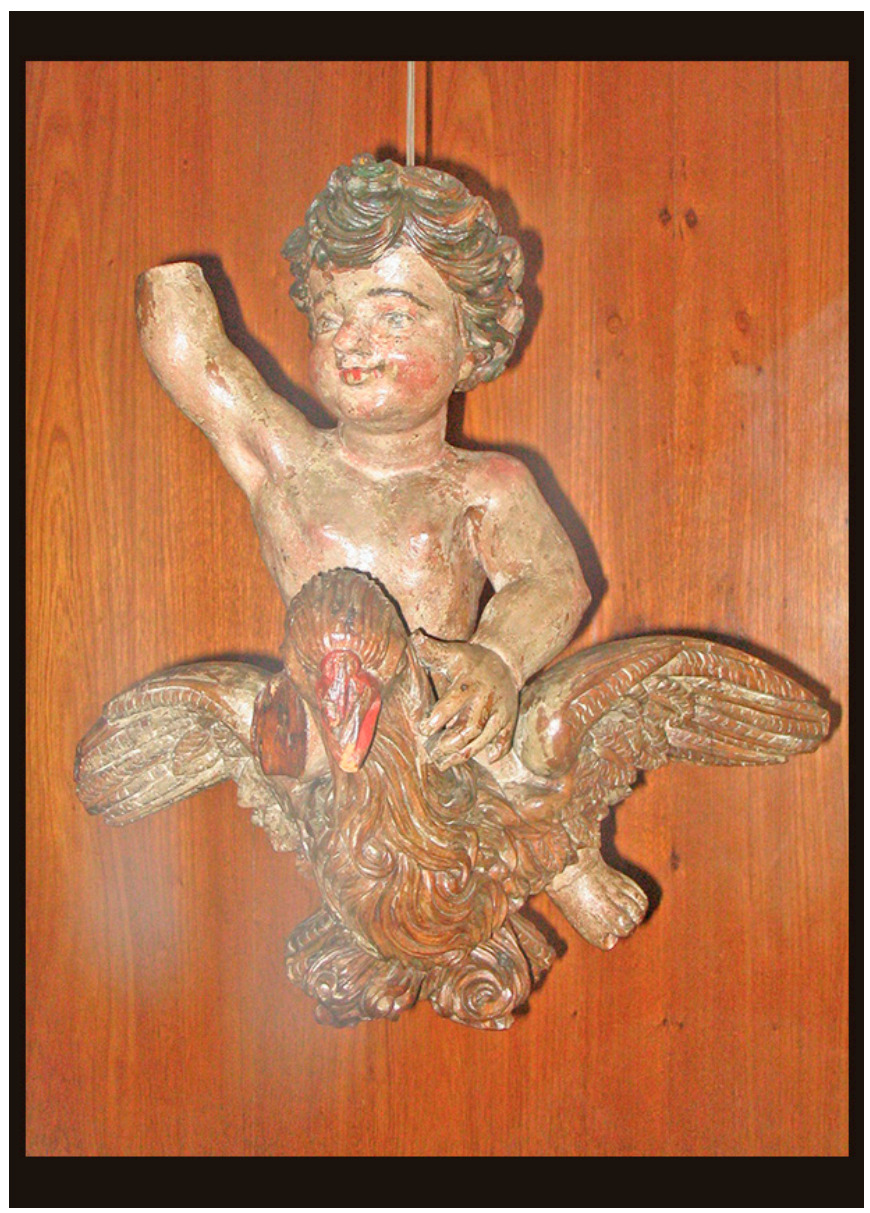

Figura 13 - Anjo cavalgando em uma pomba, atribuído a Aleijadinho. Oriundo da lgreja das Mercês de Baixo, foi dado por Gustavo Barroso ao MHN. Fotografia da autora. Acervo do Museu Histórico Nacional, Rio de Janeiro.

Os relatórios não mencionam nenhuma ação de fiscalização, peritagem nem de autenticação de objetos de colecionadores ou negociantes. Tampouco o trabalho de elaboração de catálogos, seja de objetos ou de "edifícios de assinalado valor e interesse artístico-histórico existente no país"; neste caso, para que fosse proposto ao Governo Federal o título de Monumentos Nacionais. ${ }^{160} \mathrm{~A}$ rotina do MHN quase não sofreu alteração em função das atribuições que the foram conferidas no regulamento de 1934.

O que se percebe é que a IMN atuou na área em que seu regulamento menos a amparava, deixando de lado as ações determinadas no documento e que 


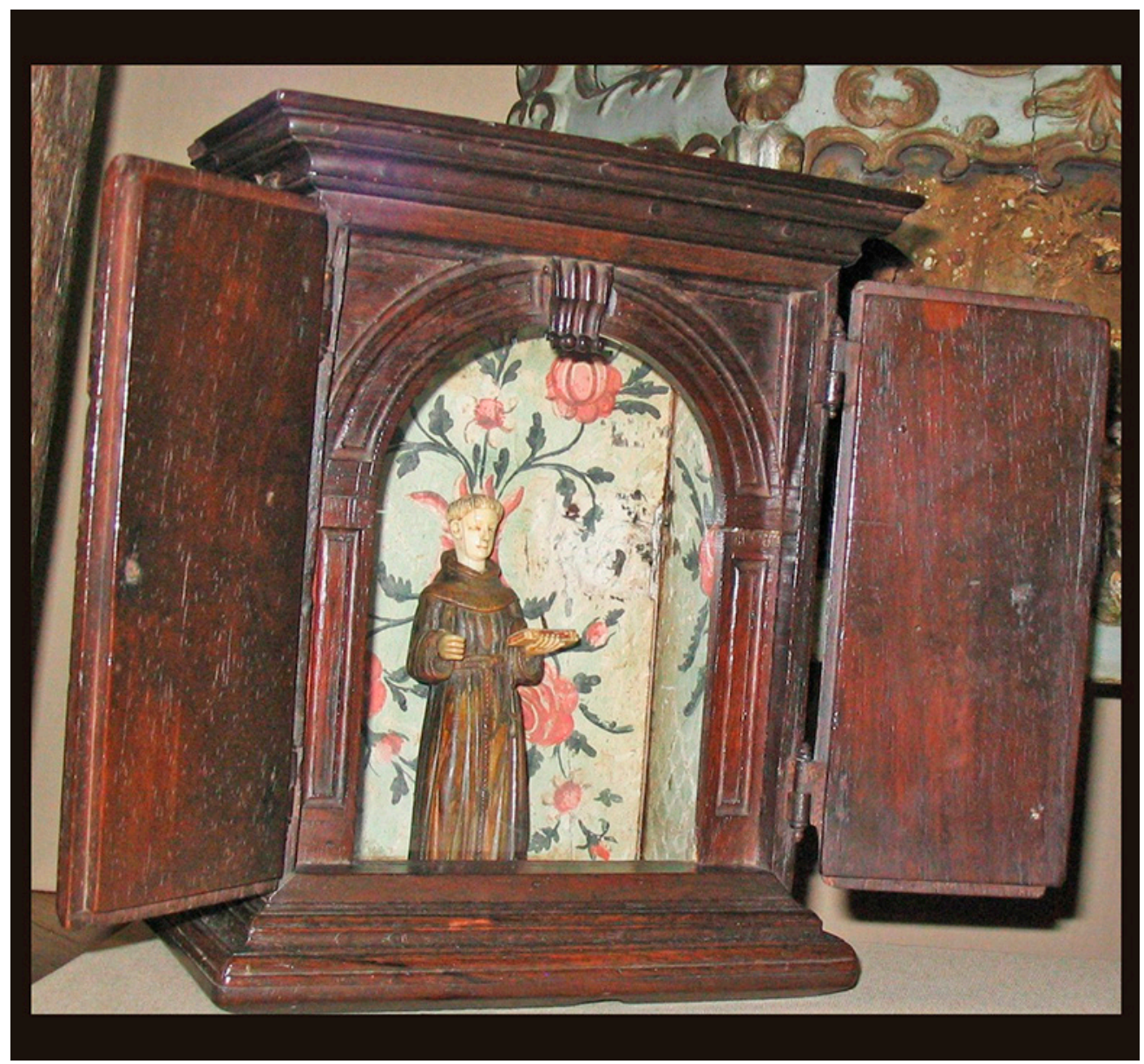

161. Cf. Rodrigo Melo Franco de Andrade (1952, p. 53).

Figura 14 - Oratório portátil, também conhecido como esmoler, por ter um espaço para depósito de doações. Pertenceu à lgreja das Mercês de Baixo. Doado por Gusatvo Barroso ao Museu Histórico Nacional. Fotografia da autora. Acervo do Museu Histórico Nacional, Rio de Janeiro.

estariam mais afinadas com as atividades concernentes a um museu, podendo, inclusive, aumentar seu prestígio e reforçar sua autoridade no campo do conhecimento sobre antiguidades. Rodrigo Melo Franco de Andrade assinalou a incoerência entre o que se previu legalmente e o que foi praticado pela instituição: "A administração federal principiara até a executar reparos e restauros de edificações coloniais em Ouro Preto [...] por intermédio do Museu Histórico Nacional, embora o regulamento deste não the conferisse atribuições para tais empreendimentos." 161

O que se pode inferir sobre a inoperância da Inspetoria junto ao comércio de antiguidades e na valoração e autenticação de objetos no sentido de classificálos como monumentos é que o regulamento do MHN foi insuficiente para promover 
162. Ver Pierre Bourdieu (2011). uma mudança no habitus ${ }^{162}$ dos agentes que lidavam com as artes e as antiguidades, bem como com a própria produção do passado nacional a partir de seus vestígios de "notável valor". Por mais que o documento parecesse frágil em seus dispositivos e a Inspetoria tivesse funcionado por pouco tempo, essas razões são bastam para explicar sua ausência nas atividades previstas no regulamento. A justificativa mais plausível e aceita é a de que o capital político de Gustavo Barroso não era suficiente para fazer do Museu Histórico Nacional uma peça fundamental da engrenagem que movia o mercado das artes e antiguidades e as redes de colecionadores no Brasil, o que era esperado a partir do regulamento. Afinal, quando Barroso solicitou ao MES que interviesse no projeto que havia sido enviado para seu parecer, pediu para sugerir outras ideias, preocupado também com as "opiniões dos interessados na parte que se refere aos proprietários de objetos históricos e artísticos". Não conseguiu, porém, promover o reconhecimento do $\mathrm{MHN} / \mathrm{IMN}$ nesse campo como autoridade para determinar o que era e o que não era autêntico, "de notável valor". De fato, havia outras autoridades já reconhecidas que exerciam o mesmo papel fora da esfera do Estado. Esses agentes, embora se relacionassem com o MHN, negociando, doando objetos e trocando saberes, parecem não ter se submetido para solicitar registro ou autenticidade de seus objetos, a exemplo de antiquários como Francisco Marques dos Santos e Leone Ossovigi, bem como de colecionadores particulares como Guilherme Guinle.

A presença da Inspetoria em Ouro Preto pode ser vista como decorrência da necessidade de o Governo Federal intervir na cidade após a concessão do título de Monumento Nacional, justificando o intermédio da IMN como única forma de atendê-la naquele momento. Tal circunstância favorecia os interesses de Gustavo Barroso em angariar projeção e reconhecimento para o Museu Histórico Nacional, ampliando seu raio de atuação e autoridade. Afinal, a cidade mineira estava no centro das atenções e suas reformas poderiam ser vistas como uma iniciativa pioneira, uma forma de atrair a atenção de diferentes grupos e autoridades para - Museu Histórico Nacional, que contava em agir na preservação de outros centros urbanos, começando por Minas.

Enfim, desde o primeiro ano de funcionamento da repartição nada se tratou a respeito do comércio de antiguidades e da catalogação de objetos artísticos e históricos. Todos os esforços foram empregados na restauração e conservação de monumentos ouro-pretanos. Vide a compra e encomenda de iconografias de Ouro Preto e outras "cidades históricas", respondendo também à pressão dos que ansiavam por cuidados na única cidade elevada a monumento nacional.

Teria sido esse descompasso entre a letra e a ação um dos motivos da falência da Inspetoria? Segundo Márcia Chuva, a justificativa para o fim da IMN 
estaria na "vertente tradicionalista de Barroso [que] não detinha capital político suficiente no contexto em que [a preservação do patrimônio] foi tornada hegemônica pelo grupo de Capanema", 163 mesmo Barroso tendo mantido seu prestígio na direção do $M H N$, onde acabou por conquistar autoridade no campo museológico e manter um diálogo direto com o presidente Vargas que contribuía, às vezes, pessoalmente para o desenvolvimento do Museu, para o aumento de suas coleções e o reconhecimento da sua autoridade. ${ }^{164}$

Assim, identificamos, na Inspetoria, um capítulo da trajetória do MHN no jogo das políticas públicas levadas a cabo no Estado varguista, para uma nova construção da ideia de nação a partir do seu passado. Foi possível analisar e inferir como Gustavo Barroso participou da história das definições do que deveria ou não ser considerado patrimônio tradicional do Brasil e como atuou a partir dessas (in)definições, imprimindo uma narrativa sobre a história do Brasil a partir do que foi selecionado para ser preservado em Ouro Preto, mas não conseguindo ter nenhuma ingerência sobre o mercado das artes e antiguidades, tampouco dos objetos de coleções particulares.

\section{A PELEJA CONTRA O ESQUECIMENTO}

Já é tempo do Museu Histórico Nacional documentar, para conhecimento público e perpétua memória da verdade, sua constante e devotada atenção na defesa do patrimônio histórico e artístico do país e no culto de sua tradição. ${ }^{165}$

As palavras que abrem o quinto volume dos Anais do Museu Histórico Nacional advertem para sua função junto aos leitores: dar subsídios à lembrança do que estaria esquecido - ou quando lembrado, mal falado. A maior parte do periódico é dedicada a um dossiê completo das atividades da Inspetoria de Monumentos Nacionais, reproduzindo correspondências, relatórios e fotografias que documentam os trabalhos de restauração realizados em Ouro Preto. Embora o volume seja uma das principais fontes de informações sobre a efêmera existência da IMN, não foi o único meio dedicado a registrar o papel de Gustavo Barroso, como diretor do $M H N$, nos projetos de defesa dos monumentos do Estado, especialmente durante os governos de Getúlio Vargas. Outras páginas do mesmo periódico foram escritas com essa função memorialística, dando ênfase às ações da IMN. Além de artigos citados ao longo deste trabalho, como "Forca de Tiradentes" e "A defesa do nosso passado", publicados nas edições de 1941 e 1943 respectivamente, vale atentar para o sétimo volume dos Anais, de 1953, inteiramente dedicado à divulgação das aquarelas e desenhos de Alfredo Norfini com comentários de Barroso. Em alguns comentários sobre as paisagens,
163. Cf. Márcia Chuva (2009, p. 134).

164. Ver Márcia Chuva (2009, p. 134). Ver também. Daryle Williams (1997, p.141-186) e Aline Montenegro Magalhães (2009, p. 140-199).

165. Cf. Museu Histórico Nacional (1944, p. 5) 
166. Cf. Museu Histórico Nacional (1953, p.24).

167. Ver Cláudia Damasceno Fonseca (2011, p. 32 e 39)

168. Ver Reinhart Koselleck (2014. p. 63-72).

169. Ver Aline Montenegro Magalhães (2009)

170. Ver Gilberto Velho (2004; 2003). edificações e outros registros publicados, há referência às ações de Barroso junto aos monumentos, a exemplo deste que acompanha a reprodução de um bico de pena representando a lgreja do Rosário:

O desenho salienta admiravelmente as linhas curvas do templo. Há dois com essa mesma planta em Minas Gerais: a do Rosário em Ouro Preto e a de São Pedro em Mariana.

Deve-se a construção desse belo e majestoso templo, em grande parte, senão totalmente, aos humildes escravos da mineração, que, para isso, davam o ouro que podiam adquirir trabalhando além das horas a que eram obrigados.

A galié da igreja era fechada por grades e sarrafos de madeira. Em 1928, o Dr. Gustavo Barroso, por conta do Governo de Minas, restaurou a igreja e pôs nesses arcos grades de ferro no estilo próprio da época. 166

Esses escritos produzidos na década de 1940, simultaneamente memoriais e celebrativos, são indícios de uma tomada de consciência da derrota vivenciada por Barroso frente à criação e ascensão do SPHAN, a partir de 1937. Nesse momento, Barroso também parecia dar-se conta do fracasso de seu projeto político integralista, limitando sua liderança frente aos projetos de produção do passado nacional aos muros do MHN. Percebia que, em seus projetos de Brasil no campo políitico, fora perdedor, como também vencida estava sua atuação na produção de uma escrita da história do Brasil edificada, que tinha em templos, pontes e chafarizes, escolhidos para receber os cuidados da INM, os marcos oficiais do tempo dos vice-reis, de uma urbanização desenvolvida sob o controle da metrópole. ${ }^{167}$ Metrópole à qual Barroso procurava ligar - Brasil com "laços imperecíveis", como já fazia nas galerias do Museu Histórico Nacional desde sua fundação, em 1922.

Inspirados nos estudos de Reinhart Koselleck sobre a história, 168 procuramos compreender a peleja de Barroso contra o esquecimento sublinhando, entre outras iniciativas, sua ałuação na proteção dos monumentos nacionais. $\bigcirc$ intelectual cearense vivenciava a experiência de que as coisas não aconteceram conforme planejadas e desejadas, amargando um forte sentimento de fracasso. Tratava-se de uma consciência da derrota mobilizada na escrita de memórias a respeito, no sentido de construir para si um outro lugar: o de pioneiro - e injustiçado -, que era como desejava ser lembrado.

A análise dos escritos publicados nos Anais do MHN não apenas gerou uma problematização sobre o desejo de memória e reconhecimento de Gustavo Barroso. ${ }^{169}$ Mobilizou, sobretudo, questionamentos seguidos de buscas e interpretação de outras fontes, tornando possivel a caracterização desse empreendimento barroseano na história da institucionalização do patrimônio no Brasil, seu projeto e campo de possibilidades. ${ }^{170}$ Assim, compartilhamos a oportunidade de refletir sobre uma experiência efêmera, derrotada há 80 anos. 


\section{REFERÊNCIAS}

DOCUMENTAÇÃO PRIMÁRIA

Jornais e revistas

A fundação do Instituto Histórico de Ouro Preto. Estado de Minas, Belo Horizonte, 19 set. 1931. Hemeroteca Gustavo Barroso, GB 19 - $19301^{\circ}$ Semestre a $19322^{\circ}$ Semestre. Disponível na biblioteca online do Museu Histórico Nacional <http://www.docpro.com.br/mhn/bibliotecadigital.html>. Acesso em: 18 mar. 2017.

BARROSO, Gustavo (1928). Cidades mortas do Sertão. Fon-Fon, Rio de Janeiro, 07 jan. 1928. Hemeroteca Gustavo Barroso, GB 16. Disponível na biblioteca online do Museu Histórico Nacional <http://www.docpro.com.br/mhn/bibliotecadigital.html>. Acesso em: 18 mar. 2017.

BARroso, Gustavo (1937). O Estylo Colonial. A Ofensiva, Rio de Janeiro, 07 fev. 1937. Hemeroteca Gustavo Barroso, GB 25. Disponível na biblioteca online do Museu Histórico Nacional $<$ http://www.docpro.com.br/mhn/bibliotecadigital.html>. Acesso em:22 set. 2016.

Excursão à Mariana. Fon-Fon, Rio de Janeiro, 18 set. 1926. Hemeroteca Gustavo Barroso, GB 15. Disponível na biblioteca online do Museu Histórico Nacional <http://www.docpro.com. br/mhn/bibliotecadigital.html>. Acesso em: 18 mar. 2017.

Inspetoria de Monumentos Nacionais. A Voz de Ouro Preto, Ouro Preto, 29 dez. 1935. Acervo: Arquivo Institucional do MHN. Pasta: Inspetoria de Monumentos Nacionais.

João do Norte (1911). Museu Militar. Apud. DUMANS, Adolpho. A ideia de criação do Museu Histórico Nacional. Anais do Museu Histórico Nacional, Rio de Janeiro, v. 3, p. 384-387, 1942.

João do Norte (1912). O culto da saudade. Anais do Museu Histórico Nacional, Rio de Janeiro, v. 29, p.32-34,1997.

João do Norte (1921). Arquitetura Nacional. Anais do Museu Histórico Nacional, Rio de Janeiro, v. 3, p. 455-465, 1942. 
João do Norte (1926). Supra Montem. Folha da Noite, São Paulo, 21 set. 1926. Hemeroteca Gustavo Barroso, GB15 Biblioteca do Museu Histórico Nacional. Disponível na biblioteca online do Museu Histórico Nacional <http://www.docpro.com.br/mhn/bibliotecadigital.html>. Acesso em: 18 mar. 2017.

João do Norte (1927). Lendas de cidades mortas. Folba da Manhã, São Paulo, 21 abr. 1927. Hemeroteca Gustavo Barroso, GB15.Biblioteca do Museu Histórico Nacional. Disponível na biblioteca online do Museu Histórico Nacional < http://www.docpro.com.br/mhn/bibliotecadigital.html>. Acesso em: 20 mar. 2017.

João do Norte (1928a). As igrejas de Minas e a Sé Velha da Bahia. Correio da Manhã, 26 jul. 1928. Hemeroteca Gustavo Barroso, GB16.Disponível na biblioteca online do Museu Histórico Nacional <http://www.docpro.com.br/mhn/bibliotecadigital.html>. Acesso em 20/03/2017.

João do Norte (1928b). Ouro Preto, cidade sagrada. Correio da Manhã, 3 nov. 1928. Hemeroteca Gustavo Barroso, GB16.Disponível na biblioteca online do Museu Histórico Nacional <http://www.docpro.com.br/mhn/bibliotecadigital.html>. Acesso em 20/03/2017.

João do Norte (1928c). A casa de Marília. Correio da Manhã, Rio de Janeiro, 15 nov. 1928.

Limpar fachadas. Fon-Fon, Rio de Janeiro, 23/04/1921. Coleção de recortes Hemeroteca Gustavo Barroso, GB 08. Biblioteca do Museu Histórico Nacional. Disponível na biblioteca online do Museu Histórico Nacional <http://www.docpro.com.br/mhn/bibliotecadigital.html>. Acesso em 1823/03/2017.

Por que escolheu o pseudônimo? A Manhã, Rio de Janeiro, 23/10/1949. Hemeroteca Gustavo Barroso, GB29.Disponível na biblioteca online do Museu Histórico Nacional <http://www. docpro.com.br/mhn/bibliotecadigital.html>. Acesso em 20/03/2017.

Documentos de arquivos

A Placa (1921). Coleção do Instituto Histórico, lata 341, pasta 46, IHGB.

BARroso, Gustavo (1933). Parecer. "C.L. 20/06/1933 XXII, Annexe - Société des Nations: ORGANISATION DE COOPERATION INTELLECTUELLE - Projet de Convention Internationale et de Repatriement des objets d'intérêt artistique, historique ou scientifique, perdus ou volés, ou ayant donne lieu a une alienation ou exportation illicite." Enviado ao Diretor Geral do Expediente do Ministério da Educação e Saúde Pública. Série Correspondências enviadas do Arquivo Institucional do Museu Histórico Nacional. ASDG2. 
BARROSO, Gustavo (1935a). Carta a Marco Túlio Gramiglia. Rio de Janeiro, 26 nov. 1935. Arquivo Institucional do Museu Histórico Nacional. Catálogo geral, série AS/DG2.

BARROSO, Gustavo (1935a). Ofício 55. Resposta de Gustavo Barroso a Eponina Ruas. 18/03/1935. Arquivo Institucional do Museu Histórico Nacional. Catálogo geral, série AS/DG2.

CELSO, Afonso (1921). Carta ao Presidente Epitácio Pessoa com cópia para o Presidente de Minas Gerais e o Presidente da Câmara Municipal de Ouro Preto. Rio de Janeiro,22 dez.1921. Coleção Instituto Histórico, lata 341, pasta 46, IHGB.

COMITÉ INTERNATIONAL DES SCIENCES HISTORIQUES. Ofício de 7 abr. 1930. Arquivo Institucional do Museu Histórico Nacional, Série Correspondências, catálogo geral, ASDG2.

GRAMigliA, Marco Túlio. Carta da Venerável Ordem Terceira da Penitência de São Francisco de Assis a Gustavo Barroso, diretor da Inspetoria de Monumentos Nacionais, 17 nov. 1935. Arquivo Institucional do Museu Histórico Nacional. Catálogo geral, série AS/DG2.

Instituto Histórico de Ouro Preto. Ofício 892 do para Museu Histórico Nacional, Ouro Preto, 18 nov. 1935. Arquivo Institucional do Museu Histórico Nacional. Catálogo geral, série AS/DG2.

MINISTÉRIO DA EDUCAÇÃO E SAÚDE PÚBLICA (1934). Ofício 242. De: Washington Pires (Ministro do MES) para: Gustavo Barroso (Diretor do MHN). Comissão Internacional dos Monumentos Históricos. 4 jun. 1934. Série Correspondências recebidas do Arquivo Institucional do Museu Histórico Nacional, ASDG2.

MINISTÉRIO DA EDUCAÇÃO E SAÚDE. Museu Histórico Nacional: Legislação. Serviço de documentação. Folheto n. 46. 1946.

MINISTÉRIO DA JUSTIÇA E NEGÓCIOS INTERIORES (1922). Ofício n. 3292 ao IHGB, 31 mar. 1922. Coleção Instituto Histórico, lata 341, pasta 46, IHGB.

MUSEU HISTÓRICO NACIONAL (1934a). Ofício n. 88. De: Gustavo Barroso. Ao Diretor Geral do Expediente do Ministro da Educação. 05 jun. 1934. Arquivo Institucional do Museu Histórico Nacional. Série Correspondências Enviadas. ASDG2.

MUSEU HISTÓRICO NACIONAL (1934b). Ofício n. 75. De Gustavo Barroso. Ao Diretor Geral do expediente do Ministério da Educação e Saúde Pública. 31 mai. 1934. Arquivo Institucional do Museu Histórico Nacional. Série Correspondências Enviadas, ASDG2. 
MUSEU HISTÓRICO NACIONAL. Ofício 64 do Museu Histórico Nacional para o Ministério da Educação e Saúde Pública, Rio de Janeiro, 23 mar. 1935. Arquivo Institucional do Museu Histórico Nacional. Catálogo geral, série AS/DG2.

MUSEU HISTÓRICO NACIONAL. Relatório de atividades de 1934. Arquivo Institucional do Museu Histórico Nacional. Série ASDG1.

MUSEU HISTÓRICO NACIONAL. Relatório de atividades de 1935. Arquivo Institucional do Museu Histórico Nacional. Série ASDG1.

MUSEU HISTÓRICO NACIONAL. Relatório de atividades de 1936. Arquivo Institucional do Museu Histórico Nacional, série ASDG1.

MUSEU HISTÓRICO NACIONAL. Relatório de atividades. 1931. Arquivo Institucional do Museu Histórico Nacional. Série ASDG1.

MUSEU HISTÓRICO NACIONAL. Relatório de atividades. 1933. Arquivo Institucional do Museu Histórico Nacional. Série ASDG1.

OLIVEIRA, D. Helvécio Gomes de, Arcebispo de Mariana (1926). Carta para Gustavo Barroso, Diretor do Museu Histórico Nacional. 07 set. 1926. Divisão de Controle do acervo do Museu Histórico Nacional. Processo 20/1926, doc. 35.

OURO PRETO. Decreto $\mathrm{n}^{\circ} 25$, de 03 de setembro de 1932. Disponível em: <http://arquivopublicoop.blogspot.com.br/2013/12/preservacao-do-patrimonio-de-ouro-preto.html>. Acesso em 26/04/2017.

OURO PRETO Decreto $\mathrm{n}^{\circ}$. 13, de 19 de setembro de 1931. Disponível em: <http://arquivopublicoop.blogspot.com.br/2013/12/preservacao-do-patrimonio-de-ouro-preto.html>. Acesso em 26/04/2017.

Processo 14/34. Divisão de Controle do Acervo do Museu Histórico Nacional.

RACIOPPI, Vicente Andrade (1930). Carta para Gustavo Barroso, Ouro Preto, 28 jun. 1930. Arquivo Institucional do Museu Histórico Nacional, catálogo geral, ASDG2,2.

RACIOPPI, Vicente. Ofício 865 de Vicente Racioppi, diretor do IHOP, para Gustavo Barroso, diretor do MHN/IMN, Ouro Preto, 01 fev. 1935. Arquivo Institucional do Museu Histórico Nacional. Catálogo geral, série AS/DG2. 
RUAS, Eponina. Carta a Gustavo Barroso. Ouro Preto, 14 mar. 1935. Arquivo Institucional do Museu Histórico Nacional. Catálogo geral, série AS/DG2.

SECRETARIA DE ESTADO DA EDUCAÇÃO E SAÚDE PÚBLICA (1934). Ofício n. 1. 903 De: Heitor de Farias. Para Gustavo Barroso. 29 mai. 1934. Arquivo Institucional do Museu Histórico Nacional. Série ASDG2.

\section{Publicações do Museu Histórico Nacional}

MUSEU HISTÓRICO NACIONAL(1944). Documentário da ação do Museu Histórico Nacional na defesa do patrimônio tradicional do Brasil. Anais do Museu Histórico Nacional, v. 5. Rio de Janeiro, 1955.

MUSEU HISTÓRICO NACIONAL. Documentário Iconográfico de cidades e monumentos do Brasil. Anais do Museu Histórico Nacional, Rio de Janeiro, v. 7, 1953.

MUSEU HISTÓRICO NACIONAL. Guia do visitante. Rio de Janeiro 1955.

\section{Páginas da rede mundial de computadores}

BRASIL. Constituição da República dos Estados Unidos do Brasil (de 16 de julho de 1934). Disponível em: http://www.planalto.gov.br/ccivil_03/constituicao/constituicao34.htm. Acesso em: 14 junho de 2012 .

Carta de Atenas. Out. 1931. Disponível em:<http://www.unisc.br/universidade/estrutura_administrativa/nucleos/npu/npu_patrimonio/legislacao/internacional/patr_cultural/cartas/atenas_1931.pdf>. Acesso em 5 de julho de 2003.

<https://pt.wikipedia.org/wiki/Diogo_Pereira_Ribeiro_de_Vasconcelos>. Acesso em 22mar.2017.

$<$ http://www.siaapm.cultura.mg.gov.br/modules/rapm/brtacervo.php?cid=19\&op=1 $>$. Acesso em 3abr.2017.

<http://roerich.org.br/portal/pacto-roerich/>. Acesso em 30/03/2016. 
AGUIAR, Leila Bianchi. Cidade morta, cidade monumento, cidade turística: a construção de memórias sobre Ouro Preto. In: CASTRO, Celso; GUIMARÃES, Valéria Lima e MAGALHÃES, Aline Montenegro (orgs). História do Turismo no Brasil. Rio de Janeiro: Editora FGV, p. 177$195,2013$.

Desafios, permanências e transformações na gestão de um sítio urbano patrimonializado: Ouro Preto, 1938 a 1975. Revista Estudos Históricos, Rio de Janeiro, v. 29, n. 57, p. 87-106, abr. 2016. Disponível em: <http://bibliotecadigital.fgv.br/ojs/index.php/reh/article/ view/59112/60266>. Acesso em: 2 jun. 2017.

ANASTASIA, Carla Maria Junho; JULIÃO, Letícia; LEMOS, Carmem Silvia. Dos bandeirantes aos modernistas: um estudo histórico sobre Vila Rica. Oficina do Inconfidência, Ouro Preto, ano 1, n. 0, p. 17-132, dez. 1999.

ANDRADE, Rodrigo Melo Franco de. Brasil: monumentos históricos e arqueológicos. Cidade do México: Instituto Pan-americano de Geografia e História / Comission de História, 1952.

BANN, Stephen. Invenções da história. Ensaios sobre a representação do passado. São Paulo: Editora da Unesp, 1994.

Romantism and the Rise of History. Nova York: Twayne Publishers, 1995.

The Clotbing of Clio. A Study of the Representation of History in Nineteenth-Century Britain and France. Cambridge: Cambridge University Press, 1984.

BARroso, Gustavo (1941). O Consulado da China. $3^{\text {a }}$ ed. Fortaleza: Casa de José de Alencar, 2000.

(1943). A defesa do nosso passado. Anais do Museu Histórico Nacional, Rio de Janeiro, v. 4, p. 379-585, 1943.

(1941). A forca de Tiradentes. Anais do Museu Histórico Nacional, Rio de Janeiro, v. 2, p. 345-349, 1941.

(1951). Introdução à técnica de museus. $2^{\mathrm{a}} \mathrm{a}$ ed., v. 1, Rio de Janeiro: Gráfica Olímpica, 1951. 
BEZERRA, Rafael Zamorano. Autoridade e função de autor na valoração de objetos históricos. $\mathrm{O}$ caso das traves da forca de Tiradentes. In: BEZERRA, Rafael Zamorano e MAGALHÃES, Aline Montenegro. Museus Nacionais e os desafios do contemporâneo. Rio de Janeiro: Museu Histórico Nacional, 2011.

BITTENCOURT, José Neves. Ouro Preto, nossa Roma. Antiquários e tradições numa trajetória de preservação. Oficina do Inconfidência, Ouro Preto, ano 5, n. 4, p. 123-137, dez.2007.

BONOMO, Mário Roberto. Ouro Preto: de relíquia mineira à glória nacional.1998. 319f. Tese (Doutorado) - Programa de Pós-Graduação do Departamento de História do Instituto de Ciências Humanas / Universidade de Brasília, Brasília, 1998.

BOURDIEU, Pierre. A distinção: crítica social do julgamento. $2^{\mathrm{a}}$ ed. Porto Alegre: Zouk, 2011.

Razões práticas: sobre a teoria da ação. Campinas: Papirus, 1996.

CANTARELLI, Rodrigo. Contra a conspiração da ignorância com a maldade: Inspetoria de Monumentos de Pernambuco. Recife: Fundação Joaquim Nabuco / Editora Massangana, 2014.

CARVAlHO, Feu. Pontes e chafarizes de Villa Rica de Ouro Preto. Belo Horizonte: Ed. Históricas; Imprensa Oficial, s.d..

CARVALHO, José Murilo. Tiradentes: um herói para a República. In: A Formação das almas: o imaginário da República no Brasil. São Paulo: Companhia das Letras, 1990. p. 55-73.

CERAVOLO, Suely Moraes. A Inspetoria Estadual de Monumentos Nacionais do estado da Bahia: do discurso à ação (1927-1938). In: MAGALHÃES, Aline Montenegro, BEZERRA, Rafael Zamorano. 90 anos do Museu Histórico Nacional em debate. Rio de Janeiro: MHN, p. 122-144, 2012.

O Museu do Estado da Bahia, entre ideais e realidades (1918 a 1959). Anais do Museu Paulista: História e Cultura Material, São Paulo, v. 19, n. 1, p. 189-246, jun. 2011. Disponível em $<$ http://www.scielo.br/scielo.php?script=sci_arttext\&pid=S0101-7142011000100007\&lng=pt\&nrm =iso>. Acesso em: 08 jun. 2017. <http://dx.doi.org/10.1590/S0101-47142011000100007>.

CERTEAU, Michel. Escrita da História. $2^{\text {a }}$ ed. Rio de Janeiro: Forense Universitária, 2000.

CHOAY, Françoise. A alegoria do patrimônio. São Paulo: Estação Liberdade: Ed. Unesp, 2001.

CHUVA, Márcia. Os arquitetos da memória: sociogênese das práticas de preservação do patrimônio cultural no Brasil (anos 1930-1940). Rio de Janeiro: UFRJ, 2009. 
DUMANS, Adolpho. A ideia da criação do Museu Histórico Nacional. Rio de Janeiro: Gráfica Olímpica, 1947.

FERREIRA, Camila Kézia Ribeiro. A história e o mito: a figura do Aleijadinho na escrita polêmica de Augusto de Lima Júnior. In: OLIVEIRA Camila Aparecida Braga; MOLLO Helena, Miranda; BUARQUE, Virgínia Albuquerque de Castro (orgs). Caderno de resumos E Anais do $5^{\circ}$. Seminário Nacional de História da Historiografia: biografia \& história intelectual. Ouro Preto: EdUFOP, 2011. Disponível em: <http://www.seminariodehistoria.ufop.br/ocs/index. php/snhh/2011/paper/viewFile/825/283>. Acesso em 2 mai. 2017.

FERREIRA, Camila Kézia Ribeiro. A polêmica como patrimônio: Augusto de Lima Júnior e a Revista de História e Arte nos embates da política patrimonial (1930-1966). 2014. Dissertação (Mestrado) - Programa de Pós-graduação em História, Universidade Federal de Ouro Preto, Ouro Preto, 2014.

FONSECA, Cláudia Damasceno. Arraiais e vilas d'el rei: espaço e poder nas Minas setecentistas. Belo Horizonte: UFMG, 2011.

GUIMARAES, Manoel Luiz Salgado. Vendo o passado: representação e escrita da história. Anais do Museu Paulista, São Paulo, v. 15, n. 2, p. 11-30, Dec. 2007.

KESSEL, Carlos. Arquitetura neocolonial no Brasil: entre o pastiche e a modernidade. Rio de Janeiro: Jauá Editora, 2008.

KOSELLECK, Reinhart. Estratos do tempo: estudos sobre história. Rio de Janeiro: Contraponto: PUC, 2014.

KÜHL, Beatriz Mugayar. A restauração de monumentos históricos na França após a Revolução Francesa e durante o século XIX: um período crucial para o amadurecimento teórico. Revista CPC, São Paulo, n. 3, p. 110-144, nov. 2006/abr. 2007.

Viollet-le-Duc e o verbete Restauração. In: VIOLLET-LE-DUC, Eugène Emmanuel. Restauração. Cotia-SP: Ateliê Editorial, 2000.

LENZI, Maria Isabel Ribeiro. O álbum As cidades do Salvador e Rio de Janeiro no século XVIII, de Gilberto Ferrez. In: MAGALHÃES, Aline Montenegro. BEZERRA, Rafael Zamorano. Os vicereis no Rio de Janeiro 250 anos. Rio de Janeiro: Museu Histórico Nacional, 2015.

MAGALHÃES, Aline Montenegro. Colecionando relíquias... um estudo sobre a Inspetoria de Monumentos Nacionais. 2004. 152f. Dissertação (Mestrado) -Programa de Pós-graduação em História Social, Universidade Federal do Rio de Janeiro, Rio de Janeiro, 2004. 
Troféus da guerra perdida: um estudo histórico sobre a escrita de si de Gustavo Barroso. 2009. 258f. Tese (Doutorado em História Social) - Programa de Pós-graduação em História Social, Universidade Federal do Rio de Janeiro, Rio de Janeiro, 2009.

MAIO, Marcos Chor. Nem Rotschild nem Trotsky, o pensamento anti-semita de Gustavo Barroso. Rio de Janeiro: Imago, 1992.

MARTINS, Alexandre (Org.). Referências: Ouro Preto em Luiz Fontana. $2^{\mathrm{a}}$ ed., Ouro Preto: UFOP, 1996.

MOREIRA, Afonsina Maria Augusto. No norte da saudade: esquecimento e memória em Gustavo Barroso. 2009. 301f. Tese (Doutorado) - Pontifícia Universidade Católica de São Paulo, São Paulo, 2009.

MOTTA, Marly Silva da. A nação faz 100 anos. Questão nacional no centenário da independência. Rio de Janeiro: Ed. da Fundação Getúlio Vargas - CPDOC, 1992.

OLIVEIRA, Alexandre Augusto de. O olhar do fotógrafo Luis Fontanta: documentação de Ouro Preto (1930-1960) -Fotografia e arte pública: um estudo de caso. 2006. Dissertação (Mestrado) - Universidade Estadual Paulista / Instituto de Artes, São Paulo, 2006.

OLIVEIRA, Lúcia Lippi. A questão nacional na Primeira República. São Paulo: Brasiliense; Brasília: CNPq 1990.

PECAULT, Daniel. Os intelectuais e a política no Brasil. Entre o povo e a nação. São Paulo: Ática, 1990.

RAMOS, Francisco Régis Lopes. Quase passado. In: A poeira do passado: tempo, saudade e cultura material. Fortaleza: Imprensa Universitária, p. 244-254, 2014.

RIEGL, Alois. O culto moderno dos monumentos. E outros ensaios estéticos. Lisboa. Edições 70, 2013. [1903].

RUAS, Eponina. Ouro Preto: sua história, seus templos e monumentos. $3^{\mathrm{a}}$ ed. Belo Horizonte, [s.n.], 1964.

Conhecendo Ouro Preto: plano de visitação e mapa da cidade. $4^{\mathrm{a}}$ ed. s/d.

RUSKIN, John. A lâmpada da memória. Cotia-SP: Ateliê Editorial, 2008. [1849]. 
SHWARCZ, Lília Moritz. O espetáculo das raças. Cientistas, instituições e questão racial no Brasil, 1870-1930. São Paulo: Companhia das Letras, 1993.

VELHO, Gilberto. Individualismo e cultura. Notas para uma antropologia da sociedade contemporânea. $7^{\mathrm{a}}$ ed. Rio de Janeiro: Jorge Zahar, 2004.

. Projeto e metamorfose. Antropologia das sociedades complexas. $3^{\mathrm{a}} \mathrm{ed}$. Rio de Janeiro: Jorge Zahar Editor, 2003.

VIOLLET-LE-DUC, Eugène Emmanuel. Restauração. Cotia-SP: Ateliê Editorial, 2000.

WILLIAMS, Daryle. Sobre patronos, heróis e visitantes. O Museu Histórico Nacional, 19301960. Anais do Museu Histórico Nacional, Rio de Janeiro, vol. 29, p. 141-186, 1997.

Vicente Racioppi: the local preservationist and the National State, In: The Human Tradition in Brazil. Peter M. Beattie, ed. Wilmington, DE: Scholarly Resources, 2003, 183205. Disponívelem: <http://faculty.history.umd.edu/DWilliams/courses/Spring06/HIST471/ Racioppi.pdf $>$. Acesso em 14/04/2017.

Artigo apresentado em 20/06/2017. Aprovado em 27/10/2017. 